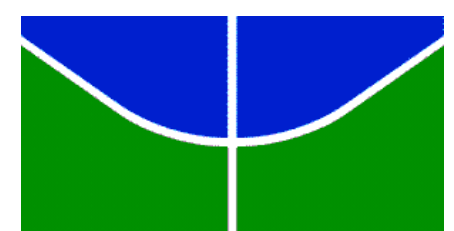

UNIVERSIDADE DE BRASÍLIA

Instituto de Ciências Biológicas

Instituto de Física

Instituto de Química

Faculdade UnB Planaltina

Programa de Pós-Graduação em Ensino de Ciências

Mestrado Profissional em Ensino de Ciências

\title{
O DESENVOLVIMENTO DOS CONTEÚDOS ATITUDINAIS E PROCEDIMENTAIS UTILIZANDO UM JOGO NO ENSINO DE ASTRONOMIA
}

ISABELLA GUEDES MARTINEZ

Brasília, DF

2014 


\section{UNIVERSIDADE DE BRASÍLIA}

\section{Instituto de Ciências Biológicas}

Instituto de Física

Instituto de Química

Faculdade UnB Planaltina

Programa de Pós-Graduação em Ensino de Ciências

Mestrado Profissional em Ensino de Ciências

O desenvolvimento dos Conteúdos Atitudinais e Procedimentais utilizando um Jogo no Ensino de Astronomia

Isabella Guedes Martinez

Dissertação realizada sob orientação da Prof. $^{\text {a }}$ Dr. ${ }^{\text {a }}$ Eliane Mendes Guimarães e coorientação do Prof. Dr. Ivan Soares Ferreira apresentada à banca examinadora como requisito parcial à obtenção do Título de Mestre em Ensino de Ciências, pelo Programa de Pós-Graduação em Ensino de Ciências da Universidade de Brasília.

Brasília, DF 
FOLHA DE APROVAÇÃO

ISABELLA GUEDES MARTINEZ

\section{O DESENVOLVIMENTO DOS CONTEÚDOS ATITUDINAIS E PROCEDIMENTAIS UTILIZANDO UM JOGO NO ENSINO DE ASTRONOMIA}

Dissertação apresentada à banca examinadora como requisito parcial à obtenção do Título de Mestre em Ensino de Ciências, pelo Programa de Pós Graduação em Ensino de Ciências da Universidade de Brasília.

BANCA EXAMINADORA

Prof $^{a}$. Dr ${ }^{a}$. Eliane Mendes Guimarães

(Presidente)

Prof. Dr. Paulo Eduardo de Brito

(Membro interno não vinculado ao Programa - FUP/UnB)

Prof ${ }^{a}$. Dr ${ }^{\mathrm{a}}$. Maria de Fátima da Silva Verdeaux

(Membro interno vinculado ao Programa - IF/UnB) 
Dedico este trabalho ao meu perfeito Deus, grandioso e único. Dedico ao meu esposo, que me auxiliou muito no processo deste trabalho, e ao meu professor e amigo Ivan que se mobilizou bastante para que o trabalho ficasse adequado. Dedico, também, à minha linda mãe e ao meu branco Gim. 


\section{AGRADECIMENTOS}

Agradeço a Deus por minha vida e minha trajetória.

Agradeço ao meu esposo e melhor amigo Jefferson por todos os momentos maravilhosos, perfeitos, conquistas em equipe, pelas boas ideias e pelo auxílio em escutar sempre minhas leituras de capítulos da dissertação.

Agradeço à minha mãe Izabel pelas histórias de vida, ensinamentos maravilhosos que me auxiliaram para definir minha personalidade e atitudes, e anéis que ela projetou me presentear em cada etapa acadêmica.

Agradeço ao meu gatinho Gim por estar comigo em todos os momentos de escrita, na cadeira, nas folhas, na mesa, no colo.

Agradeço à professora Eliane por me aceitar no mestrado e pelos ótimos momentos de interação e muito aprendizado.

Agradeço ao professor Ivan que investiu parte do seu tempo para que meu trabalho se concretizasse.

Agradeço ao professor Paulo Brito por auxiliar em uma etapa bastante importante deste trabalho, a aplicação do Jogo, e ao apoio e consideração que sempre me forneceu.

Agradeço à professora Fátima Verdeaux pelo auxílio e ensino neste mestrado, e também por ter me ajudado a crescer como professora e pessoa.

Agradeço ao professor chefe Gerson, meu grande amigo, que em outra fase da minha vida, me orienta.

Agradeço ao professor Paulo Bretones pelo apoio e cordialidade no trabalho, como também pela motivação e sucesso que teve, quanto ao nosso livro.

Agradeço pelo amor da minha avó tia Bel, pelo interesse por minha vida e trabalho.

Agradeço ao PPGEC e às pessoas que trabalham por este mestrado e que foram sempre competentes e comprometidos com o desenvolvimento do Programa.

Agradeço a todos que de alguma forma auxiliaram para que tudo ocorresse da forma devida. 


\section{RESUMO}

Neste trabalho são analisados contextos de ensino e aprendizagem, em busca de evidências da relação entre a aplicação de um jogo chamado Perfil Astronômico e as suas contribuições para o desenvolvimento de conteúdos atitudinais e procedimentais. Optou-se pelo tema da astronomia, pois este ramo do conhecimento é de natureza transdisciplinar e interdisciplinar, enquanto o jogo se mostra como um recurso didático adequado para fomentar a investigação e a aprendizagem lúdica. Os dados empíricos, categorizados em uma tabela dos conteúdos atitudinais e procedimentais criada neste trabalho, foram obtidos no decorrer de aplicações deste jogo com licenciandos em Ciências Naturais da Universidade de Brasília. Como resultado, detectou-se os desenvolvimentos pretendidos em grande parte dos participantes, inclusive no sentido de um convencimento de se utilizar ferramentas didáticas semelhantes em seu futuro cotidiano escolar como professores de ciências.

Palavras - Chave: jogo; conteúdos atitudinais e procedimentais; ensino de ciências naturais; ensino de astronomia. 


\section{RESUMEN}

En este trabajo se analizarán, en la enseñanza y en el aprendizaje, la evidencia de la relación entre la aplicación del Juego Perfil Astronómico y las contribuciones al desarrollo de los contenidos actitudinales y de los contenidos procedimentales. Fue decidido el tema de la astronomía porque esta rama del conocimiento es de la naturaleza transdisciplinaria e interdisciplinaria, mientras que el juego se muestra como fomentador de la investigación y del aprendizaje lúdico. Los datos empíricos, clasificados en una tabla de los contenidos actitudinales e procedimentales que fue hecha, fueron obtenidos en la aplicación de un juego con estudiantes del curso de licenciatura en Ciencias Naturales de la Universidad de Brasilia. Como resultado, fueron observados desarrollos por los participantes, incluyendo el efecto de la utilización de herramientas de enseñanza similares en su rutina escolar como futuros profesores de ciencias naturales.

Palabras - clave: juego; contenidos actitudinales y procedimentales; enseñanza de ciencias naturales; la enseñanza de la astronomía. 


\begin{abstract}
In this text we study the contexts of learning and teaching, looking for evidences of a relation between the application of a game, named Peril Astronomic, and its contributions to the development of attitudinal and procedimental contents. We choose the astronomy because this branch of science is, by its nature, transdisciplinary and interdisciplinary. In the other hand, the use of a game as a pedagogical approach is justified because it seems to be a correct tool to foment the inquiry and the playful learning. The empirical data, classified into a table of attitudinal and procedimental purports also created in this work, was collected during game application sections with undergraduate students of the Natural Sciences major, offered by the University of Brasilia. As a result, it was detected that the expected main developments was achieved by a large amount of participants, while we could see that some of them was convinced that this kind of tool can be effectively applied in their future as science teachers.
\end{abstract}

Keywords: game; attitudinal and procedimental contents; teaching of natural sciences; astronomy education. 


\section{LISTA DE FIGURAS}

Página

Figura 1 - Os estudantes da educação básica devem aprender Astronomia? 25

Figura 2 - Distribuição de respostas sobre a questão de se estudar Astronomia 26

Figura 3 - Distribuição relativa de professores que participaram de cursos de Astronomia ao longo da sua formação 26

Figura 4 - Professores que ensinam Astronomia em sala de aula 27

Figura 5 - Porcentagem de professores, por região, que ensinam Astronomia 28

Figura 6 - Complementação das aulas de Astronomia 28

Figura 7 - Porcentagem das respostas da questão: já visitou sites procurando atividades para desenvolver junto aos alunos? $\quad 30$

Figura 8 - Porcentagem das respostas para a questão: já experimentou o lúdico e jogos em sala de aula? 31

Figura 9 - Há tempo e espaço ao longo do ano letivo para que sejam desenvolvidos jogos e atividades lúdicas? 32

Figura 10 - Tabuleiro do Jogo Perfil Astronômico 45

Figura 11 - Opção de tabuleiro do Jogo Perfil Astronômico 45

Figura 12 - Opção de tabuleiro do Jogo Perfil Astronômico Fonte: Bretones (2013) 45

Figura 13 - Exemplo de carta do Jogo Perfil Astronômico, da classificação Instrumento Fonte: Bretones (2013) 46

Figura 14 - Semestre de ingresso dos licenciandos - diurno $\quad 65$

Figura 15 - Semestre de ingresso dos licenciandos - noturno $\quad 65$

Figura 16 - Vantagens do Jogo Perfil Astronômico - diurno 66

Figura 17 - Vantagens do Jogo Perfil Astronômico - noturno 66

Figura 18 - Vantagens vespertino + noturno 66

Figura 19-Conteúdos Procedimentais - diurno $\quad 67$

Figura 20 - Conteúdos Procedimentais - noturno $\quad 68$

$\begin{array}{ll}\text { Figura } 21 \text { - Conteúdos Atitudinais - diurno } & 69\end{array}$

$\begin{array}{ll}\text { Figura } 22 \text { - Conteúdos Atitudinais - noturno } & 69\end{array}$

$\begin{array}{ll}\text { Figura } 23 \text { - Conteúdos Conceituais - diurno } & 70\end{array}$

Figura 24 - Conteúdos Conceituais - noturno $\quad 70$

Figura 25 - Vantagens do Jogo Perfil Astronômico - diurno 72

Figura 26 - Vantagens do Jogo Perfil Astronômico - noturno 74

Figura 27 - Desvantagens do Jogo Perfil Astronômico - diurno 76 
Figura 28 - Desvantagens do Jogo Perfil Astronômico - noturno

Figura 29 - Aprenderam com o Jogo Perfil Astronômico?

Figura 30 - Interação do grupo

Figura 31 - Busca de informações em diferentes recursos

Figura 32 - Registros das informações das dicas das cartas 


\section{LISTA DE TABELAS}

Página

Tabela 1 - Focos da pesquisa em Ensino de Astronomia

Tabela 2 - Tabela de categorias - Conteúdos Atitudinais e Procedimentais do Ensino de Ciências

Tabela 3 - Conteúdos Atitudinais 84

Tabela 4 - Conteúdos Procedimentais 88 


\section{SUMÁRIO}

Página

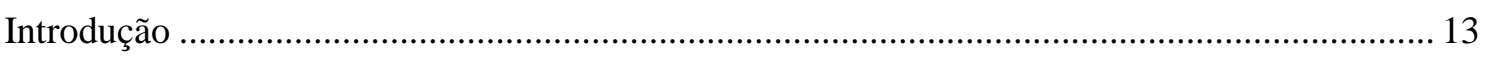

1 Estado da arte - breve revisão na área de astronomia nos últimos doze anos....................... 18

2 O uso de recursos didáticos por professores do ensino de astronomia no Brasil: o que pensam os professores relacionados ao OBA ……............................................................ 24

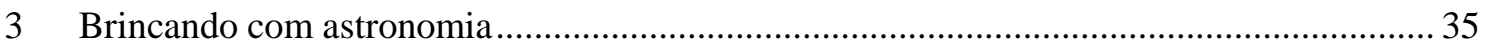

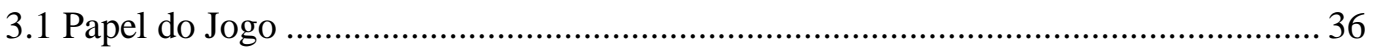

3.2 Alguns jogos existentes que podem ser utilizados na área de ensino de astronomia 40

3.2.1 História do emprego do Jogo Perfil Astronômico .................................................... 42

3.2.2 Descrição do Jogo Perfil Astronômico....................................................................... 44

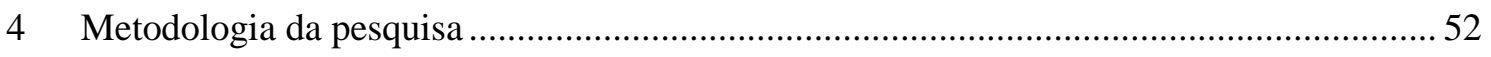

4.1 Conteúdos conceituais, atitudinais e procedimentais .............................................. 52

4.2 Categorias de Conteúdos Atitudinais e Procedimentais no Ensino de Astronomia .. 55

4.3 Como foi a pesquisa - Local da pesquisa e público alvo............................................ 57

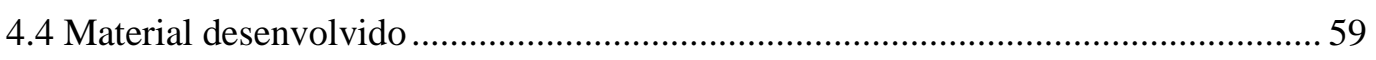

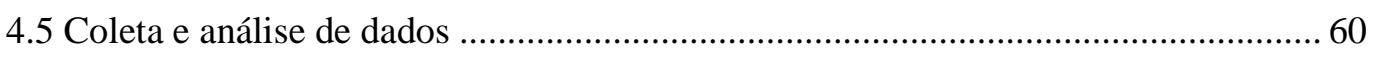

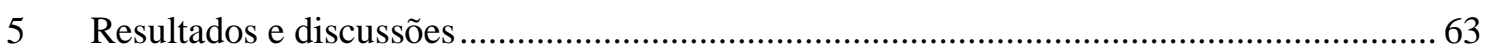

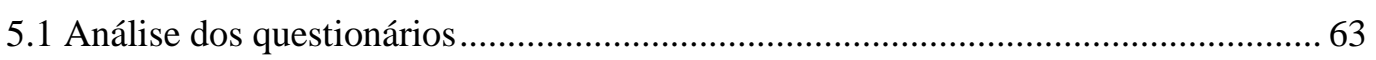

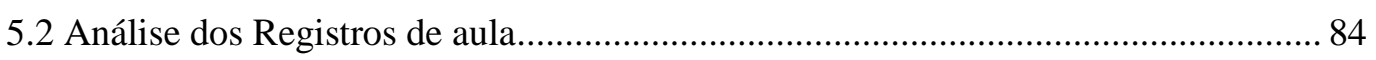

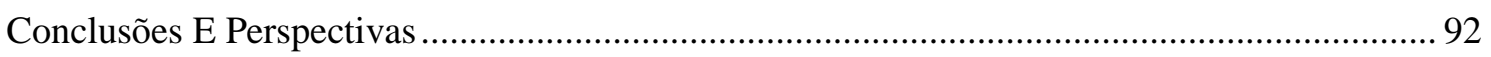

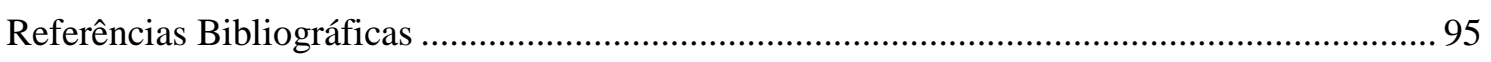

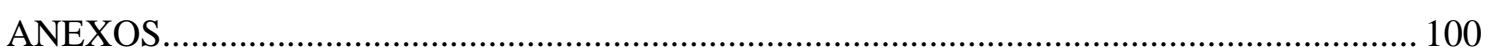

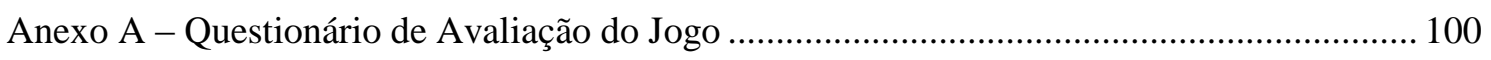

Anexo B - Termo de Consentimento Livre e Esclarecido............................................................... 103 
Todos os dias quando acordamos, celebramos a vida, o ar que respiramos, o alimento que nos nutre. Entretanto, para além da vida, o questionamento de onde ela vem, o que compõe os alimentos e o ar, o que é a energia, o que é a origem do tudo, persiste no cerne de todos nós. Talvez a inspiração para estas respostas esteja na ciência mãe, a excelsa astronomia.

(Isabella Guedes e Jefferson Moreira) 


\section{INTRODUÇÃO}

Há diversas razões para se admirar a ciência. Primeiro porque ela explica o mundo, o funcionamento das coisas, e depois porque fornece o alicerce para todo o desenvolvimento tecnológico. Outra razão está no seu método, pois ao exigir um pensamento crítico do pesquisador, alavanca o mesmo tipo de pensamento de outros membros da sociedade e isso traz benefícios incomensuráveis.

Suportado por esses benefícios, e objetivando formar pessoas que olhem cientificamente para o mundo que os cerca, nasce o ensino de ciências. Esse ensino, voltado para trabalhar as atitudes, fomentar o debate nas mais diferentes situações e empreender a investigação do meio que cerca a cada um, possibilita ao aluno o poder do discernimento.

Mas o ensino de ciências aqui tratado fala de quais ciências? Aqui a ciência é representada pela Física, Astronomia, Química, Biologia, Geologia e outras áreas. Este texto é focado na Astronomia, pois é uma área que desde a sua origem conecta os outros ramos da ciência, assim como gera bastante curiosidade por parte dos alunos.

A Astronomia é considerada o primeiro conhecimento humano organizado de forma sistemática (MOURÃO, 2008). Dentre seus objetos de estudo estão presentes as galáxias, as estrelas, até chegar aos planetas e aos corpos menores do nosso Sistema Solar, como luas, asteroides e cometas. Possui uma história que remonta aos primeiros momentos da civilização e ao domínio do meio ambiente. E assim, a Astronomia seguiu sempre ao lado dos grandes desenvolvimentos tecnológicos, ainda mais do renascimento até a contemporaneidade.

Como exemplo desta participação da Astronomia no cotidiano, temos:

$\mathrm{Na}$ vida, quase tudo parece depender das estrelas. Ou melhor, tudo em nossas vidas depende efetivamente de um desses corpos celestes: o Sol, nossa estrela central. Basta lembrar que a vida existe, porque existe a luz do Sol. Apesar disso, muitas vezes, imaginamos que as estrelas, sempre cantadas em prosa e versos, servem apenas para alimentar nossos sonhos. Conhecer como nascem, vivem e morrem as estrelas é conhecer como surge a luz, bem como tudo aquilo que dá origem e serve de sustentação à vida. Essas questões, portanto, ligam a natureza do universo às próprias raízes da gênese humana. (IVANISSEVICH, A. et al. 2010, p.20) 
O olho do ser humano, desde o início das observações do céu, foi a ferramenta de registro de muitos fenômenos astronômicos e, depois, o telescópio, que pode ser entendido como criação do homem tendo a Astronomia como inspiração. Nota-se, com o desenvolvimento do conhecimento humano e com a criação de recursos para auxiliar na área de astronomia, que ocorreu e pode ocorrer a amplificação de conhecimentos.

Ivanisevic, A. et al. (2010) afirmam que "a observação e nomenclatura dos céus, adotadas até hoje pela civilização ocidental, remontam aos babilônios, egípcios, gregos e romanos" (p.21). Então, observar o céu tem história na sociedade, e devido a estas miradas para ele, "como o olho foi a principal ferramenta de registro das observações astronômicas desde seu início até a metade do século 19, não é surpresa que os maiores desenvolvimentos tecnológicos tenham sido em telescópios ópticos." (IVANISSEVICH, A. et al. 2010, p.31).

Ainda sobre os artefatos da Astronomia, o calendário é uma construção memorável. Os primeiros calendários tinham propósitos astronômicos e astrológicos. Pessoas localizavam-se e viviam em função da ordem das estrelas. Época de chuva ou época de seca pode ser prevista por meio da posição das estrelas. Referente ao calendário, seu estudo pôde ser desenvolvido ao longo da história, e foi importante para o desenvolvimento da astronomia.

Pode-se dizer que esta ciência, a Astronomia, progrediu positivamente, de forma inter-relacionada. Para a compreensão do Universo, do Sistema Solar e do planeta Terra, por exemplo, a Astronomia integra conhecimentos de diversas disciplinas, o que a torna uma ciência transdisciplinar e também interdisciplinar. Referente ao conceito interdisciplinar há uma relação entre os conteúdos, como os das ciências, e esse fato pode auxiliar na base para se formar novos conhecimentos.

Por meio do estudo desta área, pode-se desenvolver alguém com capacidades de reflexão e criticidade. Segundo Carvalho (2008):

...mesmo que seja reconhecida sua prática na ecologia, na cosmologia, nas ciências da terra e da cognição, a transdisciplinaridade não sepulta a figura do especialista, o que seria algo insensato, mas aposta na formação de educadores sistêmicos, polivalentes, abertos, mestiços, reflexivos, críticos, amorosos, utópicos. Com estas características, a astronomia se torna um conteúdo curricular com grande possibilidade de desenvolver, nos estudantes, uma visão integrada da ciência. No estudo da astronomia é possível inter-relacionar as diversas áreas do conhecimento, de forma natural. (Carvalho, 2008, p. 04) 
Até o final do Renascimento, a astrologia foi uma atividade essencialmente acadêmica, exercida inclusive por médicos. Tycho Brahe (1546-1601), o alemão Johannes Kepler (1571-1630) e o italiano Galileu Galilei (1564-1727) foram também astrólogos, nos sentidos definidos por Nicolas Oresme (1320-1382) como astrologia matemática (astronomia) e astrologia natural (relacionada com a física e depois chamada de astrofísica). Hoje, a astronomia está muito mais difundida.

Neste trabalho lidaremos com a astronomia, não só como uma disciplina do ensino de ciências, mas principalmente como uma ferramenta para discutir ciências, construção de conhecimento e métodos de ensino e de aprendizagem.

Pessoas aprendem e podem imitar o que aprenderam e/ou criar ou inovar alguma informação a partir do que está formalizado em sua estrutura de aprendizado. Pensar de nova maneira, exercendo o papel de uma pessoa com atitudes em relação à ciência e com capacidades de interpretar, analisar, compreender uma informação, necessita uma aprendizagem e um desenvolvimento da estrutura formada no indivíduo.

Com base no que defende Soares (2008) a respeito de a aprendizagem estar fundamentalmente ligada ao saber ou ao adquirir algum tipo de conhecimento, pode-se observar a possibilidade de um indivíduo desenvolver este aprendizado por meio de um jogo. Considerando que o jogo pode incentivar estas ações, e pode ter um caráter cognitivista e que pode estimular não só a diversão e a competição, mas também o trabalho colaborativo e investigativo acerca de um tema, é importante perceber sua grande valia no contexto de ensino e aprendizagem.

Um jogo pode atender às demandas acima mencionadas? Para responder esta questão, pesquisamos o Jogo Perfil Astronômico, criado pela autora, e o seu papel no desenvolvimento do pensamento, em seus aspectos atitudinais e procedimentais, além dos conceituais, para seu uso posterior nas séries finais do Ensino Fundamental.

O jogo fez parte de uma unidade didática, a qual foi discutida em sala de aula, junto com alunos do curso de Ciências Naturais. A resposta destes alunos ao jogo, à sua aplicabilidade em sala de aula, e mesmo no que diz à sua atitude em relação à astronomia foi pesquisada e usada como principal fonte de dados para nossa análise.

Um dos propósitos essenciais deste trabalho foi avaliar a reflexão participativa de alunos acerca do tema Astronomia, assim como visualizar se há uma discussão crítica da aplicação da ciência em sociedade, por meio de atitudes demonstradas. A partir desta avaliação, foi possível identificar os conteúdos atitudinais, procedimentais e 
conceituais que foram utilizados, pelos licenciandos, enquanto jogaram o Perfil Astronômico, por meio de categorias.

No Capítulo 1, "Estado da Arte - Breve revisão na área de astronomia nos últimos doze anos", apresentamos um panorama das pesquisas em ensino de astronomia no período de 2003 a 2014.

No Capítulo 2, "O uso de recursos didáticos por professores de Astronomia no Brasil: o que pensam os professores relacionados ao OBA", será mostrada uma pesquisa realizada com cento e sessenta (160) professores do Brasil a respeito de alguns aspectos do ensino de Astronomia, como a formação dos professores desta área e sua prática em sala de aula, assim como a relevância que eles afirmam a respeito de Astronomia.

No Capítulo 3, "Brincando com astronomia", será discutido o tema a respeito de atividades pedagógicas, jogo, mas principalmente o Papel do Jogo Perfil Astronômico. Será discutido um pouco mais acerca dos materiais existentes na área do ensino de astronomia, como livros e recursos didáticos. Neste mesmo Capítulo, estarão presentes toda a história do Jogo, criado pela autora, e sua descrição e possibilidades.

No Capítulo 4, dissertaremos sobre a metodologia da pesquisa, apresentando as categorias que elaboramos, a partir da fundamentação teórica, das quais alocamos os dados observados. A elaboração das categorias foi um instrumento para a interpretação dos dados coletados. Apresentamos, também, as condições em que a pesquisa foi realizada, tais como o local e o grupo onde o trabalho foi desenvolvido.

Os resultados serão expostos e discutidos no capítulo 5, apresentando nossas interpretações sobre eles à luz da fundamentação teórica.

O último Capítulo, “Conclusões e perspectivas”, discutirá acerca das contribuições deste trabalho para o ensino de astronomia e do Jogo Perfil Astronômico como recurso didático. 
A pesquisa é a essência da

Ciência;

A Ciência é o pilar da Sociedade em que vivemos;

Logo, a pesquisa é

fundamental para a vida

humana.

(Gerson Mól) 


\section{ESTADO DA ARTE - BREVE REVISÃO NA ÁREA DE ASTRONOMIA NOS ÚLTIMOS DOZE ANOS}

O estudo realizado pela autora sobre o ensino de Astronomia na área de Ensino de Ciências nos traz um panorama sobre as pesquisas do tema nos últimos doze anos. Foi elaborado a partir de uma revisão das pesquisas e trabalhos já realizados recentemente, situando os trabalhos do Brasil.

Nesse trabalho, foi realizada uma revisão de literatura que mostra o Estado da arte sobre o ensino de astronomia, no período de 2003 a meados de 2014, em periódicos que publicam pesquisas na área de ensino de ciências, e foram encontrados sessenta e um artigos relacionados ao ensino formal.

Como o foco desse trabalho foi o ensino formal, entende-se por educação formal, segundo Langhi e Nardi (2009), como sendo aquela que

ocorre em ambiente escolar ou outros estabelecimentos de ensino, com estrutura própria e planejamento, cujo conhecimento é sistematizado a fim de ser didaticamente trabalhado. Por isso, as práticas educativas da educação formal possuem elevados graus de intencionalidade e institucionalização, sendo sua obrigatoriedade garantida em lei. (Langhi e Nardi, 2009, p. 02)

Também é importante quando Langhi \& Nardi (2009) abordam, no que concerne à literatura nacional, que se identifica certa carência de revistas científicas especializadas sobre educação em astronomia. A Revista Eletrônica Latino-Americana de Educação em Astronomia (RELEA) é a única publicação específica no país que contempla artigos sobre a pesquisa em ensino de astronomia. Há também pesquisas desta natureza publicadas nos Anais das Reuniões Anuais da Sociedade Astronômica Brasileira, que neste ano, de 2014, completa quarenta anos.

Todavia é importante salientar que, ao buscar trabalhos da área, encontramos uma revisão da literatura realizada por Bretones e Megid Neto (2005), sobre as pesquisas em ensino de astronomia. De forma geral, dentro do contexto de pesquisas em astronomia, eles encontraram cerca de mil dissertações de mestrado e teses de doutorado e livre-docência produzidos entre os anos de 1970 e 2002, o que representa 
uma significativa produção sobre astronomia em suas diversas áreas, ou seja, na área específica de astronomia, no ensino formal, não formal, informal e divulgação científica (LANGHI \& NARDI, 2009). Os autores separaram os estudos, que foram levantados por categorias, e encontraram apenas 16 trabalhos sobre o ensino de astronomia.

A pesquisa foi sintetizada destacando os seguintes aspectos que consideraram relevante em seu trabalho: instituição de realização da pesquisa, ano de defesa, nível escolar abrangido no estudo, foco temático do estudo e gênero da pesquisa do trabalho acadêmico (BRETONES \& NETO, 2005).

A partir do estudo de Bretones e Megid Neto (2005), procuramos investigar como estão as publicações em periódicos sobre o ensino de astronomia no Brasil nos últimos doze anos, destacando o foco temático das pesquisas, que será explicado neste capítulo.

Em um primeiro momento, foram selecionados os periódicos que tratam do ensino de ciências, enfatizando os estudos voltados para o tema. Para isso, demos preferência em fazer a busca nos bancos de dados relacionados à área de pesquisa em ensino de astronomia. As pesquisas foram feitas na Revista Brasileira de Ensino de Física, Caderno Brasileiro de Ensino de Física (antigo caderno catarinense), Revista Latino Americana de Educação em Astronomia, revista A Física na Escola e a revista ENSAIO. Entretanto, foram encontrados artigos na busca de trabalhos relacionados ao tema da pesquisa, nos periódicos Revista Brasileira de Estudos Pedagógicos, Revista Ciência e Educação, Revista Educação e Pesquisa, Revista Educação e Sociedade e Revista Pesquisa Qualitativa.

Foram escolhidas as palavras-chave ensino, astronomia, ensino formal, ensino de ciências, ensino de física, astrofísica, astronomia no ensino, educação, escola, ensino de astronomia. Cabe ressaltar que essas palavras-chave foram utilizadas como forma de busca no site Google, em primeiro momento, e depois foram observadas, pesquisadas nas Revistas que foram mencionadas neste trabalho. Esses termos estão ligados diretamente ao ensino de astronomia, e destacam o ensino formal, por se tratar do interesse de investigação. Foram excluídos os estudos relacionados ao ensino não formal e a divulgação científica, por serem outros campos de pesquisa e de literatura diversa.

A partir das palavras-chave utilizadas, foram encontrados sessenta e um artigos desenvolvidos entre os anos de 2003 e 2014. Por meio das leituras dos trabalhos, especialmente o resumo e as palavras-chave, os artigos foram separados em focos 
temáticos, de acordo com os critérios escolhidos na pesquisa realizada por Bretones \& Megid Neto (2005). Definimos os critérios como ano de publicação, foco da pesquisa, quantidade de publicações em cada ano a respeito de cada tema, e construímos a tabela 1, apresentando a distribuição dos trabalhos pesquisados pelo conjunto de focos temáticos escolhidos.

Tabela 1 - Focos da pesquisa em ensino de Astronomia.

\begin{tabular}{lccccc}
\hline & $\begin{array}{c}\text { Formação de } \\
\text { professores }\end{array}$ & Currículos & $\begin{array}{c}\text { Recursos } \\
\text { didáticos }\end{array}$ & $\begin{array}{c}\text { Conteúdo e } \\
\text { método }\end{array}$ & Total/ano \\
\hline 2003 & - & 1 & - & - & 1 \\
\hline 2004 & 1 & 1 & - & - & 2 \\
\hline 2005 & 3 & 1 & - & - & 4 \\
\hline 2006 & 1 & - & - & 1 & 2 \\
\hline 2007 & 3 & 1 & 2 & - & 6 \\
\hline 2008 & - & 1 & 3 & 5 & 9 \\
\hline 2009 & 5 & - & 2 & 2 & 14 \\
\hline 2010 & 2 & 1 & 6 & 5 & 1 \\
\hline 2011 & - & 2 & 4 & - & 2 \\
\hline 2012 & 1 & - & - & - & - \\
\hline 2013 & 1 & 1 & - & - & 61 \\
\hline 2014 & - & - & 17 & & 5 \\
\hline Total & 17 & 9 & & - & 18 \\
\hline
\end{tabular}

Por meio da tabela 1, pode-se observar um número grande de estudos: quatorze trabalhos relacionados a astronomia, em relação ao ano seguinte do Ano Internacional de Astronomia, que ocorreu em 2009, e onze trabalhos no ano 2011. Um ano antes deste evento constatou-se nove trabalhos. Pode-se concluir que se promove mais notoriedade à área, quando algum evento relacionado à astronomia acontece.

Não foram encontrados muitos trabalhos na área de ensino formal de astronomia, se comparado a outro campo da astronomia, como a astronomia estelar.

Viu-se, em artigos da Revista Brasileira de Estudos Pedagógicos, que os professores têm dificuldade em usar recursos didáticos diversificados; pois, além de não os encontrarem com facilidade, foi lido que não tinham estímulos para usá-los, e não 
sabiam usar. Para frisar o que foi encontrado em artigos destas revistas, Borges (2000) afirma que

[...] muito frequentemente, conforme temos observado em nossos trabalhos de formação continuada, os professores desconhecem não apenas as melhores formas de utilizar materiais, como, também, a existência de muitos deles. [...] não há, entre os professores, uma "memória" do material didático produzido nos últimos anos. Pouco se conhece além daquilo que é mais recente e dos livros didáticos mais comuns. (Borges, 2000, p.222)

De acordo com leituras nas revistas Ciência e Educação, Educação e Pesquisa e Revista Brasileira de Estudos Pedagógicos, vimos que professores apresentam certa dificuldade para trabalhar em grupo, para organização e melhoria da escola, e, às vezes, demonstram falta de solidez para ensinar conteúdos. Damiani (2008) afirma que os professores juntam os trabalhos ao invés de trabalharem juntos, e isso se aplica, de maneira intensa, às instituições escolares, nas quais tanto as atividades pedagógicas quanto as administrativas são, usualmente, realizadas de maneira individual.

Quando um professor não sabe um conteúdo que deve ser ensinado, pode ficar restrito ao ensino de regras e à realização de um exercício mesmo sem compreender e sem ensinar seu propósito. O livro didático é fundamental para esses professores. $\mathrm{O}$ contexto e a história em relação a algum conteúdo, assim como sua aplicação e abordagem, podem não aparecer como estrutura da explicação do professor ao aluno. Percebe-se que, quando um professor tem dificuldades e carência de domínio de conteúdos, fica mais difícil aplicar um conhecimento. "A realidade da maioria das escolas mostra que o livro didático tem sido praticamente o único instrumento de apoio ao professor" (FRISON, M. et al., 2009, p.3). Ademais dessa afirmação, pesquisa em ensino de ciências indica que os livros didáticos constituem um dos principais suportes para a atividade acadêmica dos professores. Segundo Frison (2009), o uso de recursos didáticos diferenciados fica como última escolha ou mesmo não são colocados em sala de aula. É de grande valia para a aprendizagem que o professor queira aprender e ensinar usando diferentes recursos didáticos. Neste cenário, é devido sinalizar a importância de um professor ter domínio de conteúdos e técnicas para ensinar com mérito. Bretones (2006) afirma que 
a orientação de formação continuada não estimula o desenvolvimento da autonomia do professor e nem mesmo a aquisição de conteúdo. Para seguir receitas o professor, talvez, não precise saber o conteúdo. As técnicas didáticas e as abordagens pedagógicas também são necessárias para a formação dos professores. Isto vai desde a construção e uso de modelos, recursos audiovisuais até a discussão da pertinência ou não de certo conteúdo num programa escolar, nos parâmetros curriculares, nos livros didáticos. (Bretones, 2006, p.10)

Concluindo, professores carecem de formação na área de astronomia, mesmo em cursos de Física, Ciências ou Geografia. Por mais que a astronomia esteja presente no dia a dia, em revistas, livros, eles se sentem inseguros para ensinar esta área ou partes específicas dela. Sabe-se que o ensino de astronomia não é comum, devido à má formação dos professores que a deveriam ensinar. Esta carente formação dos professores, foi mostrada por meio de uma pesquisa realizada por Bretones (1999) e por outra pesquisa feita pela autora deste trabalho, Martinez (2011), que será apresentada no próximo capítulo. Neste contexto, compreender os aspectos e o desenvolvimento de professores em seu campo de trabalho, perceber seus objetivos, seus valores e suas características individuais, as situações de seu cotidiano e a atmosfera escolar a que eles pertencem, são possíveis caminhos para a produção de algum material que se adeque ao uso de professores. Estes aspectos podem servir de guia para que seja feito um material acessível e que seja recebido pelos professores. Os professores poderão criar autonomia e posição própria para sua atuação didática ao usar materiais que foram criados considerando seu âmbito de trabalho. 
Muitas crianças nascem cientistas. Muito curiosas, questionam tudo e se encontram dispostas a explorar o mundo. Infelizmente este desejo se esvai com o tempo tanto quanto o ato de brincar ou jogar. Talvez o educador tenha que perceber isso e trazê-los de volta.

(Ivan Ferreira) 


\section{O USO DE RECURSOS DIDÁTICOS POR PROFESSORES DO ENSINO DE ASTRONOMIA NO BRASIL: O QUE PENSAM OS PROFESSORES RELACIONADOS AO OBA}

Segundo o levantamento sistemático de Bretones (1999) em projeto de mestrado, os cursos superiores no Brasil que oferecem disciplinas específicas de Astronomia são poucos, abrangendo 31,4\% dos cursos de Física (22 em números absolutos); 7,4\% dos cursos de Geografia (13 em números absolutos) e 4,7\% dos cursos de Ciências (4 em números absolutos). Além disso, apenas parte deles oferece disciplinas de Astronomia em seus cursos de licenciatura. Entre os vinte e dois (22) cursos de Física, por exemplo, apenas sete estabelecem obrigatoriedade dessas disciplinas na licenciatura e um como disciplina optativa para esta modalidade.

Uma pesquisa realizada pela autora deste trabalho, (MARTINEZ, 2011), feita com 160 professores do Brasil, que ensinam ciências, formados em diversas áreas como ciências, biologia, geografia e pedagogia e que participam da Olimpíada Brasileira de Astronomia (OBA), teve o intuito de diagnosticar a necessidade dos professores utilizarem recursos didáticos nas escolas e se os usam atualmente. Foi observado o uso da diversidade de recursos didáticos por professores que participam da OBA, e também que consideram importante que os alunos aprendam sobre Astronomia. Essa pesquisa foi realizada a partir do site da OBA, em que o coordenador do programa nos ajudou postando um questionário para que os professores participantes respondessem. Cabe lembrar que os educadores participantes escolheram de forma espontânea se responderiam ao questionário; assim, eram docentes que estavam realmente interessados pela pesquisa e ensino de Astronomia.

É importante enfatizar que essa pesquisa possui uma amostragem estatística restrita do universo dos professores do ensino médio e fundamental, visto que foram constatados apenas professores que de alguma forma participam da Olimpíada Brasileira de Astronomia (OBA). Por isso, é uma pesquisa por amostragem de um grupo de professores com um perfil específico de interesse por astronomia. Foram lidas e interpretadas respostas de professores de todo o Brasil, exceto dos estados do Sergipe e do Amapá porque professores destes estados não responderam ao questionário. $\mathrm{O}$ 
importante dessa pesquisa foi perceber que há a necessidade do uso de recursos didáticos, do uso de jogos pelos professores do Brasil.

A pesquisa foi realizada por meio de um questionário elaborado que contém doze questões, porém, para o interesse deste trabalho, apresentaremos apenas as questões com foco sobre ensino de Astronomia e o uso de material didático. Para maiores esclarecimentos, nele estão relacionadas questões que visam analisar de que forma os professores lecionam Astronomia e se eles consideram que têm tempo disponível no ano letivo para atividades lúdicas. O que é chamado de recurso/material didático podia ser interpretado pelos professores que responderam à pesquisa como auxílios e complementos para suas aulas. Analisando as respostas, eles entenderam que recursos/materiais didáticos poderiam ser jogos, materiais de construção em sala de aula e outros aparatos que não fossem livros didáticos e nem mesmo quadro e giz. As porcentagens em relação às respostas serão mostradas neste capítulo.

A primeira pergunta do questionário ( $A$ astronomia é importante?) é uma questão do tipo aberta, subjetiva, à qual o professor respondia, se considera importante que os estudantes do ensino fundamental e médio aprendam a respeito do tema Astronomia. As respostas indicaram que os professores acreditam que o ensino de astronomia é importante. Oitenta e um professores, ao respondê-la, disseram que os alunos precisam aprender Astronomia porque é um campo da Ciência em que há interligação de conteúdos e que, ao aprenderem sobre o tema, os alunos entendem mais sobre si mesmos (Figura 1).

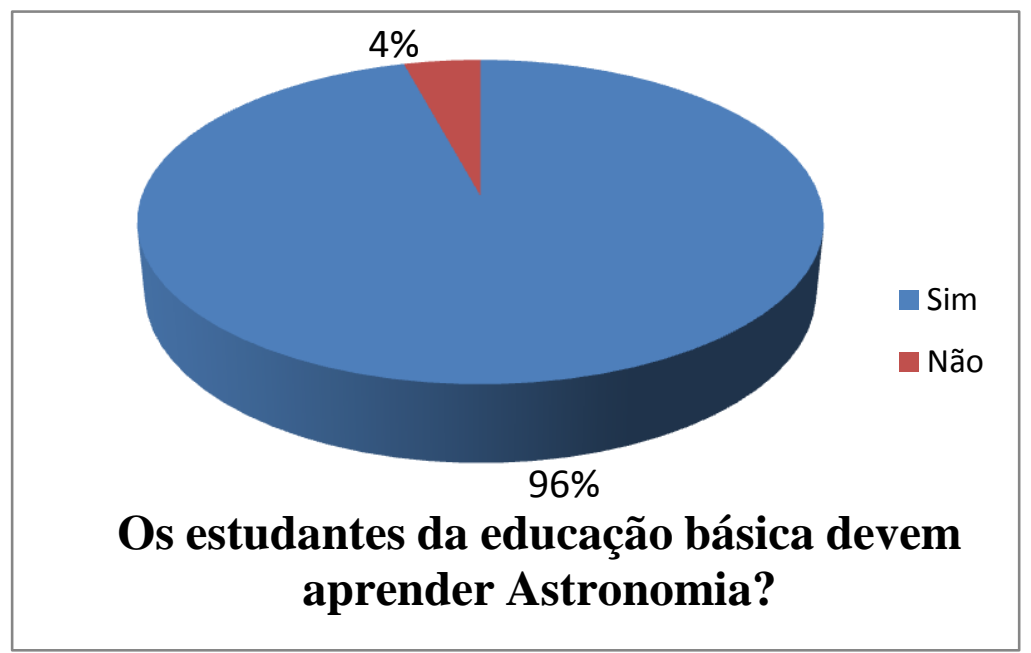

Figura 1 - Os estudantes da educação básica devem aprender Astronomia? 
A Figura 2 apresenta as porcentagens das respostas da pergunta que questiona se os professores acham que os alunos devem estudar Astronomia mais de uma vez na Educação Básica. Vemos que a maioria dos professores considera importante que o aluno veja o tema Astronomia mais de uma vez, em sua formação (Figura 2).

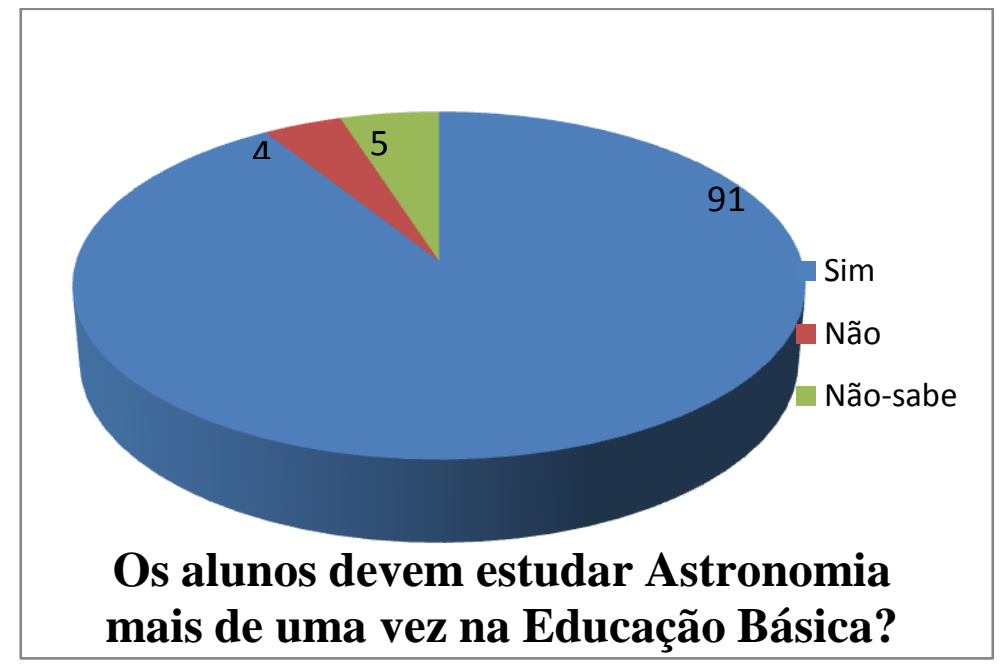

Figura 2 - Distribuição de respostas sobre a questão de se estudar Astronomia.

A outra questão analisada (Estudou astronomia em sua formação?) procura saber se os professores estudaram astronomia durante sua formação profissional, mesmo na graduação, em cursos complementares ou em alguma pós-graduação. A Figura 3 mostra tanto a distribuição nacional, em que $77 \%$ dos professores participantes respondeu que não estudou Astronomia em sua formação, quanto à distribuição por região brasileira. Viu-se que os professores que responderam de maneira afirmativa a essa pergunta foram, em maioria, pertencentes à região Sul e também à região CentroOeste do Brasil.
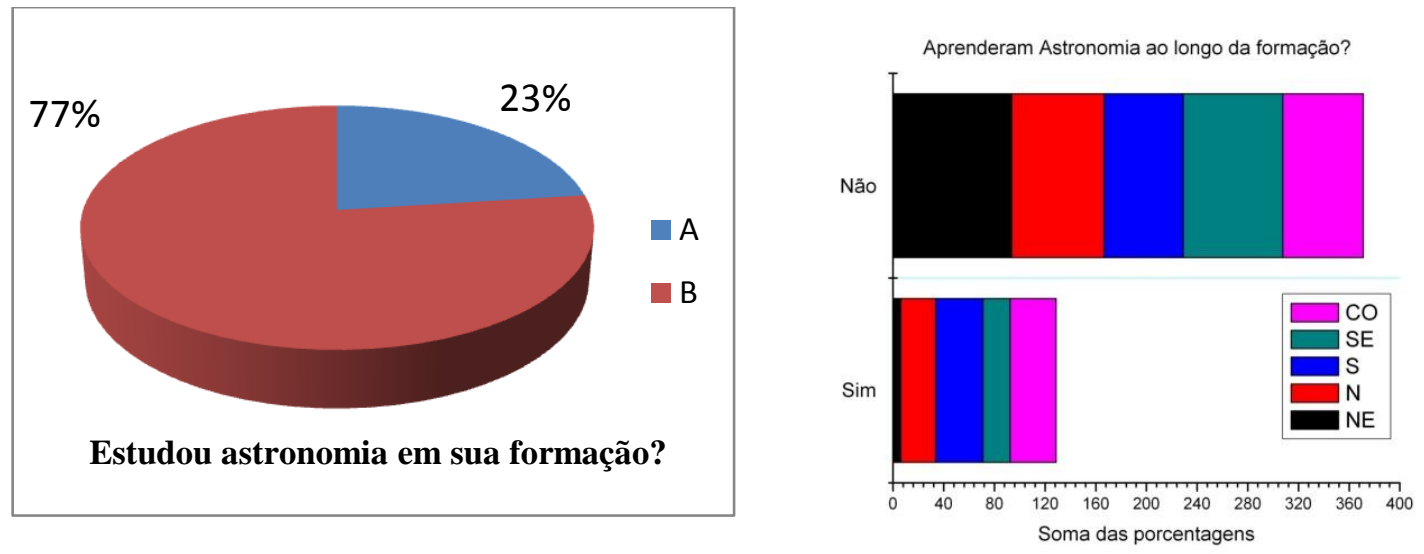

Figura 3 - Distribuição relativa de professores que participaram de cursos de Astronomia ao longo da sua formação. 
Na questão em que foi indagado se os professores ensinam ou não o conteúdo astronomia em sala de aula, 89\% afirmou que ensina. A Figura 4 apresenta as porcentagens das respostas dos professores sobre se eles ensinam ou não astronomia em sala de aula. Quando perguntamos isto, queríamos também saber se os professores respondentes estavam envolvidos no ensino de astronomia ou não.

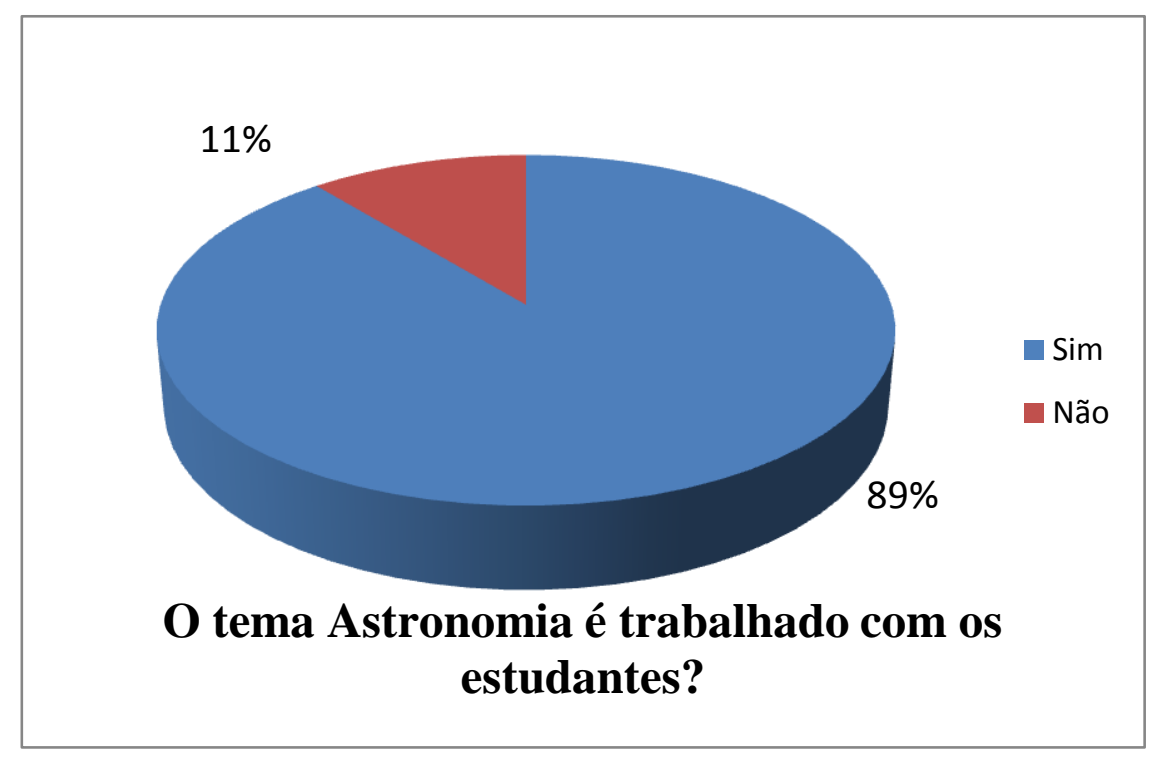

Figura 4- Professores que ensinam Astronomia em sala de aula.

A Figura 5 apresenta uma distribuição do número de professores do Ensino Básico, que responderam ao questionário, e que ensinam astronomia pelas regiões brasileiras. Constata-se que a região Sul é onde mais professores ensinam Astronomia, seguido pela região Sudeste e pela região Centro-Oeste. Com a Figura 5 é possível entender, de acordo com as porcentagens, que a maioria dos professores da OBA que participou dessa pesquisa e ensina Astronomia no Ensino Básico está na região Sul e Centro-Oeste, mas isso pode não ser a realidade entre os professores que não participam da OBA. 


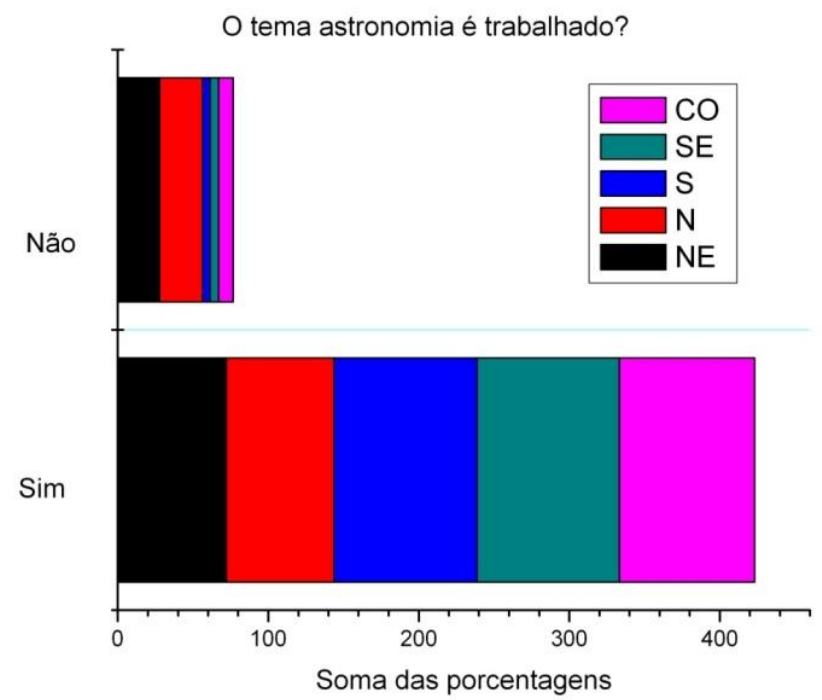

Figura 5 - Porcentagem de professores, por região, que ensinam Astronomia.

A outra pergunta ( $O$ que é utilizado em sala para se ensinar astronomia?) foi referente ao material que o professor utiliza para complementar sua aula e havia onze opções para escolha, mais um espaço para escrever na opção outros. Pode-se observar, a partir das porcentagens da Figura 6, que o material didático mais escolhido foi a internet, sendo mais usada que o livro didático que aparece como segunda opção mais escolhida. Logo em seguida, aparecem os documentários e os filmes.

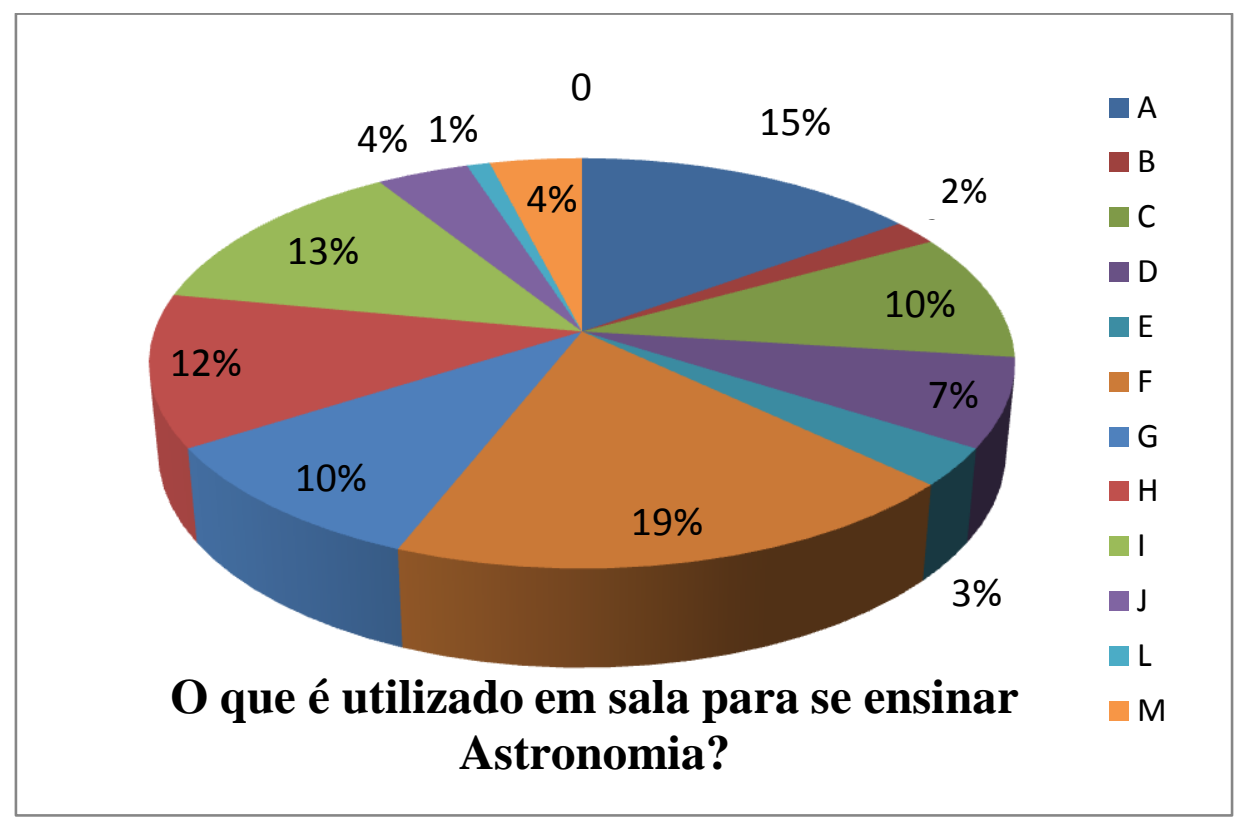

Figura 6 - Com o que os professores pesquisados complementam a aula ao ensinar Astronomia. 
As opções relacionadas à Figura 6 foram as seguintes:

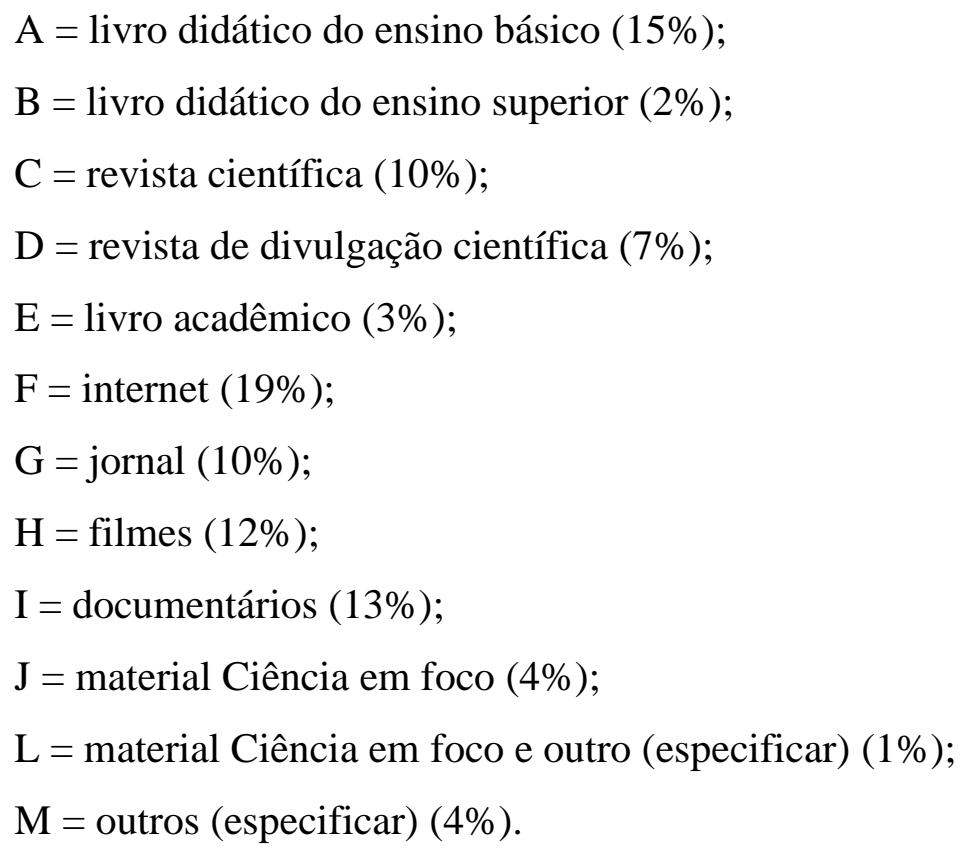

Não foi surpresa o resultado da resposta anterior referente ao uso da internet, pois os professores que participam da OBA de alguma forma já tem acesso à internet e buscam material para ensinar aos seus alunos. Possivelmente, se fosse um conjunto de professores em outro contexto, o resultado apontaria o livro didático.

$\mathrm{Na}$ outra pergunta analisada (Já visitou sites procurando atividades para desenvolver junto aos alunos?), houve o questionamento se os professores buscavam auxílio de sites para acessar novas atividades, com o intuito de desenvolvê-las com os alunos. A resposta foi condizente com a questão anterior. A partir da Figura 7, pode-se observar que $59 \%$ dos professores já procuraram atividades complementares para o ensino de astronomia, em sites. 


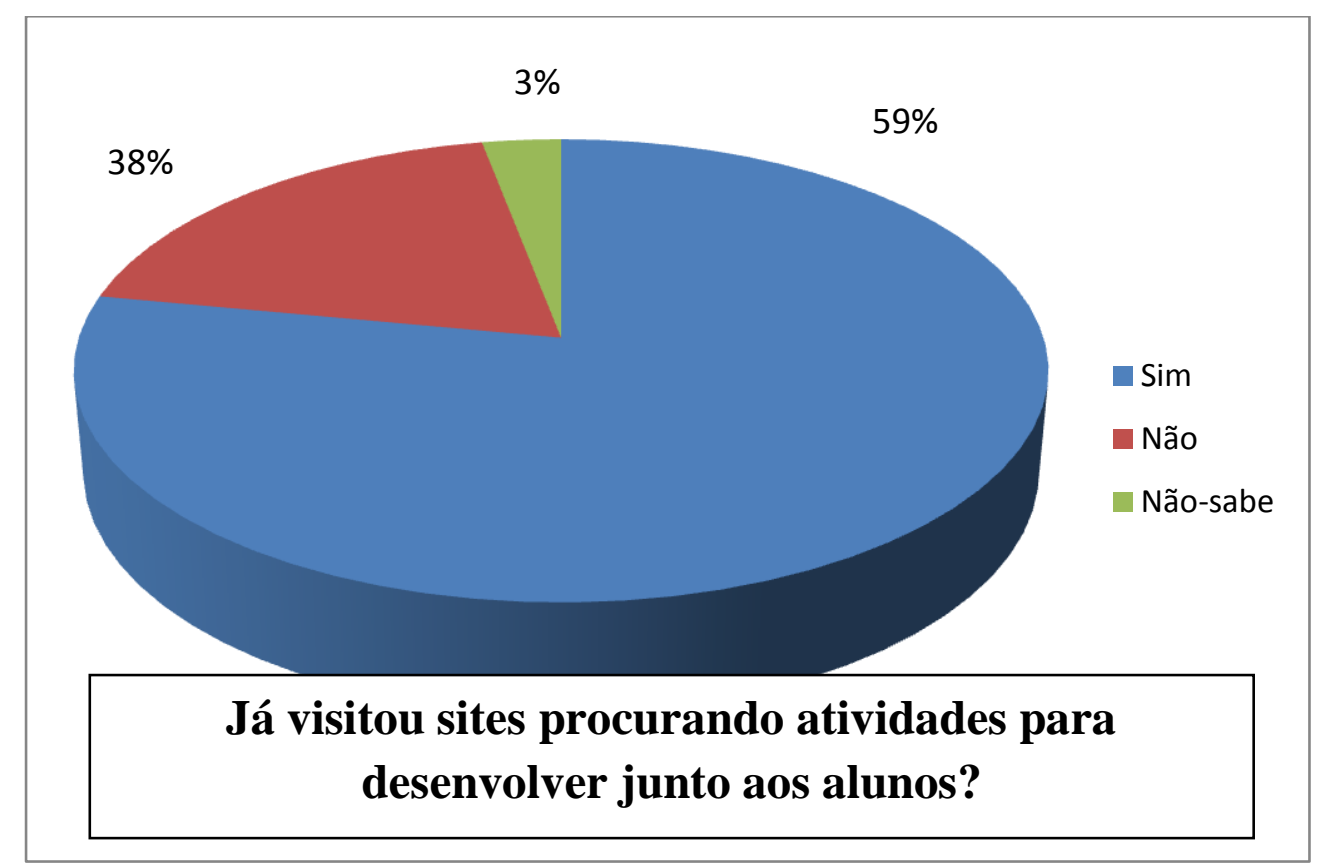

Figura 7 - Porcentagem das respostas da questão: já visitou sites procurando atividades para desenvolver junto aos alunos?

$\mathrm{Na}$ próxima pergunta (Já experimentou o lúdico e jogos em sala de aula?) procurou-se analisar se os professores utilizam o lúdico em sala de aula, e foram vistas respostas relacionadas aos jogos também. Ressaltamos que lúdico pode ser trabalhado sem o uso de jogos, mas pode-se aplicar um jogo utilizando do processo do lúdico. Os jogos têm um papel importante no que se refere ao desenvolver do caráter investigativo e lúdico de um estudante. Pesquisas na área de educação indicam que o uso do lúdico propicia a aprendizagem. Pode-se observar que professores, em geral, têm esta visão em comum de que ensinar de forma lúdica gera resposta eminente. Os professores pesquisados $(56 \%)$ afirmaram que já utilizaram a abordagem lúdica em sala de aula (Figura 8). É o lúdico como sendo diferente de quadro e giz e em que aparecem materiais didáticos e dinâmicas. 


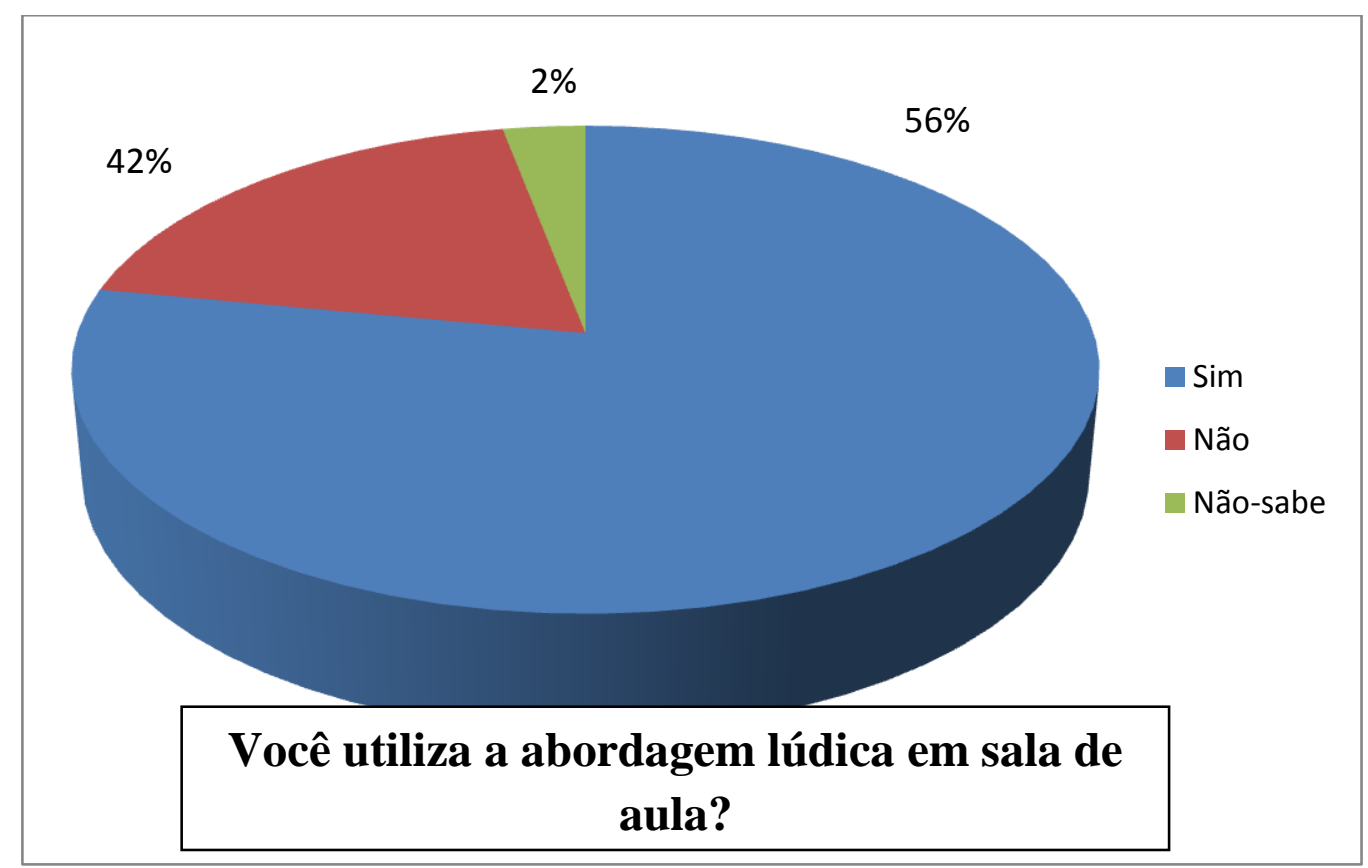

Figura 8 - Porcentagem das respostas para a questão: já experimentou o lúdico e jogos em sala de aula?

Então, a maioria dos professores, 56\%, respondeu que é importante ensinar de maneira lúdica. Disseram que veem uma resposta rápida e clara do aluno, quando se utilizam destes recursos para ensinar. Alguns, que optaram pelo não, justificaram dizendo que não há espaço na escola e que não têm ideias do que utilizar em sala, mas se deixassem uma atividade à disposição, usariam.

No que se refere à outra pergunta do questionário (Há tempo e espaço ao longo do ano letivo para aplicar atividades lúdicas e jogos?) que explora se há tempo e espaço para que atividades lúdicas e jogos sejam desenvolvidos, $78 \%$ dos professores responderam que sim. Isso facilita o desenvolver do lúdico e, em particular, possibilita espaço para que jogos sejam trabalhados dentro da escola (Figura 9). Cabe frisar que uma abordagem lúdica não necessariamente ocorre fora de sala de aula. 


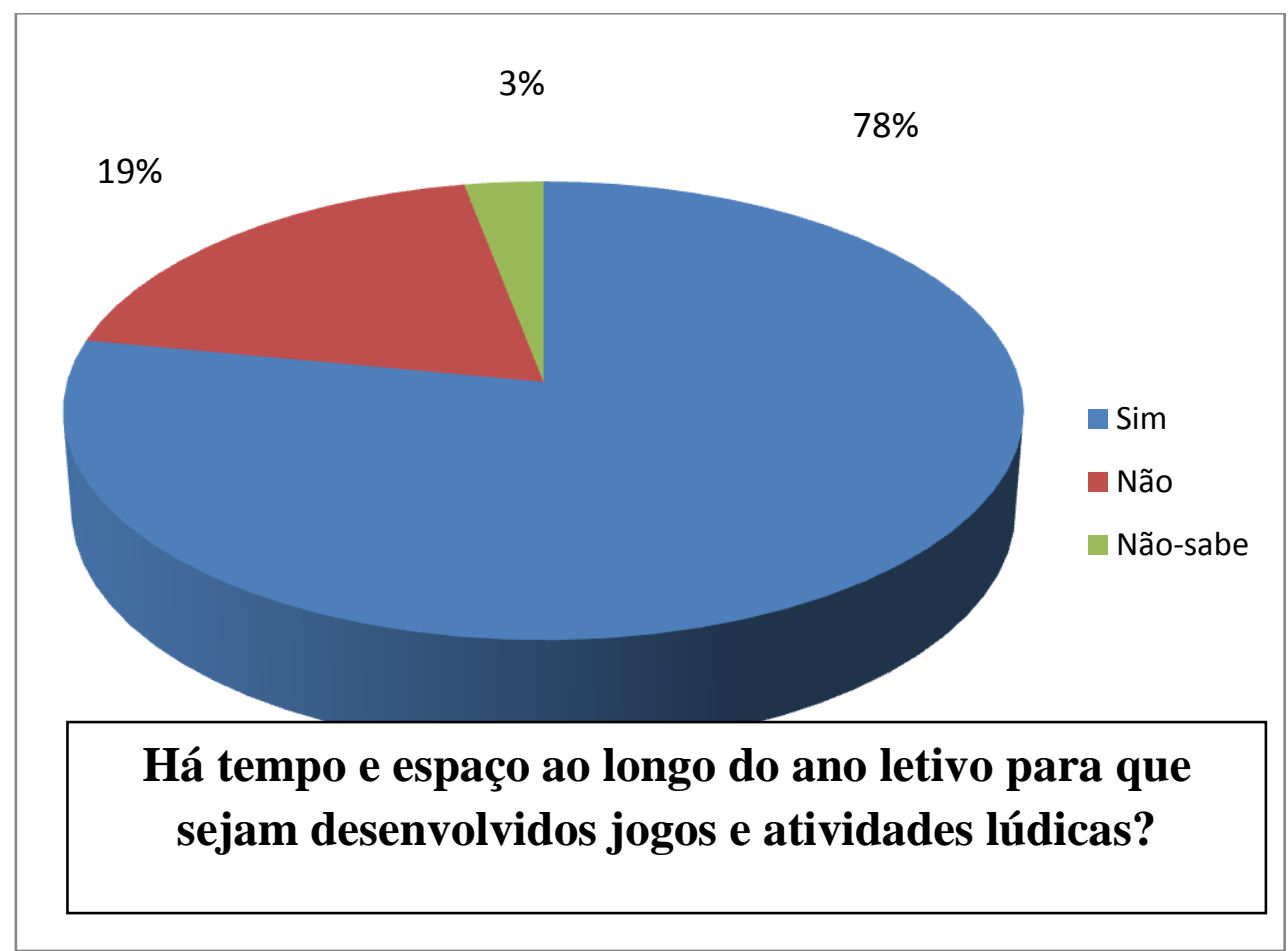

Figura 9 - Há tempo e espaço ao longo do ano letivo para que sejam desenvolvidos jogos e atividades lúdicas?

Atividades lúdicas, em que pode haver interação entre os participantes do ensino, baseadas na contextualização do que o aluno vive e os conhecimentos astronômicos, permitem um ambiente em que haja conversa, diálogo entre professor e aluno, em que questionamentos são gerados e tende a ocorrer aprendizagem com significados. Mas se faz necessário o interesse pelo conhecimento e a participação dos professores e, também, dos alunos.

Perrenoud (1999) escreve sobre a crise no ensino de Ciências, abordando um desinteresse pelos conteúdos e uma crítica à metodologia aplicada em sala de aula. Quando são trabalhados jogos e atividades lúdicas, é proposta uma abordagem diferenciada que pode modificar este panorama e propiciar uma abordagem interdisciplinar da Astronomia. Cabe ressaltar que trabalhar de forma lúdica não pressupõe interdisciplinaridade, mas é possível alcançá-la caso o professor ou o orientador se proponha a fazer esse trabalho.

De acordo com as respostas subjetivas, escritas pelos professores que participaram da pesquisa, notamos que, no público alvo pesquisado, há uma tendência para o ensino por meio de material lúdico, e que os professores tiveram uma boa devolutiva do aluno no desenvolvimento do ensino/aprendizagem quando o utilizavam. 
Cabe lembrar que esses professores participam da Olimpíada Brasileira de Astronomia e, de certo modo, são direcionados a usar recursos didáticos, buscar materiais em sites, entre outros.

Entendemos, depois de analisar as respostas, que quando não se tem uma boa formação em determinada área, deve-se buscar informações em fontes alternativas. Esta conclusão gera muitas reflexões e uma delas é que muitas vezes este pensamento tem como efeito a presença e a introdução de conceitos e ideias errôneas a respeito do tema, e que podem ser transmitidas às gerações vindouras.

Esta pesquisa, que foi relatada, descrita neste Capítulo, gera motivação para se estudar o ensino de astronomia e produzir conhecimentos sobre o uso de jogos para ajudar professores em sala de aula. Para eles, envolvidos na vivência diária, pode ser difícil produzir novos materiais, mas têm carência deles. A presente dissertação buscou investigar até que ponto o Jogo Perfil Astronômico pode auxiliar ao desenvolvimento do pensamento, em seus aspectos atitudinais, procedimentais, além dos conceituais, em estudantes que o jogaram, melhorando um recurso didático que será disponibilizado para professores. 
Os jogos dos nossos neurônios nos dizem, a cada instante, o que achávamos que jamais poderíamos pensar ou aprender.

(Izabel Guedes) 


\section{BRINCANDO COM ASTRONOMIA}

Todo o conhecimento é resposta a uma pergunta. Gaston Bachelard

O diálogo a ser conduzido em atividades pedagógicas não é falatório vazio; mas, sim, é a contextualização e o questionamento do conhecimento (LEÃO, 2012, p.45). Uma didática embasada na indução de curiosidades, perguntas, e busca de respostas é vista como uma alternativa com grandes possibilidades ao desenvolvimento cognitivo de um aprendiz.

Um estudante pode se tornar ativo, pensante e inquieto, que faz perguntas e resolve problemas, caracterizando o espírito científico, de investigação e geração de conhecimentos. "Se não há pergunta, não pode haver conhecimento científico. Nada é evidente. Nada é gratuito. Tudo é construído” (BACHELARD, 1996, p.18).

Na educação existe comunicação, que é construída entre professor e estudante, em que o aluno indaga, responde, mas o professor pode ser um agente para direcionar o que o aluno encontrou como informação e resposta. A comunicação, quando guiada pelo conhecer, pode transformar um ser humano em sujeito participante, questionador, curioso.

Esta ponte entre pergunta e resposta direcionada pode ser bem construída neste cenário de interação formal, que está sendo tratado neste trabalho. 


\subsection{Papel do Jogo}

Se você falar com um homem numa linguagem que ele compreende, isso entra na cabeça dele. Se você falar com ele em sua própria linguagem, você atinge seu coração.

Nelson Mandela

Um jogo tem um grande potencial de divertir, entreter ou recrear. Desde a Grécia antiga, têm-se relatos que fazem parte da sociedade. Pode ser uma brincadeira se apenas tiver o objetivo de diversão e não de aprendizado. Mas um jogo pode estimular o aprendizado concomitante à diversão. Segundo Bittencourt (2013), o jogo é uma atividade que se configura como fundamental no processo de formação existencial do ser humano e representa a instauração simbólica de uma reapropriação criadora do tempo em uma atividade afirmadora da vida e do prazer próprio da ludicidade.

Quando se joga, de maneira geral, tem-se a liberdade de julgamento e de preocupação moral, mas podem ser criados valores éticos. Mesmo em meio às regras a serem seguidas, é possível jogar com tamanha liberdade, perguntar, ser curioso, falar o que se pensa, que aprender é uma consequência natural.

Na Grécia antiga, os esportes e os jogos tinham grande relação com a educação, e buscava-se integração entre o corpo e o espírito. Além das práticas esportivas, os gregos mantinham outros tipos de jogos em tempo de descanso com o propósito de educar. Até hoje eles jogam com o intuito de aprender e também divertir. A prova definitiva de que os jogos tiveram grande peso na educação do povo grego foi a criação das Olimpíadas (BITTENCOURT, 2013). Pessoas aprendem por meio de jogos, e esta consequência pode ser melhor aproveitada pelos povos. Ainda dialogando com a interpretação de Bittencourt (2013), o ato de se estabelecer a presença do jogo na vida cotidiana não pode de modo algum ser interpretado como uma saída da experiência laboral em prol do entretenimento e da distração, mas como uma necessidade sagrada da condição humana, imediatamente atrelada ao ritmo da natureza.

Nesta direção, deve-se pensar em específico no papel do lúdico na educação. É notável que a discussão do lúdico e do jogo não é recente, e autores como Piaget (18961980) e Vygotsky (1896-1934), assim como outros que serão citados, discorrem acerca destes temas. 
Conforme a definição de Miranda (2001), a atividade lúdica é essencialmente um grande laboratório em que ocorrem experiências inteligentes e reflexivas. Ainda diz que a experiência produz o conhecimento. Soares (2008) afirma que a atividade lúdica pode ser definida como uma ação divertida, relacionada aos jogos, seja qual for o contexto linguístico, com ou sem a presença de regras, sem considerar o objeto envolto nesta ação. $\mathrm{O}$ autor afirma que certas ações podem gerar um mínimo de divertimento. Em outro momento, este mesmo autor diz que

a atitude lúdica é aquela demonstrada pelo jogador ou por um grupo destes. Quando uma atividade lúdica é composta por pessoas, participantes, jogadores e estes propõem a diversão, além de utilizar essa mesma diversão como um dos aspectos de sua vivência, dizemos ser esta uma atitude lúdica, que é o próprio ludismo. A ludicidade é a qualidade de uma atividade lúdica, é o quanto ela pode ser divertida e prazerosa e o ludismo é a qualidade do jogador, o quanto ele pode ser comprometido com o divertimento. Um jogo educativo pode ter ludicidade e seus participantes podem ter ludismo. Um jogador sem ludismo não é jogador. (SOARES, 2008, p.65)

Nesse contexto, na visão de Retondar (2007), o lúdico tende a se manifestar arrastando os indivíduos para a emoção pura. Vygotsky (1989) relata que o lúdico liberta a criança das amarras da realidade. Piaget (1971) aborda que as atividades lúdicas sensibilizam, socializam e conscientizam. Importante perceber que pode existir jogo lúdico ou não, assim como ações como cantar e dançar.

Outra interpretação acerca do jogo é Fromberg (1976) quem faz, e este autor sugere que no jogo pode-se representar a realidade e as atitudes; a significação, na qual se permite relacionar ou expressar experiências; a atividade, no ato de se fazer coisas; o intrinsecamente motivado, para se incorporar motivos e interesses e finalmente, o regrado, o sujeito a regras implícitas e explícitas. Depois destas ideias, é possível perceber o grande potencial que uma atividade lúdica perfaz. O jogo, trabalhado em um contexto lúdico, pode auxiliar uma pessoa a desenvolver características novas em relação ao pensar, ao agir e ao conviver com os outros seres.

No livro Homo Ludens (HUIZINGA, 2000, p.3) é defendida a arte do jogo: “Já há muitos anos que vem crescendo em mim a convicção de que é no jogo e pelo jogo que a civilização surge e se desenvolve". Uma criança pode se desenvolver, também, com um jogo que tenha o potencial de divertir e de ensinar, e é o que se vê quando aplicada uma atividade lúdica, com ferramentas, com crianças e adolescentes de todas as idades, e elas aprendem mais a respeito de diversos temas abordados. "Mesmo em 
suas formas mais simples, ao nível animal, o jogo é mais do que um fenômeno fisiológico ou um reflexo psicológico. Ultrapassa os limites da atividade puramente física ou biológica" (HUIZINGA, 2000, p.3). O jogo é de fundamental importância na vida de uma criança que está se desenvolvendo. Jogos bem estruturados e jogos bem aplicados tornam-se sinônimos e complementares, quando há o objetivo de aprendizagem com diversão e boa qualidade. Uma criança ou pré-adolescente precisam de motivação para estudar. Na maioria das vezes, em sala de aula, o aluno se perde e não mantém a atenção para com o conteúdo e/ou explicação do professor, e se dispersa. Com algo diferente (afinal, o que é novo e diferente ninguém esquece) o estudante se motiva e vê sentido do conteúdo e pode fazer relação com a própria vida.

Ao pensar na palavra jogo, logo nos vêm à cabeça diversão, criatividade e alegria, pois afinal parecem sinônimos. Ainda como uma ideia afim deveria estar o aprendizado, mas quase sempre ele não é percebido. Pode não ocorrer de maneira natural, mas o ensino-aprendizagem pode sim aparecer em um jogo, mesmo que em nuances.

Neste caminhar, Soares (2008) afirma que "se o jogo, a atividade lúdica ou o brinquedo busca dentro da sala de aula um ambiente de prazer, de livre exploração, de incerteza de resultados, deve ser considerado jogo" (SOARES, 2008, p.46). Em contrapartida, um jogo pode ser lúdico e ao mesmo tempo educativo, além de prazerozo, e o professor pode ser o mediador desta junção de propósitos. Quando o objetivo é ensinar por meio do jogo, dúvidas podem ser elencadas, no sentido de como fazê-lo. Então, um direcionamento de tomada de decisões e de como proceder frente ao jogo seria como uma resposta imediata ou uma alternativa para uma prática do ensinar que tenha o intuito lúdico, utilizando-se de material didático. Em uma discussão mais aprofundada da função do jogo, há a definição de um jogo educativo que seria de forma equilibrada metade com a função lúdica e metade com a função educativa. Kishimoto (1996) explica que na parte lúdica o jogo propicia a diversão, o prazer, e na parte educativa o jogo ensina qualquer coisa que complete o indivíduo em seu saber, em seus conhecimentos e em sua apreensão de mundo.

Pensando nas diversas definições de jogo, uma simples e aprazível é a que Miranda (2001) apresenta: "O jogo fica entendido como um dispositivo facilitador para a criança perceber os conteúdos" (p.52). É visível que o jogo, quando bem estruturado e direcionado para o aprender, desempenha a tarefa de auxiliar no processo de ensino e aprendizagem. Alguns autores escrevem sobre ensinar por meio do jogo até determinada 
idade da vida, mas não é preciso parar de jogar porque se tornou adulto. Jogar motiva a alegria, possibilita o desenvolvimento em todos os pilares da própria vida e mais, pode estimular o aprender com a ludicidade. Bittencourt (2013) afirma que o espírito do jogo fornece ao ser humano a descoberta do poder criador perante sua realidade circundante, dando-lhe novos significados continuamente.

Não obstante, desde criança se tem a característica natural do brincar, e deve-se conservá-la. Mas brincar com quais perspectivas? Brincar por brincar? Pode ser, pois a criança tem este direito. Mas dentro dela está a curiosidade para conhecer, estabelecer limites, conhecer a si mesma e ao mundo. Quando ela chega a uma etapa da vida, é viável ter uma direção e ser guiada em seus pensamentos. Um jogo pode ser visto como gerador de novas estruturas mentais, um propulsor de conhecimentos, que pode auxiliar neste sentido. Estímulos visuais e sensório-motores são essenciais para se obter um bom desenvolvimento do corpo e da mente. Atitudes e novos comportamentos podem ser gerados com o auxílio do jogo, e o professor pode aplicá-lo com o intuito de desenvolver no aluno uma nova maneira de pensar.

\footnotetext{
"Através da boa observação durante o funcionamento do jogo, o professor poderá registrar também as atitudes dos alunos, bem como: o espírito de cooperação, o relacionamento, o poder de observação, a atenção, o interesse, o poder de concentração, a comunicação, o desembaraço. [...] o professor poderá levantar dados de cada aluno e orientá-lo". (ALMEIDA, 1990, p. 52)
}

Por meio de uma orientação dos professores aos alunos, fica mais acessível perceber suas dificuldades e a melhor maneira para ajudá-los. É possível observar as novas perguntas e atitudes dos alunos, quando um jogo é aplicado. Ensinar a pensar e a ver o mundo de forma diferente é uma ação que demanda planejamento, e quando se tem algo construído com este propósito, como um jogo, o trabalho fica ao alcance de professores e também de alunos.

Trabalhar com os alunos a respeito de um tema de forma diferenciada, como por meio de um jogo, pode contribuir para o entendimento do aluno acerca de conteúdos, e é uma maneira mais prática de ensinar em sala de aula. Perguntas podem ser geradas e os jogos podem contribuir para responder a algumas delas.

Entende-se ser importante aproveitar as perguntas dos estudantes e incentivá-los a indagarem cada vez mais. Atitudes críticas e atitudes reflexivas podem começar por meio de perguntas, e quando são embasadas em aspectos históricos, em contextos 
científicos, têm um grande potencial no que concerne ao desenvolvimento do pensamento de um indivíduo.

Neste sentido, a Astronomia é efetiva para responder perguntas que surgem ao jogar em sala de aula, por exemplo. Mas para torná-la mais acessível, é de suma importância que o educador saiba articular o conteúdo e tenha recursos para que consiga uma boa devolutiva do educando.

Leite e Hosoume (2008) afirmam que

a Astronomia, quando trabalhada no ensino fundamental, é desenvolvida de forma tradicional e apenas conceitual, e as representações dos elementos constituintes são abordadas, geralmente, apenas em forma de texto ou de imagens bidimensionais. Temos consciência de que a metodologia de aula não pode mais ser a indicada tradicionalmente nos livros didáticos, pois ela já se revelou ser insuficiente. Devido à natureza abstrata do tema, ele deve, na medida do possível, ser vivenciado de forma prática e concreta. (LEITE; HOSOUME, 2008, p. 66)

Ao perceber as perguntas dos estudantes e a curiosidade evidente, mostrar-lhes uma maneira de compreender o conteúdo de forma prazerosa, é plausível. Jogos na área de Astronomia podem ser considerados meios importantes que possibilitem o aprendizado de maneira prática, concreta e também efetiva.

\subsection{Alguns jogos existentes que podem ser utilizados na área de ensino de astronomia}

No que concerne aos jogos na área de Astronomia, ainda não é comum encontrálos disponíveis para professores, porém o livro Jogos para o ensino de Astronomia (MARTINEZ \& FERREIRA, et. al. 2013), da editora Átomo, apresenta uma coletânea de jogos da área:

- Trilha da Lua, de M. L. Lima;

- Desbravando o Sistema Solar, de R. F. Pereira, P. A. Fuzinato e M. C. D. Neves;

- Da Terra, da Lua e Além, de R. F. Pereira, P. A. Fuzinato, M. C. D. Neves e M. C. Batista;

- Aprender Astronomia Jogando, de R. M. Ros;

- O Perfil Astronômico, de Isabella Guedes Martinez e Ivan S. Ferreira; 
- O Trunfo Bellatrix, de Isabella Guedes Martinez e Ivan S. Ferreira;

- Astro-imagem, de A. T. Bruno e J. Romanzini;

- AstroTwister, de D. T. Sanzovo e V. Queiroz;

- Boliche das Galáxias, de R. H. Trevisan e C. Lattari;

- Os Bingos de Astronomia, de P. S. Bretones e O. H. O. Pavan.

Os jogos do livro citado têm o objetivo de ensinar e também, como consequência, despertar o interesse do aluno. Os jogos foram criados com a meta de gerar a construção do conhecimento, promovendo a aprendizagem concomitante à ludicidade e diversão. Nestes jogos podem ser desenvolvidos níveis diferentes de experiência pessoal e social e eles têm capacidades de construir novas descobertas para quem joga. $\mathrm{O}$ professor, estando na condição de mediador da aprendizagem e do conhecimento científico, auxiliará na construção do saber e aproximará os alunos do próprio conhecimento. Em nossos estudos, acreditamos que os jogos podem ajudar o ensino de astronomia de forma mais prática e lúdica.

O livro Jogos para o Ensino de Química (SOARES, 2008), apresenta alguns recursos didáticos, e alguns são jogos. O Jogo da Lei de Lavoisier (p.83), em que o propósito é ensinar acerca da afirmação de Lavoisier "na natureza nada se perde, nada se cria, tudo se transforma" por meio de bolas de isopor e palitos de dentes, possibilita fazer uma relação com a história da astronomia e do universo, enfatizando a origem de tudo que se encontra no espaço. O jogo Dominó Químico (p.114) também pode ser usado em sala com os mesmos intuitos, por exemplo. Logo em seguida, aparece um Jogo chamado Elaboração de Jornais ou Revistas na Escola (p.121) em que apresenta sugestões de trabalhos para essa atividade, explicando que este jogo pode ser feito em forma de Jornal cooperativo ou Jornal competitivo. O autor propõe temas da área de química, mas temas de astronomia podem ser trabalhados também. Outro recurso que pode ser usado para o ensino de astronomia é a Construção de um Simulador de Densidade (p.124). Este jogo pode ser usado para ensinar a respeito de modelos de foguetes usados no ensino de astronomia e para fazer relação com cálculos que remetem à densidade. O Jogo Desenvolvimento de História em Quadrinhos apresenta conceitos científicos e, no âmbito da astronomia, podem ser desenvolvidos trabalhos pelos alunos. No livro, encontra-se o link para acesso aos jogos do autor. 
Indicações de leitura, que abordam a respeito do ensino de ciências e astronomia, educação e jogo, são: Jogos na Educação - Criar, Fazer e Jogar, de Lopes (2001); Os Professores de Ciências e suas Formas de Pensar Astronomia, de Leite (2002); Uma Avaliação da Utilização de Jogos em Educação, de Lerner (1991); O Ensino e a Divulgação da Astronomia, escrito por Moreno (acesso em 2014); Rizzo (1996) que discorre sobre Jogos inteligentes: A construção do raciocínio na escola; e a obra Astro-Jogos: uma forma divertida de aprender astronomia, de Trevisan Sanzovo (2008).

Estes materiais, livros e recursos didáticos foram escolhidos para apresentação porque o primeiro livro Jogos para o ensino de Astronomia (MARTINEZ \& FERREIRA, et al. 2013) é uma literatura inédita na área de jogos no ensino de astronomia, e possui recursos que podem ser aplicados em sala de aula. $\mathrm{O}$ segundo livro, Ensino de Química (SOARES, 2008), foi visto porque alguns jogos presentes nele podem ser adaptados e transpostos para o ensino de astronomia.

As publicações que discorrem a respeito do ensino de astronomia são de grande valia para se entender a importância das aplicações de jogos com estudantes e para inspirar professores a utilizarem desta prática em sala de aula. Importante lembrar que todos os recursos que foram explicados são materiais didáticos que podem ser utilizados pelos professores. Um dos Jogos do primeiro livro citado, Jogo Perfil Astronômico, será explicado e é objeto de pesquisa deste trabalho. Ele pode ser usado como recurso didático para se ensinar astronomia a estudantes da educação básica.

\subsubsection{História do emprego do Jogo Perfil Astronômico}

No período da graduação em Licenciatura em Ciências Naturais, a autora criou um recurso didático chamado Jogo Perfil Astronômico. O Jogo foi baseado na metodologia do Jogo Perfil da Grow. O Perfil Astronômico está disponibilizado no livro de Bretones (2013) e na segunda edição do livro, Bretones (2014), e a primeira versão que é anterior às publicações dos livros, está disponibilizada para download e impressão em um website ${ }^{1}$, em que também há um espaço para recebimento de sugestões e críticas

https://sites.google.com/site/kitastronomiaunb/ 
sobre o material apresentado. O Jogo é composto por tabuleiro e cartas que foram criados pela autora.

O Jogo Perfil astronômico foi apresentado para professores em diversas ocasiões, tais como:

a) no Simpósio Nacional de Educação em Astronomia (SNEA), que ocorreu no Rio de Janeiro em julho de 2011;

b) na Reunião Anual da Sociedade Astronômica Brasileira (SAB), que ocorreu em São Paulo em setembro de 2011;

c) no Encontro Nacional de Educação em Ciências (ENEC), que ocorreu em Portugal no mês de setembro/outubro de 2011;

d) nos encontros de Iniciação Científica da FUP, no início de 2012;

e) no Encontro de Ciências da FUP, em 2012;

f) na palestra sobre Astronomia, na Semana de Ciências da Universidade de Brasília, em 2012;

g) no curso sobre recursos didáticos de Astronomia, na Universidade de Brasília, no campus de Planaltina, durante o $1^{\circ}$ encontro de Iniciação Científica Júnior, em 2012;

h) na Semana de Ciência e Tecnologia de Brasília, na Universidade de Brasília - Campus Planaltina, em 2012;

i) nas aulas de disciplinas como 'Universo' e 'Ensino de Ciências', na Universidade de Brasília, entre os anos de 2011 e 2014;

j) nas aulas em três escolas públicas do Distrito Federal, para os $6^{\circ}, 7^{\circ}$, $8^{\circ}, 9^{\circ}$ do Ensino Fundamental e $1^{\text {a }}$ série do Ensino Médio, em 2013 e 2014;

k) em algumas escolas do Distrito Federal com o projeto Escola nas Estrelas, assim como em outras escolas do Entorno, como parte de minicursos de Astronomia que foram realizados nas mesmas cidades, entre os anos de 2011 e 2014.

O Jogo foi apresentado para diferentes audiências e despertou grande interesse no que diz à geração de muitas perguntas sobre ciências e astronomia. Durante essas aplicações, as contribuições foram de grande valia para perceber as vantagens e desvantagens do trabalho. O que é destacado é que ele foi aproveitado por grupos de 
pessoas na faixa etária de 09 até 90 anos. O tema propicia curiosidade e ampla participação no Jogo proposto. Percebemos novas interpretações do conhecimento por parte do jogador, que passa a observar a prática das ciências naturais como uma atividade inspiradora para o pensar e para o descobrir, diferente do que se vê no dia-adia em algumas salas de aula.

No momento do Jogo, houve participação dos alunos, que se demonstraram motivados a aprender enquanto jogavam. Lembranças de desenhos animados, como o Bob Esponja, foram vistas, por exemplo, quando se dizia de uma carta que abordava a respeito do planeta Netuno. Na primeira dica, que falava que este local tinha relação com Tritão, eles responderam Netuno e disseram que viram essa informação em um dos personagens do desenho Bob Esponja. Conseguiram relacionar os dados da carta com informações que viram antes do Jogo.

A partir do ponto de vista da autora e pela observação informal durante as aplicações, tornou-se necessária uma investigação mais cuidadosa, para se perceber realmente as contribuições do Jogo para o ensino.

\subsubsection{Descrição do Jogo Perfil Astronômico}

O Jogo Perfil Astronômico possui sessenta e três cartas, quatro peões e um tabuleiro. As opções de tabuleiro são mostradas na figura 10, na figura 11 e na figura 12, e um exemplo de carta é mostrado na figura 13. Como peões, podem ser usados materiais criados pelos jogadores ou pequenos paper-sciencecrafts (modelos de papel temáticos), inclusive modelos dos planetas. Eles servem para indicar a evolução, no jogo, de cada um dos 4 possíveis jogadores ou 4 grupos de jogadores. 


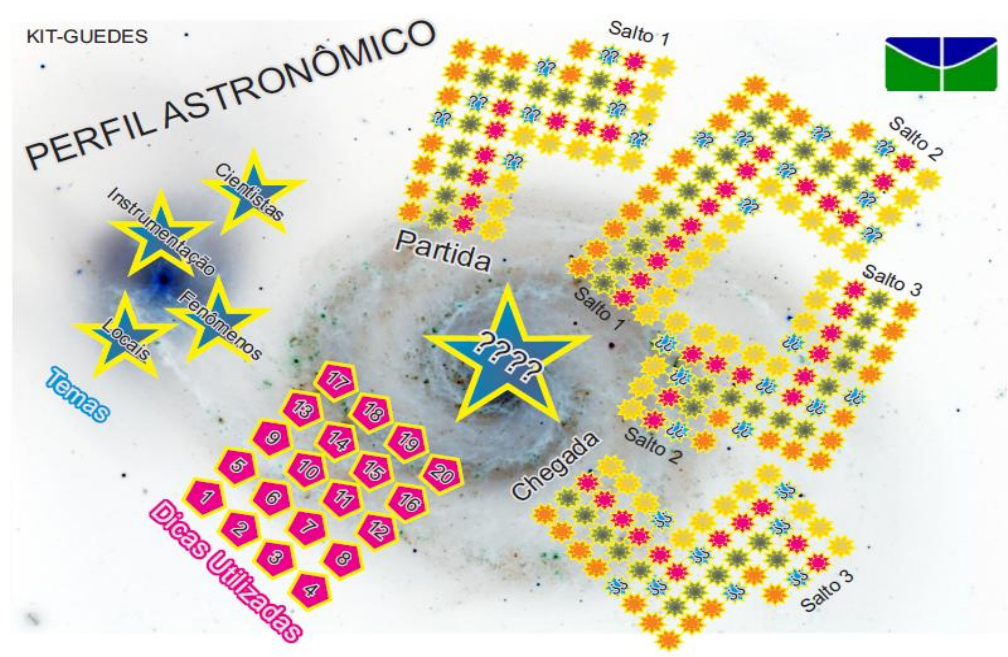

Figura 10 - Tabuleiro do Jogo perfil Astronômico

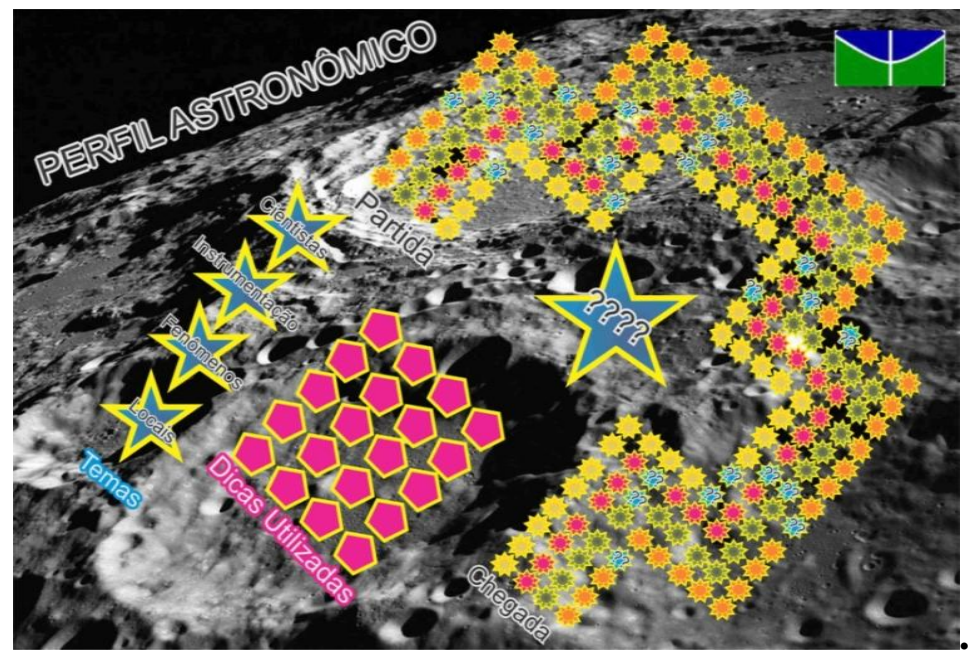

Figura 11 - Opção de tabuleiro do Jogo perfil Astronômico.

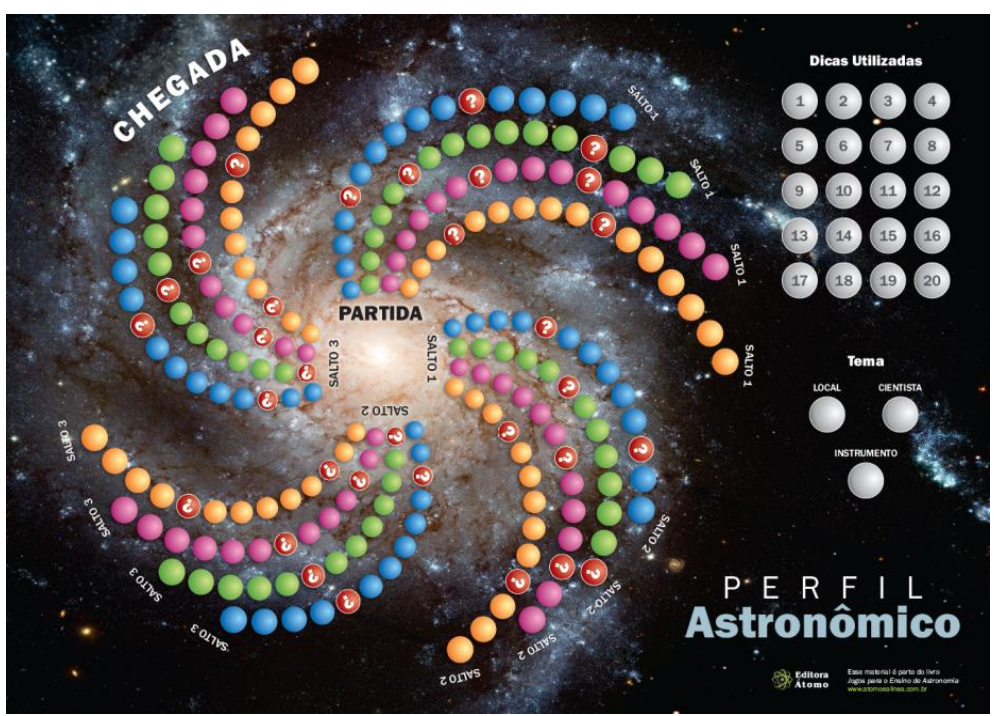

Figura 12 - Opção de tabuleiro do Jogo Perfil Astronômico. FONTE: Bretones (2013). 


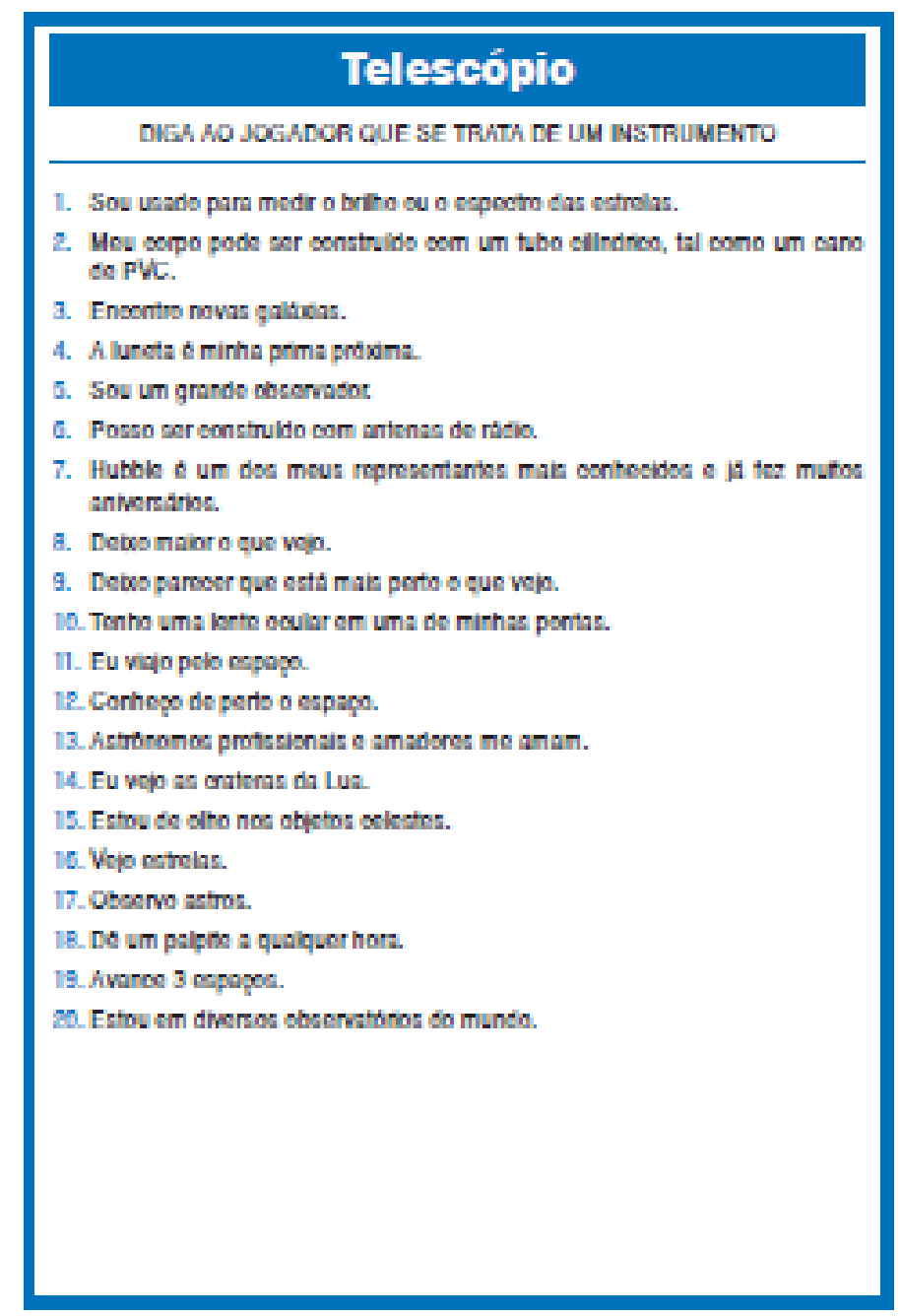

\section{Figura 13 - Exemplo de carta do Jogo Perfil Astronômico, da classificação Instrumento FONTE: Bretones (2013).}

O Jogo Perfil Astronômico poderá ter até quatro pessoas envolvidas na partida, ou, se organizado em grupos, quatro grupos, sendo um grupo para cada peão, em uma proposta de jogo coletivo.

Tem três tipos de tabuleiros apresentados porque, de acordo com as aplicações do Jogo, ele foi sendo modificado, mas pode-se escolher qualquer um deles para jogar, o percorrendo todo ou em partes, conforme o propósito do professor e tempo de aulas.

A dinâmica do Jogo é a seguinte: um dos jogadores sorteia uma carta, sem olhála, ou o professor a escolhe de acordo com o que quer trabalhar com seus alunos. Esta carta conta com vinte dicas (Figura 13) acerca de um tema, que pode estar relacionado com uma pessoa, um lugar ou um instrumento relevante na história da Astronomia. O tema Cientista pode ser algum estudioso, cientista relacionado à Astronomia; Lugar pode ser um corpo celeste ou mesmo algum lugar físico na Terra que tem relação com 
Astronomia; Instrumento é um grupo representado por objetos usados na Astronomia para alguma observação ou estudo.

O jogador ou grupo de jogadores são convidados a dizer um número entre um (1) e vinte (20), que corresponderá a uma dica, que será lida por quem estiver administrando o Jogo (será explicado adiante). Assim que ouvir a dica, ele poderá responder ou passar a vez. Caso acerte, ele avançará no tabuleiro um número de casas igual ao número de dicas não utilizadas. Se errar, não anda. Caso passe a vez, outro jogador é convidado a falar o número de uma dica, e assim por diante. Ganha o Jogo quem percorrer todo o tabuleiro ou o percurso escolhido, anteriormente, pelo grupo de jogadores.

No entanto, para alegrar a dinâmica, entre as vinte dicas de cada carta, algumas são, na verdade, armadilhas que levarão o candidato a perder sua vez ou andar para trás ou para frente, no tabuleiro. Pode, também, receber um Palpite para usar a hora que quiser mesmo que esteja na vez do outro grupo. Tendo este Palpite, pode-se responder o que é a carta, caso saiba. Cabe lembrar que, ao caminhar, caso o jogador ou grupo de jogadores pare em cima de alguma interrogação que há no tabuleiro, ganham uma carta para responder individualmente ou em grupo, porém poderão escolher seis dicas e responder apenas uma vez. Caso acertem na primeira dica andam seis casas, na segunda andam cinco, na terceira andam quatro, na quarta andam três, na quinta andam duas, e na sexta andam uma casa.

Em sala de aula, o Jogo é muito útil para ser aplicado em grupos. Nesse caso, a cada partida um grupo coordena o Jogo, fazendo as perguntas e depois o grupo que está do lado esquerdo mobiliza a segunda partida, e assim por diante. Cabe ressaltar que o grupo que está administrando as dicas e fornecendo-as aos jogadores andará o quanto os outros três grupos houverem pedido de dica. De forma individual, a metodologia é a mesma, no sentido de que a pessoa que está ao lado esquerdo é quem coordena cada partida. Outra forma de coordenar o Jogo é estando o professor como aplicador. Esta é a maneira mais utilizada quando o trabalho é aplicado em sala de aula. Os grupos respondem, cada um na sua vez, sobre a mesma carta.

O grupo ou indivíduo que acertar caminhará o resultado encontrado a partir de uma subtração, que é o número máximo de dicas de cada carta (20), menos o número de dicas que já foram pedidas. Exemplo: 20 - 11 = 9 (número de dicas de uma carta menos a quantidade de dicas que já foram pedidas pelo grupo. O grupo que acertou depois da 
décima primeira dica caminhará nove casas do tabuleiro, e o coordenador do jogo (se não for o professor) caminhará o número de dicas que foram pedidas até acertar (11)).

O conjunto de cartas do Jogo que trata do tema "Cientista" permite relacionar o personagem histórico, com suas características físicas, seu lugar e sua época ou com os seus feitos, suas realizações. E mais, como este mesmo cientista pode estar ligado a um lugar ou a um instrumento, o jogador poderá tecer as conexões e fixar o conhecimento.

Com o conjunto de cartas do Jogo que trata do tema "Instrumento" torna-se possível lembrar sobre algum objeto utilizado na Astronomia, aprender sobre ele e perceber a praticidade dessa área.

O outro conjunto de cartas do Jogo que trata do tema "Local" possibilita o aprendizado a respeito de tamanhos dos corpos celestes, o que já é conhecido sobre cada um, sua localização no céu ou mesmo na Terra. É possível tecer conexões com o que homem já conhece e quer conhecer.

Foi percebido que, mesmo um jogador não sabendo muito sobre um tema da carta, ao jogá-la, aprende mais sobre ele e ouve novas informações. Existem dicas, nas cartas, que ajudarão a descobrir sobre o tema, pois por meio dela pode-se usar o raciocínio lógico, relacionar com os conhecimentos já adquiridos e concluir a resposta. A cada jogada, de maneira geral, aprende-se mais em relação ao início do jogo, pois se entende diversas informações a respeito de cada carta.

A partir do Jogo é possível ter acesso a novos dados e conceitos, e o Jogo pode possibilitar uma visão mais crítica para quem o joga, gerando capacidades para interpretar, analisar e comunicar sobre conhecimentos de forma diferenciada de quando iniciou o Jogo.

As cartas do jogo têm o intuito de contribuir para o desenvolvimento de parte do pensamento científico, em seus conteúdos atitudinais, procedimentais, conceituais, em alunos que o jogarão. Entendendo que o pensamento científico é um excelente caminho para que os indivíduos construam uma diferente percepção do mundo, pode-se aplicar um Jogo que propicie parte desta aprendizagem. O conhecimento que eles já possuem é de grande valia para que desenvolvam novas maneiras de interpretar o que veem. Foi observado que o Jogo Perfil Astronômico possibilita esta ligação entre o que já se sabe e os novos conteúdos.

Nas cartas do Jogo existem dados ou dicas, e são significados que ao serem concatenados formam a ideia para se descobrir o elemento da carta, que pode ser um 
instrumento, cientista ou local. Ao ouvir as dicas, pode-se descobrir sobre o que a carta aborda.

É esperado, no que concerne ao Jogo, que estimule a curiosidade pelo tema astronomia; auxilie como nova ferramenta de trabalho para professores desenvolverem o tema astronomia e temas correlatos, como a física, biologia, química; promova a interação entre os estudantes no sentido de uma busca coletiva pelo conhecimento; estimule a construção do conhecimento.

Com o Jogo será possível que os alunos desenvolvam novas maneiras de pensar e tenham acesso a novas formas de conhecimento de maneira idiossincrática, única a cada vez. As cartas podem ser escolhidas de maneira fortuita ou a critério do professor para trabalhar determinado tema de aula, e as dicas de uma carta podem aparecer em uma ordem aleatória, dentre vinte possibilidades. Cada partida será estruturada de acordo com o professor, ou, se o professor permitir, a critério dos grupos de jogadores, no que concerne ao tempo de jogo, cartas a serem jogadas, casas do tabuleiro a serem utilizadas. Em suma, este jogo permitirá que nasça uma face para cada uma das partidas.

"Compreender algo envolve maior envolvimento pessoal, maior compromisso com o aprendizado, do que seguir cegamente alguns passos marcados, obedecendo ao mandato de algumas instruções". (POZO \& CRESPO, 2009, p. 86)

Mais do que seguir regras, o jogador está diante de uma possibilidade de pensamentos e conhecimentos novos. Existe a afirmação de que para que alguém aprenda novos conhecimentos, quando há a vontade de aprender é mais fácil ensinar. Mas quando não há tanta vontade, é impossível ensinar? Acreditamos que não. Acreditamos que, pelo envolvimento em um jogo, o aluno pode se motivar a aprender.

Há a discussão de que alguns alunos não aprendem a ciência que lhes é ensinada. Mas o professor está presente para auxiliá-lo neste desenvolvimento, guiando-o no caminho do aprender e do saber. Este Jogo é um recurso, e pode ser um auxílio para que o professor, em sala de aula, atinja seus objetivos.

Nossa investigação foi no sentido de saber se o Jogo Perfil Astronômico pode desenvolver conteúdos atitudinais e procedimentais, além dos conceituais. Para isto, a análise do Jogo Perfil Astronômico foi desenvolvida concomitante a uma unidade didática, e tem como objetivo avaliar se o Jogo é capaz de gerar conteúdos atitudinais e procedimentais. Vale ressaltar que esta Unidade didática é uma sugestão para se 
trabalhar com o Jogo em sala de aula. Outros professores podem se direcionar por esta maneira de aplicar o Jogo, se o objetivo for desenvolver atitudes e procedimentos com os alunos, ou com outras perspectivas. As Regras do Jogo Perfil Astronômico estão na Unidade didática. 
...Sem ciência, sem saber, sem habilidades ou conhecimentos não há nenhuma liberdade. Isso envolve a aquisição, a internalização do conhecimento, mas também o desenvolvimento de várias funções mentais.

É necessário então desenvolver métodos de ensino que permitam aos aprendizes desenvolver suas habilidades $\mathrm{e}$ capacidades que privilegiem a análise e compreensão de uma situação, não simplesmente dar ênfase a acumulação de uma grande quantidade de conhecimento. Mesmo em dificuldades, cada aluno poderá aprender, crescer e adquirir conhecimento...

(Fátima Verdeaux) 


\section{METODOLOGIA DA PESQUISA}

\subsection{Conteúdos conceituais, atitudinais e procedimentais}

Segundo Pozo e Crespo (2006) "Os alunos devem, na verdade, aprender a conviver com diversidade de perspectivas, com a relatividade das teorias, com a existência de interpretações múltiplas de toda informação. E devem aprender a construir seu próprio julgamento ou ponto de vista a partir de tudo isso" (p. 24). Criar, avaliar e conjecturar um conhecimento pode fazer parte do pensar cientificamente e possibilita que os alunos tenham esta maneira própria de agir e de construir um julgamento próprio do mundo em que vivem. Para isso, parte da realidade vista nas escolas precisa ser modificada, em seu contexto de ensino.

Continuando com a ideia de Pozo \& Crespo (2006), os alunos se mantêm muito afastados da tentação da árvore da ciência, e quando provam seus suculentos frutos não parecem desfrutar muito deles. Essa perda de sentido do conhecimento científico não só limita sua utilidade ou aplicabilidade por parte dos alunos, mas também seu interesse ou relevância. Quando se investe no desenvolver do pensamento científico em seus aspectos procedimentais e atitudinais, além dos conceituais, a realidade escolar pode ser em parte alterada. Cabe ressaltar que a árvore da ciência pode ser mirada por outro ângulo para que se reverbere a respeito da verdadeira ciência, e para que não seja observada de forma deturpada, como é vista por algumas pessoas.

Os conhecimentos científicos precisam ser aplicados, precisam ser vistos em compasso com os conteúdos procedimentais do currículo de ciências (POZO \& CRESPO, 2006). Elaborar um gráfico a partir de alguns dados ou observar, apuradamente, por meio de um telescópio, são exemplos de conteúdos procedimentais. Por vezes os alunos do Ensino Fundamental e do Ensino Médio sabem fazer atividades, mas não compreendem o sentido do que estão fazendo e, portanto, não conseguem aplicá-las em novas situações.

Essas dificuldades tornam-se evidentes, principalmente, na resolução de problemas, que os alunos tendem a enfrentar de um modo repetitivo, como simples exercícios rotineiros, em vez de encará-los como tarefas abertas que exigem reflexão e tomada de decisões (CABALLER \& OÑORE, 1997; POZO \& CRESPO, 1994). Com os conteúdos procedimentais, os alunos aplicam seus conhecimentos a novas situações e 
tendem a compreender os problemas com possíveis soluções, que eles têm a capacidade de criar.

Ainda a respeito dos procedimentos, sabe-se que não são ensinados como os conteúdos conceituais. A forma de explicar e escutar não é o caminho para se obter êxito no aprendizado de conteúdos procedimentais. Por conseguinte, é ideal utilizar técnicas e estratégias para obter este sucesso. Para clarear estes significados, Pozo \& Crespo (2006) afirmam que "a técnica seria uma rotina automatizada devido à prática repetida, e as estratégias envolvem um planejamento e uma tomada de decisão sobre os passos que serão seguidos [...] As estratégias seriam compostas, portanto, de técnicas, e envolveriam usá-las deliberadamente em função dos objetivos da tarefa" (POZO \& CRESPO, 2006, p.08).

O conteúdo procedimental está mais relacionado à ação fazer, no sentido de se construir algo. Com a aquisição de procedimentos, há o objetivo de participar do desenvolvimento de uma tarefa por meio da técnica para se desenvolver uma estratégia. Um aluno tem o potencial de formular estratégias, utilizando-se de técnicas, e exemplos pertinentes desse fato são a capacidade do aluno para resolver um exercício de sala, responder às questões do cotidiano e resolver problemas, dentro e fora da escola, por meio de estratégias formuladas por ele, embasadas em técnicas que o mesmo conhecia. Os conteúdos procedimentais podem ser entendidos como sinônimo de habilidades concomitante à estratégias. Coll (1996) afirma que

procedimentos são habilidades, estratégias e outras formas de ação que articulam esses conteúdos no triângulo - objetivos, resultados e os meios de alcançá-los - fora do qual nenhuma aprendizagem da criança ou intenção pedagógica do professor serão concretizadas. (COLL, 1996, p.13)

Como parte do pensamento científico, há os conteúdos conceituais, que não são apenas um resultado de transmissão de palavras, é um processo. A formação de conceitos se faz pelo uso das palavras, por combinações entre operações mentais, alcançando-se a síntese ou conceito, que Sampaio e Silva (1998) afirmam que se persegue para que os alunos possam chegar lá. Estes conteúdos conceituais são os mais vistos, diariamente, nas escolas, pois é adequado à maneira de avaliação que se faz. Quando se fala em conceitos, sabe-se: 
Conceitos correspondem ao compromisso científico da escola: transmitir o conhecimento socialmente produzido e que, atualmente, melhor responde à nossa necessidade de explicar leis da natureza ou da vida social, bem como, por extensão, resolver, pela tecnologia, questões de sobrevivência (biológica, cultural, social). (COLL, 1996, p.13)

Os autores Pozo \& Crespo (2006) enfatizam sobre a maneira como, normalmente, são avaliados estes conhecimentos em ambientes de ensino:

"O que geralmente se avalia é o conhecimento conceitual e em menor medida, o procedimental, mas as atitudes dos alunos praticamente não são levadas em conta, talvez porque se encaixam mal no tradicional formato de prova”. (POZO \& CRESPO, 2006, p.25).

Segundo Pozo e Crespo (2006), as atitudes não têm sido objeto de ensino explícito. Vale ressaltar que as atitudes dos estudantes se configuram em seus valores, sua forma de se comportar na sala de aula e fora dela, e como não costumam ser ensinadas em sala, de forma geral, perfaz uma das principais dificuldades para o ensino. Pozo e Crespo (2006) completam e dizem que dessa maneira, os professores dizem a respeito das atitudes dos alunos quando tem deficiências para ensinar: "Há falta de educação dos alunos, falta de interesse pela matéria Ciências Naturais". Entende-se ser necessário desconstruir estas falas docentes ou ao menos reduzi-las, pois a Ciência merece mais destaque em sala de aula, e a má formação em conteúdos atitudinais, no que concerne aos alunos, não pode ser o fator limitante para o desenvolver da ciência. Referente aos conteúdos atitudinais, Coll (1996) põe o significado como sendo correspondente ao compromisso filosófico da escola. Discorre um pouco mais: "Atitudes devem promover aspectos que nos completam como seres humanos, que dão uma dimensão maior, que dão razão e sentido para o conhecimento científico" (COLL, 1996, p.13). Os conteúdos atitudinais que podem ser incorporados pelos estudantes devem ser protagonistas junto aos conteúdos conceituais e procedimentais. É uma tríplice união que possibilita, de forma natural, o aparecimento e desenvolvimento do pensamento científico.

Neste caminhar, surge um objetivo: Identificar até que ponto o Jogo Perfil Astronômico auxilia para o desenvolvimento de aspectos do pensamento, em seus conteúdos atitudinais e procedimentais, além dos conceituais. A pergunta base era se o Jogo Perfil Astronômico podia desenvolver conteúdos atitudinais e procedimentais. 
Foram realizadas aplicações, e cada forma de aplicação demandou um tempo e inserção efetiva do professor e participantes, estudantes de licenciatura em Ciências Naturais.

\subsection{Categorias de Conteúdos Atitudinais e Procedimentais no Ensino de Astronomia}

Com o intuito de avaliar se o Jogo Perfil Astronômico pode desenvolver conteúdos atitudinais e procedimentais, foram criadas categorias, a partir da literatura, que nos permitissem analisar a participação dos estudantes durante o jogar. O trabalho necessitou da elaboração de categorias a partir dos conteúdos atitudinais e procedimentais a partir da discussão teórica de Pozo e Crespo (2006). Foi construída uma tabela de categorias (tabela 2) que tem o propósito de mostrar a divisão dos conteúdos Atitudinais e Procedimentais que foi usada na análise no momento das aplicações do Jogo. Foi feita com base na tabela de categorias presente no livro de Pozo e Crespo (2006).

É necessário um meio para ajudar ao professor que tem o intuito de formar um aluno com potencial para internalizar e expor esses conhecimentos, pois esses conteúdos contribuem para o desenvolvimento do pensamento científico. É evidente que o propósito de um aparato criado para contribuir para o desenvolvimento do pensamento científico é promover esses conteúdos ou parte deles.

Foi possível validar instrumentos de coleta de dados em aplicações que foram realizadas quando a autora estava participando em eventos. Ao final deste trabalho, está proposta uma Unidade didática.

Cabe lembrar que os conteúdos conceituais podem ser desenvolvidos, por exemplo, por meio de leituras que um aluno faz, por meio de aulas expositivas, palestras, filmes, revistas, dentre outros. Explicitando os conteúdos procedimentais, é de grande valia ressaltar que, assim como as atitudes, os procedimentos não foram contemplados como deveriam nos currículos de ciências; os procedimentos não são vistos como algo comum em sala de aula, conforme afirmam Pozo e Crespo (2006). Pozo e Crespo (2006) relatam que os conteúdos atitudinais e procedimentais não são explicitados nos currículos de ciências, que priorizam os conteúdos conceituais, dificultando que os alunos aprendam ciências e sua forma de pensamento e de construção.

Na tabela 2 são mostrados os conteúdos Atitudinais e Procedimentais de acordo com Pozo e Crespo (2006), pois estes conteúdos são nosso objetivo de investigação. 
Tabela 2 - Tabela de Categorias do pensamento científico - Conteúdos Atitudinais e Procedimentais do Ensino de Ciências

\begin{tabular}{|c|c|c|}
\hline \multirow{3}{*}{$\begin{array}{l}\mathrm{A} \\
\mathrm{T}\end{array}$} & \multirow{6}{*}{ Em relação à Ciência } & Discurso científico de outros discursos \\
\hline & & Atitude reflexiva e crítica \\
\hline & & Visão relativista e histórica \\
\hline 1 & & Forma de fazer perguntas \\
\hline U & & $\begin{array}{c}\text { Diferenciar a abordagem científica de } \\
\text { outras abordagens }\end{array}$ \\
\hline D & & Gosto pelo rigor e precisão no trabalho \\
\hline$N^{1}$ & \multirow{2}{*}{$\begin{array}{c}\text { Em relação ao papel social } \\
\text { da ciência }\end{array}$} & Cooperação \\
\hline A & & $\begin{array}{c}\text { Discussão crítica da aplicação da ciência na } \\
\text { sociedade }\end{array}$ \\
\hline \multirow{2}{*}{$\mathrm{S}$} & \multirow{2}{*}{$\begin{array}{c}\text { Em relação à } \\
\text { aprendizagem da ciência }\end{array}$} & Enfoque superficial (repetitivo) \\
\hline & & Enfoque profundo (busca de significado) \\
\hline \multirow[b]{3}{*}{$\mathrm{P}$} & \multirow{4}{*}{ Aquisição da informação } & Observação \\
\hline & & Seleção de informação \\
\hline & & Busca e captação da informação \\
\hline $\mathrm{O}$ & & Revisão e memorização da informação \\
\hline $\mathrm{C}$ & \multirow{2}{*}{$\begin{array}{l}\text { Interpretação da } \\
\text { informação }\end{array}$} & Modelagem \\
\hline $\mathrm{E}$ & & Decodificação ou tradução da informação \\
\hline \multirow{2}{*}{ D } & \multirow{3}{*}{$\begin{array}{l}\text { Análise da informação e } \\
\text { realização de inferências }\end{array}$} & Análise e comparação da informação \\
\hline & & Estratégias de raciocínio \\
\hline E & & $\begin{array}{l}\text { Atividades de investigação ou solução de } \\
\text { problemas }\end{array}$ \\
\hline $\mathrm{T}$ & \multirow{3}{*}{$\begin{array}{c}\text { Compreensão e } \\
\text { organização conceitual da } \\
\text { informação }\end{array}$} & Compreensão do discurso (escrito/oral) \\
\hline A & & Estabelecimento de relações conceituais \\
\hline $\mathrm{I}$ & & Organização conceitual \\
\hline \multirow{3}{*}{$\mathrm{S}$} & \multirow{3}{*}{$\begin{array}{l}\text { Comunicação da } \\
\text { informação }\end{array}$} & Expressão oral \\
\hline & & Expressão escrita \\
\hline & & Outros tipos de expressão \\
\hline
\end{tabular}


No estudo preliminar desta pesquisa, dentro de nossa hipótese foi possível perceber fatores do pensamento científico, conteúdos atitudinais, conceituais e procedimentais, enquanto alunos do curso de Licenciatura em Ciências Naturais jogavam o Perfil Astronômico. Esta validação com alunos de Ciências Naturais foi de suma valia para percebemos a necessidade de fazermos a pesquisa para auxiliar no desenvolvimento do ensino-aprendizagem.

Após a validação da tabela como instrumento de coleta de dados, durante nossa pesquisa, esses fatores do pensamento científico foram dialogados com os critérios da tabela 2, relacionando cada tópico com uma fala ou atitude de um estudante no momento do Jogo, ou mesmo com uma escrita colocada no questionário que foi aplicado. As falas e escritas apresentadas pelos alunos foram analisadas de acordo com os tópicos da tabela.

\subsection{Como foi a pesquisa - Local da pesquisa e público alvo}

O campus UnB Planaltina localiza-se no bairro Vila Nossa Senhora de Fátima, Planaltina/DF e possui trinta hectares. Utiliza-se de três prédios em funcionamento, além da Unidade de Ensino e Administração e a Unidade de Ensino e Pesquisa I (PROJETO POLÍTICO PEDAGÓGICO DO CURSO DE LICENCIATURA EM CIÊNCIAS, UnB, 2010).

A pesquisa piloto foi realizada junto aos estudantes do curso de Licenciatura em Ciências Naturais da Faculdade UnB Planaltina. Duas turmas do segundo semestre de 2012 participaram do Jogo, mas não foi aplicado nenhum questionário. Já no primeiro semestre de 2013, duas turmas da disciplina 'Ensino de Ciências', do $3^{\circ}$ semestre, que somavam 57 alunos foram selecionadas, e os estudantes contribuíram para o projeto ao participar do Jogo Perfil Astronômico e ao responder um questionário.

As aplicações do projeto piloto, que foram realizadas nas turmas de 'Ensino de Ciências' do curso de licenciatura em Ciências Naturais, aconteceram de forma concomitante, no sentido de que tiveram um papel importante em relação à outra, de uma turma comparada à outra, pois a maneira de aplicação foi semelhante e novas informações foram coletadas a cada partida do Jogo. Em suma, as maneiras de aplicar o Jogo desempenharam um papel importante para que a Tabela de Categorias (tabela 2) 
fosse adaptada, e para que fosse validada a ideia de investigar se o Jogo proporciona o desenvolvimento do pensamento científico, e como ele o proporciona. O questionário de avaliação do Jogo (anexo A) também foi validado nesta etapa. Ele teve o propósito de observar se os alunos aprendiam conteúdos conceituais, atitudinais e procedimentais.

Após a aplicação do material didático com os licenciandos em Ciências Naturais, do segundo semestre de 2013, houve uma resposta destes alunos de acordo com a coleta de dados. A Tabela de categorias auxiliou para se identificar como os conteúdos atitudinais e os conteúdos procedimentais podiam ser notados.

No âmbito da aplicação do Jogo e teste dos instrumentos de coleta de dados, a autora percebeu, ao fazer anotações e análise dos questionários, que com as cartas do Jogo Perfil Astronômico que têm o tema "Local", os conteúdos atitudinais e procedimentais são mais expressos, e, no tema "Instrumento", os conteúdos procedimentais e os conteúdos conceituais são mais expressos. O tema "Cientista" tende a propiciar o aparecimento dos conteúdos atitudinais e conceituais pelos alunos. Importante frisar que muitos dos exemplos usados, sobre conteúdos procedimentais, atitudinais e conceituais foram expressos pelos licenciandos em Ciências Naturais, por meio de suas falas e ações, enquanto jogavam o Perfil Astronômico. Essa forma de análise foi importante para a coleta de dados.

A validação foi importante para mudar a turma de aplicação do Jogo e para adequar algumas questões do questionário. Como o objetivo da pesquisa era saber se eram desenvolvidos os conteúdos atitudinais e procedimentais, foi visto que mudar a aplicação para a turma de 'Universo', em que se ensina Astronomia, seria melhor para que o Jogo ocorresse de uma maneira em que pudéssemos observar mais esses conteúdos. Os alunos tinham maior facilidade nos conteúdos conceituais e ficou mais fácil observar o desenvolvimento dos outros dois tipos de conteúdo. Participaram da aplicação do Jogo uma turma do turno diurno e outra turma do turno noturno referente à disciplina 'Universo'.

Então, duas turmas da disciplina 'Universo' do segundo semestre de 2013 participaram da análise desse trabalho, que será discorrida. Ressaltamos que os estudantes participantes foram escolhidos e informados sobre a pesquisa e, caso alguém não quisesse participar, teria o direito. Os estudantes participantes preencheram Termo de livre consentimento (anexo B), e carece saber que os dados tiveram tratamentos confidenciais. A coleta de dados foi composta de registro escrito em caderno de campo, gravação e fotos, assim como de questionário, que foi aplicado para as duas turmas de 
'Universo' do segundo semestre de 2013, e cada aluno respondeu em uma cópia do questionário. A autora pediu para outro professor aplicar o Jogo enquanto ela fazia os registros e anotações, porque foi percebido que, durante a validação dos instrumentos de coleta, a autora podia influenciar com o envolvimento no processo e poderia criar viés na pesquisa. Para garantir uma análise mais isenta, seria bom que outra pessoa aplicasse o Jogo e a autora observasse.

\subsection{Material desenvolvido}

Nos momentos em que o Jogo Perfil Astronômico foi aplicado nas escolas, em eventos e durante a graduação da pesquisadora, foi percebido na fala de alguns participantes que este Jogo possibilita a aprendizagem, diversão e concentração, sem que os jogadores percebam o tempo passar. Professores e alunos disseram que conseguem aprender novos conceitos e lembrar conceitos que aprenderam anteriormente. Notamos que as perguntas que foram feitas pelos estudantes acerca de astronomia eram importantes para se aproveitar. A partir das perguntas dos estudantes, a pesquisadora pensou uma forma de aplicação do Jogo com o objetivo de gerar, propiciar o pensamento científico, utilizando-se de mais fundamentação teórica em relação à própria função de um jogo e do pensamento científico.

Como surgiu a ideia de estruturar um material didático que facilitasse o processo de ensino-aprendizagem e que contribuísse para o desenvolvimento do pensamento científico, o jogo Perfil Astronômico foi observado como fonte importante para este objetivo. Para analisar o Jogo, foi criada a Tabela 2 de categorias de conteúdos atitudinais e procedimentais para avaliar o desenvolvimento do pensamento científico, a partir da fundamentação teórica de Pozo \& Crespo (2006), conforme apresentamos no item 4.2 deste trabalho.

A outra etapa teve como objetivo formular uma Unidade didática (apêndice A) para que se aplique o Jogo com o intuito de propiciar os conteúdos atitudinais, procedimentais e conceituais.

A Unidade didática apresenta uma maneira de aplicar o Jogo Perfil Astronômico que facilite o desenvolvimento do pensamento científico, mas pode ser adequada, conforme os objetivos de quem aplicará. 
O Jogo Perfil Astronômico e a Unidade didática estão sendo disponibilizados ao meio escolar e científico por meio deste trabalho, também em site e livro.

\subsection{Coleta e análise de dados}

O trabalho constou de uma pesquisa com abordagem qualitativa dos dados coletados. A autora está envolvida no processo de aplicação da pesquisa, investigando o comportamento dos alunos e procurando identificar a aquisição de conteúdos atitudinais e procedimentais. Para clarear o conceito de pesquisa qualitativa, Bauer \& Gaskell (2000) afirmam que pesquisa qualitativa lida com interpretações das realidades sociais. Strauss e Corbin (2008) dizem que

a pesquisa qualitativa se refere a qualquer tipo de pesquisa que produza resultados não alcançados através de procedimentos estatísticos, e pode se referir à pesquisa sobre a vida das pessoas, experiências vividas, comportamentos, emoções e sentimentos, e também à pesquisa sobre funcionamento organizacional, movimentos sociais, fenômenos culturais e interação entre nações. (STRAUSS \& CORBIN, 2008)

Ainda discorrendo a respeito de pesquisa qualitativa e seus processos, Conceição (2011) define como:

A pesquisa qualitativa começa com a disposição de se investigar determinada área. Os dados são coletados por meio de entrevistas, documentos e outros. Através desses dados, criam-se as ideias e hipóteses por intermédio de raciocínio indutivo. A pesquisa qualitativa não pode ser repetida inúmeras vezes, produzindo sempre os mesmos resultados. Seu poder reside na validade, ou seja, em o quanto está próxima à verdade. Ela não é estanque e limitada e depende muito da experiência subjetiva dos pesquisadores e dos pesquisados. (CONCEIÇÃO, 2011)

Em nossa pesquisa qualitativa, os alunos do segundo semestre de 2013 já conheciam astronomia porque estavam estudando na disciplina 'Universo', e terem um domínio dos conteúdos conceituais facilitou para que se observasse o desenvolvimento 
dos conteúdos atitudinais e procedimentais. O questionário realizado com eles foi importante para observar quais aspectos do Jogo podiam ser melhorados, para observar se os estudantes aprenderam, para verificar como eles avaliaram a importância do jogo, da aplicação do Jogo Perfil Astronômico no ensino fundamental e para perceber se eles consideraram importante o lúdico e o ensino de astronomia.

O registro escrito foi realizado em um caderno de campo em que foram registradas as falas dos estudantes durante a realização do Jogo, e foram relatadas ações consideradas como relevantes no que diz aos objetivos do trabalho. A gravação foi de som e de vídeo, de forma que em um tempo seguinte as falas foram transcritas, anotadas, possibilitando revisões do que ocorrera em sala. As fotos foram tiradas com o propósito de registrar comportamentos dos alunos no decorrer da aplicação do jogo.

A aplicação do Jogo Perfil Astronômico foi realizada, por um professor doutor na área de física, em duas turmas do segundo semestre do curso de licenciatura em Ciências Naturais, na disciplina 'Universo', uma do turno diurno e outra do turno noturno, no dia 04 de setembro de 2013.

Foi analisado o papel do Jogo Perfil Astronômico para o desenvolvimento dos aspectos atitudinais e procedimentais, para seu uso posterior nas séries finais do ensino fundamental. Foi analisado, também, se os futuros professores de ciências conseguem enxergar o jogo como ferramenta de ensino e se na avaliação dos futuros professores os objetivos do Jogo foram atingidos. 
Só razão é fórmula. Só emoção é lágrima. Razão e emoção podem virar sabedoria.

(Paulo Brito) 


\section{RESULTADOS E DISCUSSÕES}

\subsection{Análise dos questionários}

A disciplina 'Universo' foi escolhida porque é ofertada no segundo semestre do curso de licenciatura em Ciências Naturais, no momento em que o aluno já se localiza no curso e tem noções de física e de astronomia. Ele tem a base e o pensamento de ser professor, sabe que está em uma licenciatura e possivelmente entende seu papel como futuro professor. O propósito era que o Jogo Perfil Astronômico fosse avaliado com estes jovens estudantes que já sabiam conceitos da área de Astronomia. As turmas do turno diurno e do turno noturno possuíam cinquenta e quatro alunos, no total.

Em outras aplicações, percebemos que o Jogo desenvolvia mudanças em alunos do ensino fundamental e médio, mas era necessário observá-lo em outro contexto, com futuros professores que poderiam aplicar este Jogo em sala de aula e com a participação deles era possível analisar a possibilidade do desenvolvimento de parte do pensamento científico.

O questionário que foi aplicado (anexo A) contém oito questões e teve o propósito de saber se os alunos aprenderam, o que aprenderam e como aprenderam. Por meio do questionário também foi possível identificar quais critérios foram escolhidos pelos alunos, no que diz respeito às características que o Jogo desenvolve, que se encaixavam dentro dos conteúdos atitudinais, procedimentais e conceituais. Um dos objetivos foi verificar se o aluno, como futuro professor, tinha a capacidade de apontar as vantagens e desvantagens do Jogo e dizer se jogos de forma geral e também a Astronomia eram importantes para alunos do ensino fundamental e médio. $\mathrm{O}$ questionário foi respondido depois da aplicação do Jogo realizada pelo professor, nas turmas da disciplina 'Universo' do segundo semestre de 2013.

Os resultados que obtivemos a partir dos questionários foram analisados à luz da tabela 2 e discutidos em seguida, mas também apresentamos alguns dados em gráficos, facilitando a visualização e discussão dos resultados. 
Pergunta 1 - Em qual semestre e ano você ingressou no curso de licenciatura em Ciências Naturais?

Essa questão foi feita com o objetivo de se observar em qual período da faculdade o aluno estava. Quando ele está no primeiro semestre está estudando as disciplinas: 'Filosofia e Sociologia' da Educação, 'Sistema Educacional Brasileiro' e 'Natureza e Energia' (da área de Física). Também está se adequando ao meio acadêmico, pois acabou de sair do ensino médio. Apenas um (01) aluno, do total das turmas, pertencia a este semestre.

- Trinta e sete (37) alunos pertenciam ao segundo semestre, quando é visto a disciplina 'Bases Psicológicas', em que se estudam algumas teorias relacionadas ao ensino de Ciências, e a disciplina 'Universo' em que se estuda Astronomia. Pode-se afirmar que já possuem noções pedagógicas. Ele já tem noções das áreas de Física e de Astronomia e tem a base e o pensamento do que é ser professor;

- Treze (13) alunos estavam no terceiro semestre do curso e cursavam as disciplinas 'Ensino de Ciências' e 'História e Filosofia da Ciência'. O estudante também já tem acesso ao conhecimento das ciências e às possíveis formas para ensinar;

- Dois (02) alunos que pertenciam ao quarto semestre e um (01) que estava no sexto semestre, que já possuem uma visão mais estruturada dos fundamentos pedagógicos e do que é ser professor.

$\mathrm{Na}$ turma do turno diurno participaram 26 alunos e na turma do turno noturno participaram 28 alunos. No que se refere à primeira turma que participou da pesquisa, do turno diurno, a partir da Figura 14 pode-se analisar que treze pessoas ingressaram no primeiro semestre de 2013, dez no segundo semestre de 2012, dois no primeiro semestre de 2012 e um no primeiro semestre de 2011. 


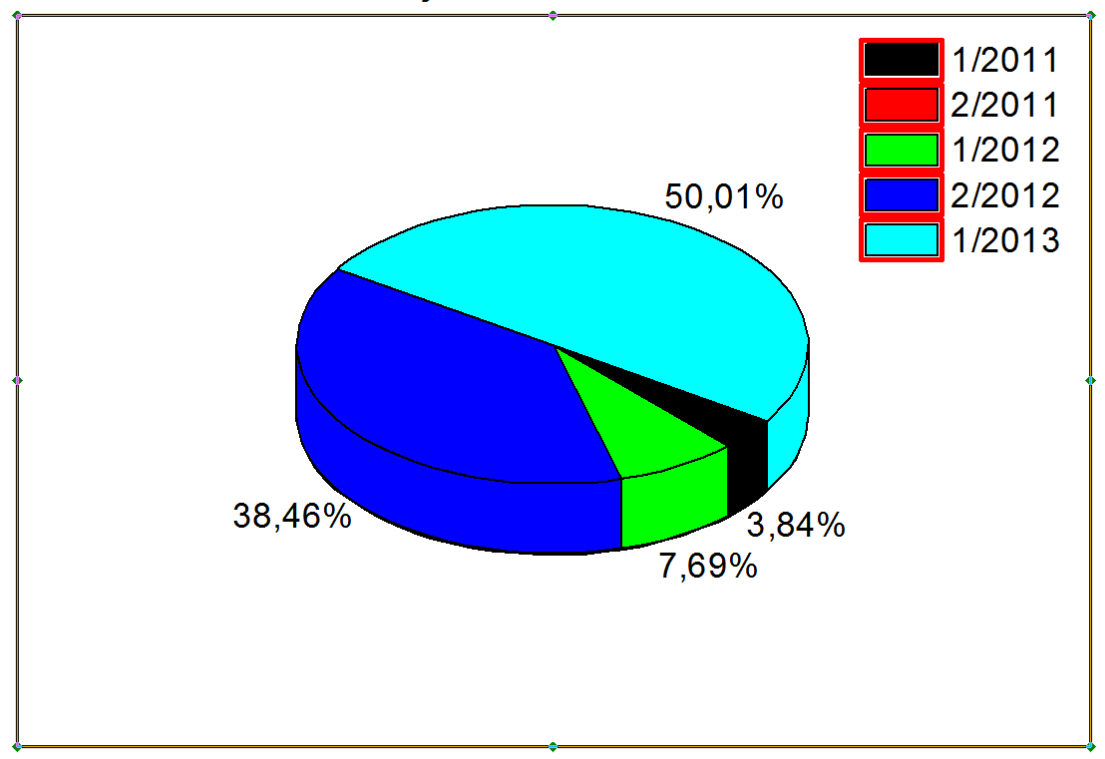

Figura 14 - Em qual semestre e ano o senhor ingressou no curso de licenciatura em Ciências Naturais?

No que refere à segunda turma que participou da pesquisa, do turno noturno, as porcentagens da Figura 15 mostram que:

- $86 \%$ (vinte e quatro pessoas) ingressaram no primeiro semestre de $2013,11 \%$ (três) no segundo semestre de 2012, e 3\% (uma pessoa) no segundo semestre de 2013.

Distribuição dos alunos - Noturno

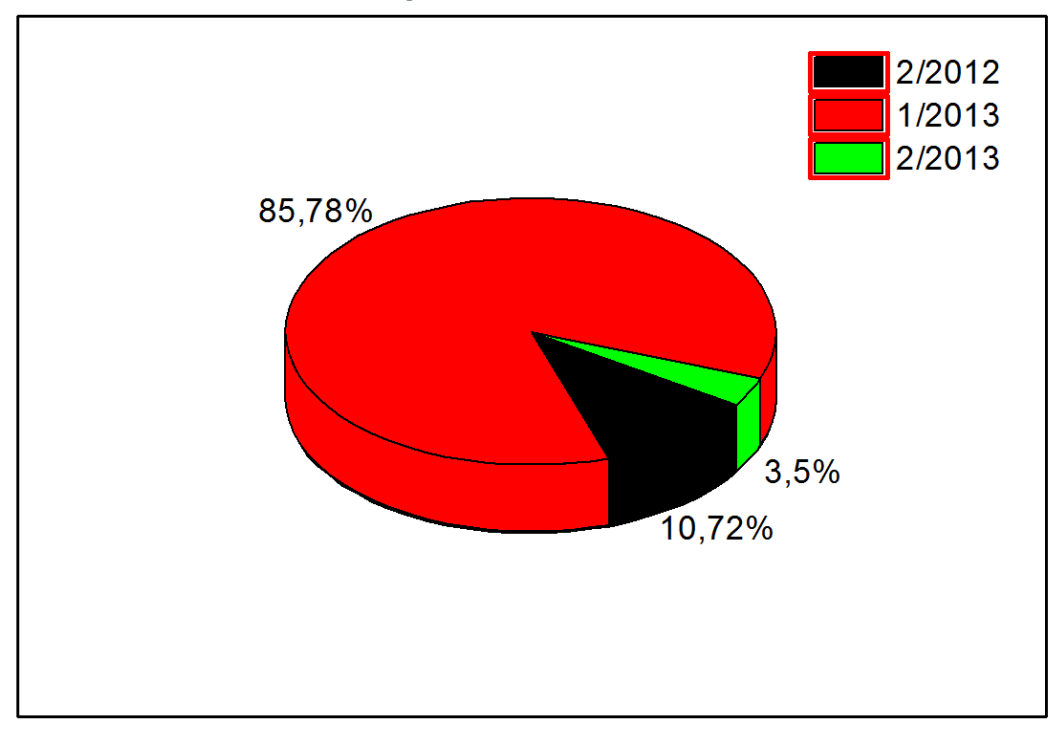

Figura 15 - Em qual semestre e ano o senhor ingressou no curso de licenciatura em Ciências Naturais? 
Foi visto disponibilidade dos alunos que participaram da pesquisa, no sentido de quererem contribuir para o trabalho com suas respostas. Muitos já entendiam o que era ser professor e estavam estudando a respeito. Houve maturidade no que concerne às respostas, mas dois alunos não mostraram tanto interesse ao responder ao questionário.

\section{Pergunta 2 - Vantagens do Jogo Perfil Astronômico.}

Nessa pergunta podia-se escolher quantas alternativas achasse necessário e eram vinte e três opções (de a até z). Cada alternativa foi analisada e foi observado em qual conteúdo se adequava dentre os conteúdos atitudinais, conceituais e procedimentais. Cada alternativa estava relacionada com um dos três conteúdos. As alternativas a, b, o, $\mathrm{i}, \mathrm{p}, \mathrm{v}, \mathrm{x}, \mathrm{g}$ se enquadravam no âmbito de conteúdos procedimentais, as alternativas c, d, q, e, r, s, t, u estavam relacionadas aos conteúdos atitudinais e as alternativas h, j, l, m, n estavam de acordo com os conteúdos conceituais. Nas figuras 16, 17 e 18 pode-se observar a porcentagem de escolhas relacionadas aos conteúdos. A seguir será mostrada a quantidade de escolhas para cada alternativa.

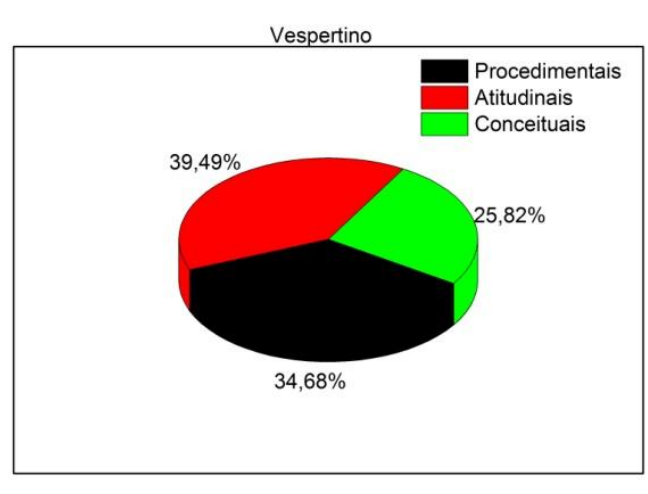

Figura 16 - Vantagens vespertino

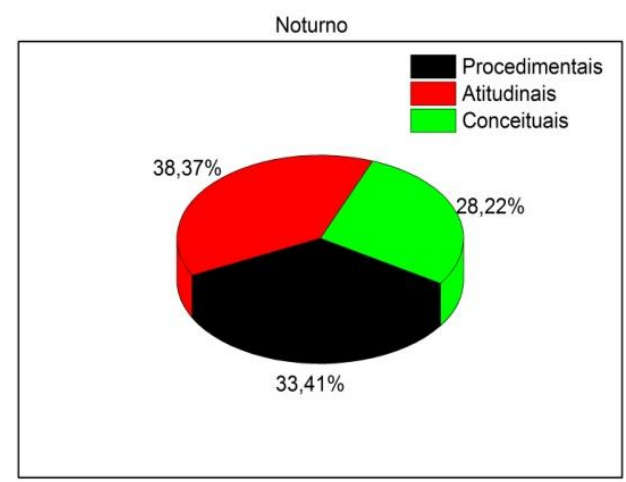

Figura 17 - Vantagens Noturno

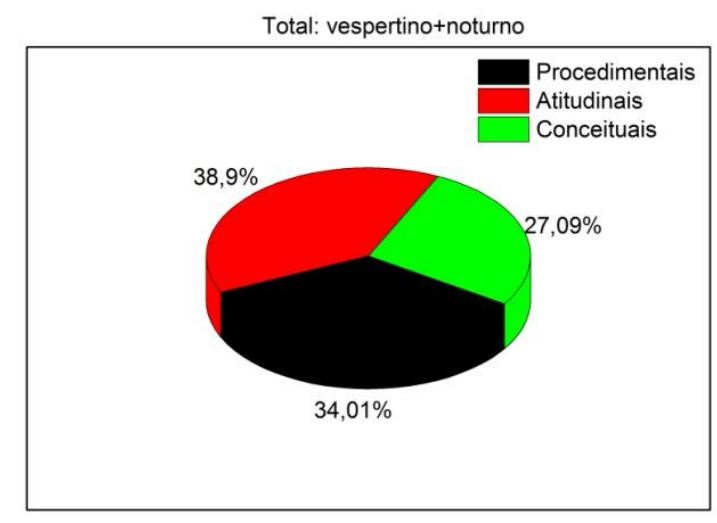

Figura 18 - Vantagens vespertino + noturno 
Das turmas pertencentes aos turnos diurno e noturno, somando cinquenta e quatro (54) alunos, totalizaram oitocentas e trinta e oito (838) respostas com relação às vantagens do Jogo, pois podiam escolher mais de uma alternativa.

Duzentas e oitenta e cinco (285) respostas condiziam com as alternativas com teor de conteúdo procedimental. Para ficar mais claro, foram feitas duas figuras dividindo as marcações de acordo com o turno diurno e o turno noturno (Figura 19 e 20). O propósito destas figuras é mostrar o equilíbrio das escolhas feitas pelos estudantes dos dois turnos. As alternativas com teor de conteúdo procedimental que foram escolhidas podem ser observadas a seguir.

a) favorece o raciocínio lógico;

b) possibilita construção de conhecimentos;

g) possibilita a fixação de conhecimento;

i) possibilita aprender sobre outros conteúdos;

o) faz lembrar conhecimentos já aprendidos;

p) possibilita a interação do que está sendo aprendido com conhecimentos já aprendidos;

v) desperta a curiosidade para que o aluno busque mais informações em outros lugares;

x) Possibilita a memorização.

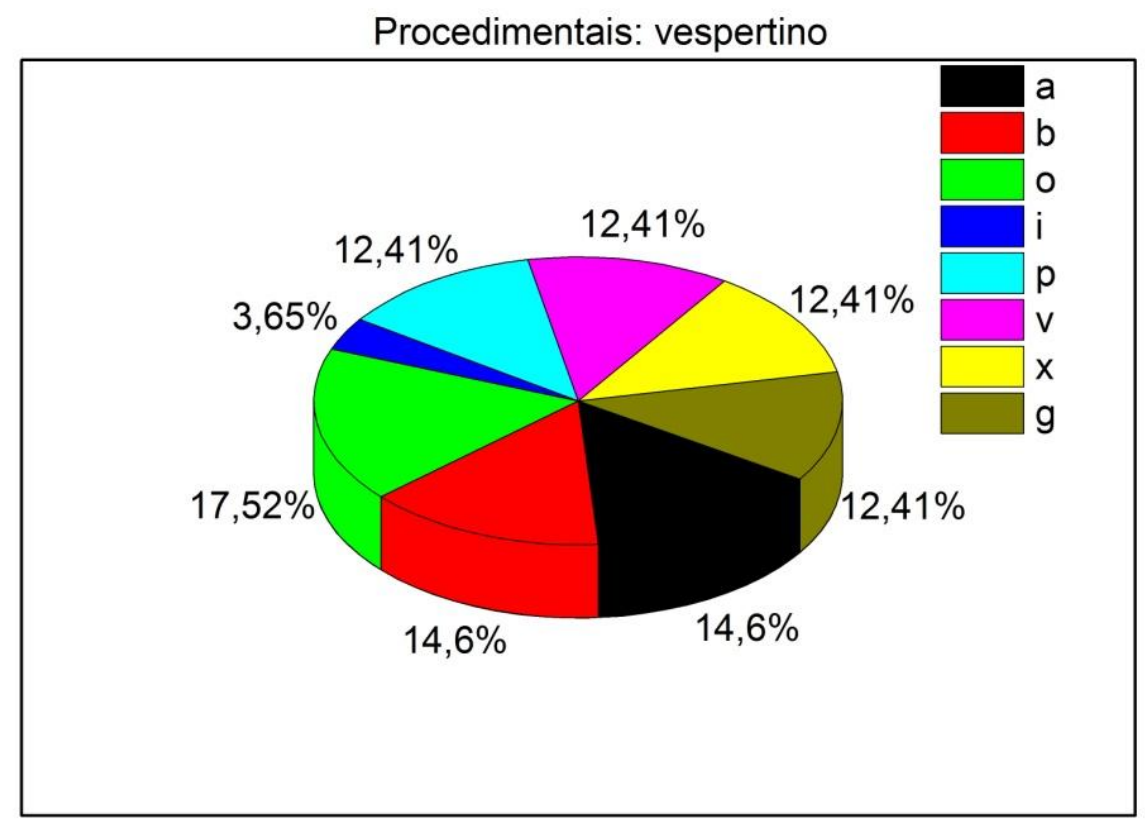

Figura 19 - Conteúdos Procedimentais - vespertino 


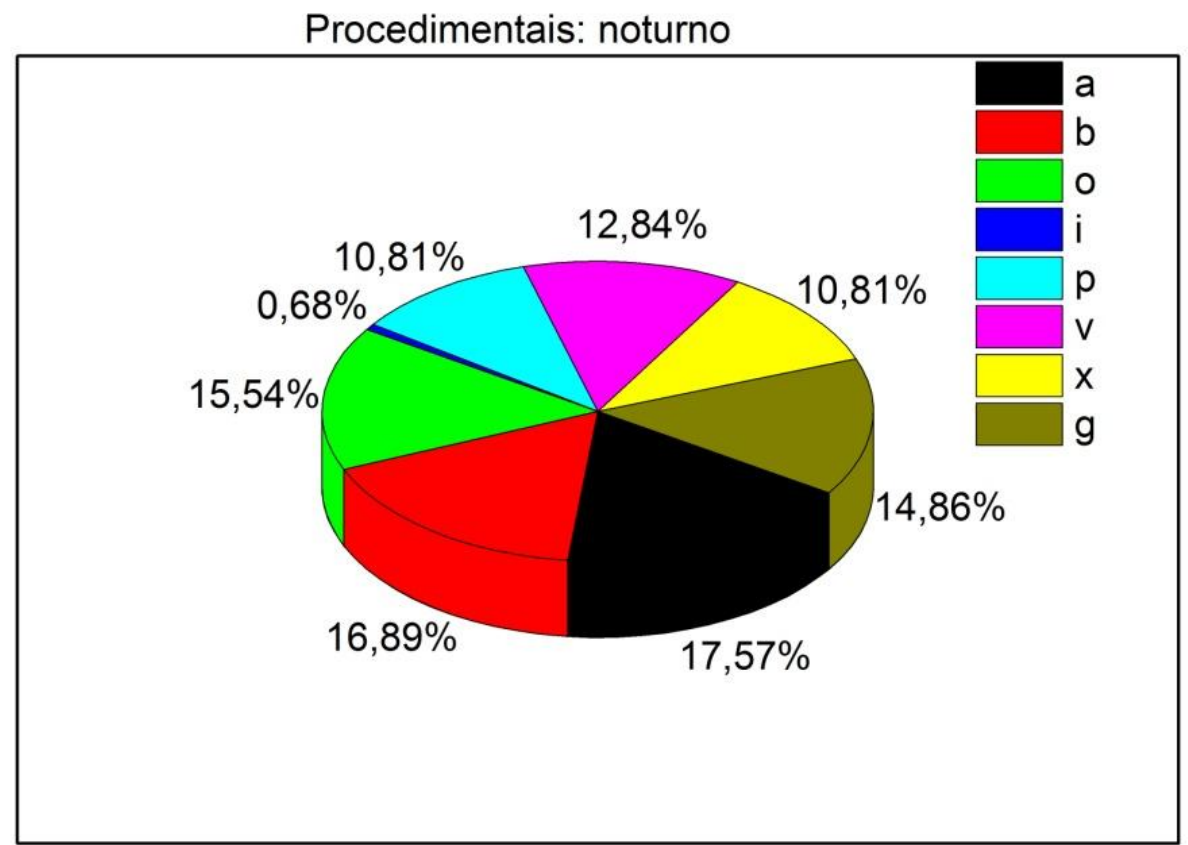

Figura 20 - Conteúdos Procedimentais - noturno

Já as alternativas que diziam respeito ao conteúdo atitudinal eram as seguintes:

c) gera interação;

d) gera competitividade;

e) possibilita a participação;

q) possibilita a interação entre os alunos;

r) possibilita a interação entre alunos e professor;

s) gera uma relação entre professor e aluno, sem espaço para inferioridade;

t) possibilita o compartilhamento dos conhecimentos dos alunos;

u) desperta a curiosidade.

Somando as duas turmas, o número de escolhas foi trezentos e vinte e seis (326) com relação às alternativas com este teor de conteúdo atitudinal. As marcações em alternativas que condiziam com conteúdo atitudinal estão mostradas na Figura 21 e na Figura 22. Para ficar mais claro, foram feitas duas figuras dividindo as marcações de acordo com o turno diurno e o turno noturno. O propósito das figuras é mostrar o equilíbrio das escolhas feitas pelos estudantes. 
Atitudinais: vespertino

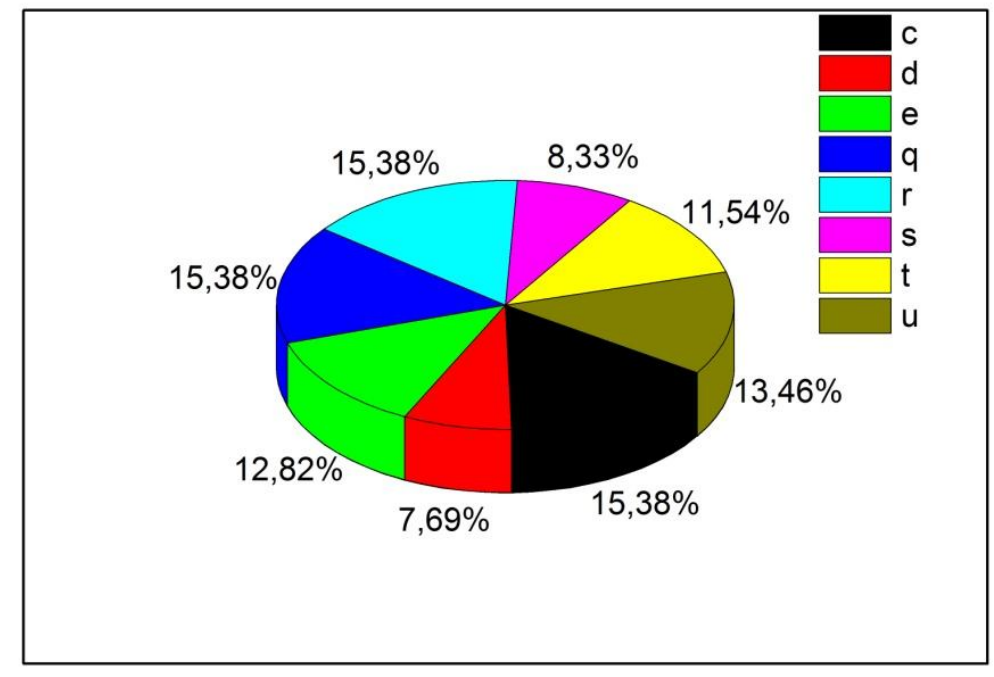

Figura 21 - Conteúdos Atitudinais - vespertino

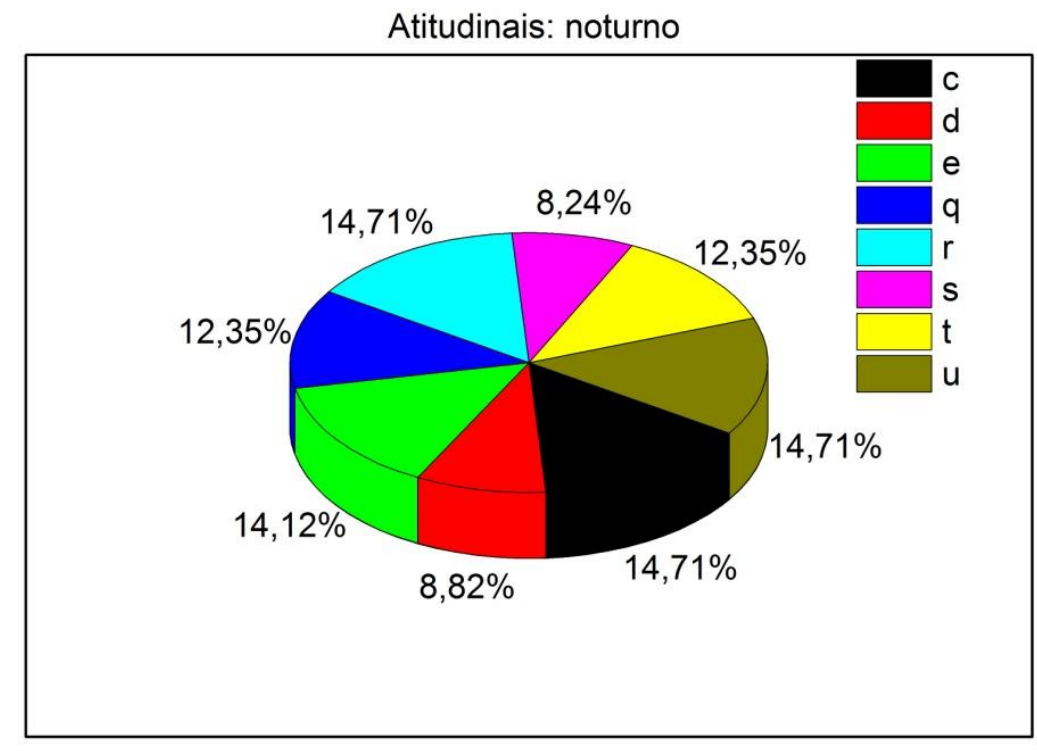

Figura 22 - Conteúdos Atitudinais - noturno

No que concerne às alternativas relacionadas aos conteúdos conceituais, as h, j, $1, \mathrm{~m}, \mathrm{n}$ estavam pertencentes a este grupo. Duzentas e vinte e sete (227) marcações foram relacionadas a estas questões conceituais, que aparecem em seguida. Para ficar mais claro o equilíbrio das escolhas feitas pelos estudantes, foram feitas duas figuras dividindo as marcações de acordo com o turno diurno e o turno noturno (Figura 23 e Figura 24). 
h) possibilita aprender sobre Astronomia;

j) possibilita aprender sobre corpos celestes;

1) possibilita aprender sobre cientistas;

m) possibilita aprender sobre instrumentos da Astronomia;

n) possibilita aprender sobre fenômenos e acontecimentos da Astronomia.

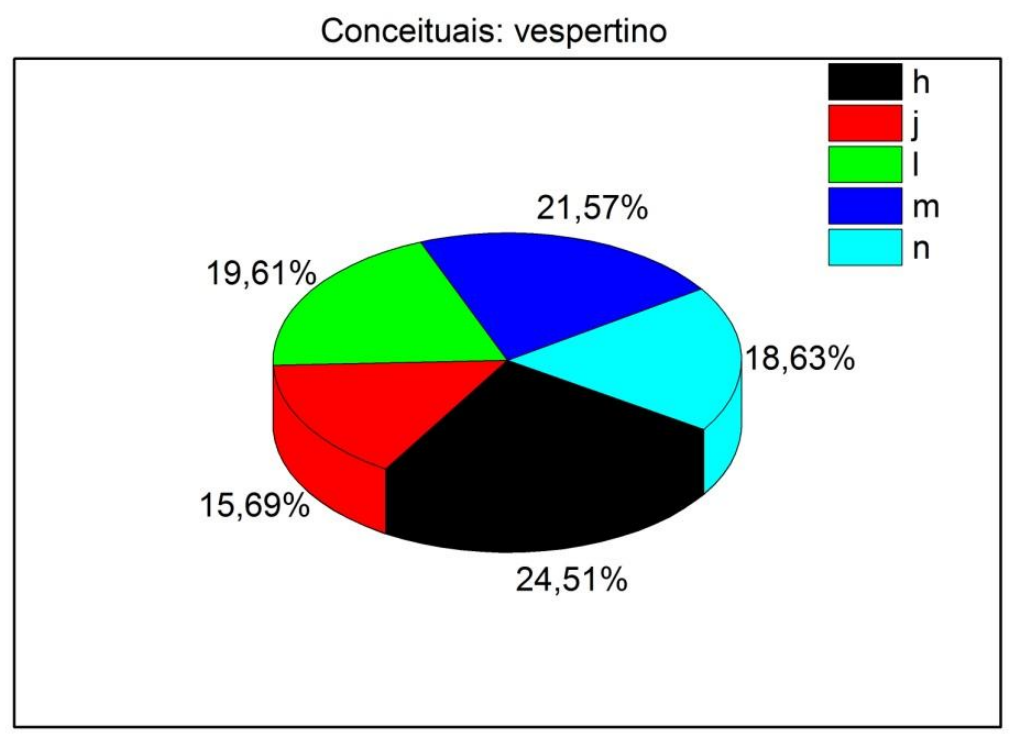

Figura 23 - Conteúdos Conceituais - vespertino

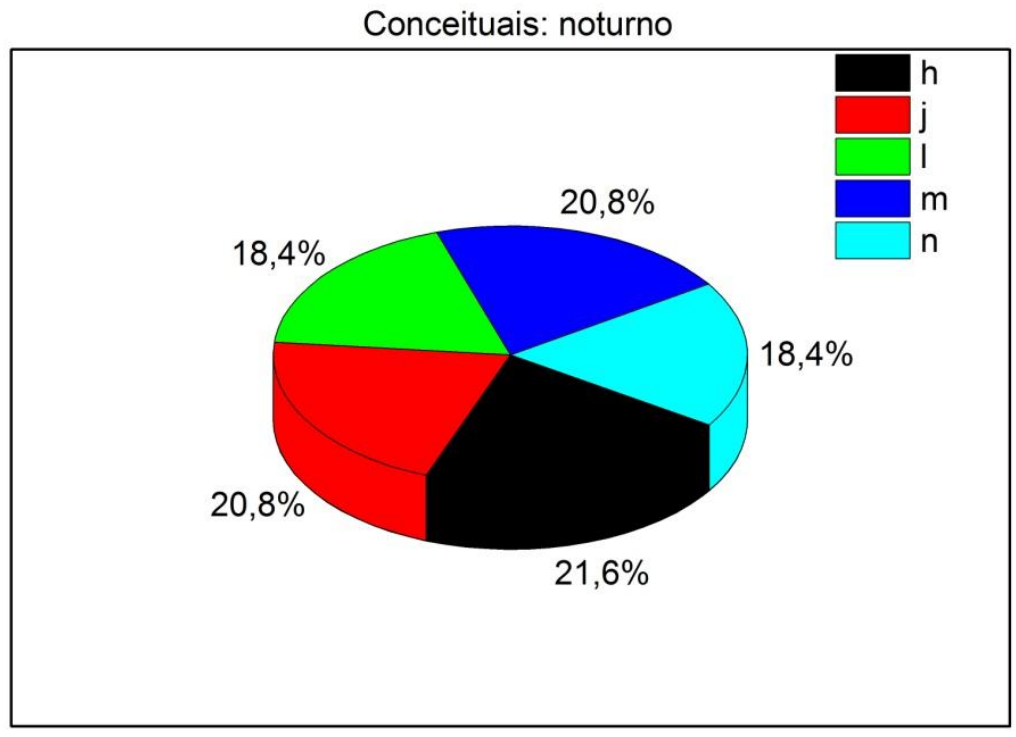

Figura 24 - Conteúdos Conceituais - noturno 
É possível notar que mesmo os alunos não sabendo que estavam sendo avaliados de acordo com os conteúdos atitudinais, conceituais e procedimentais, escolheram as alternativas de forma equilibrada, possibilitando perceber que o Jogo pode favorecer ao desenvolvimento dos três tipos de conteúdos.

Em uma análise específica, os alunos da turma do turno diurno que participaram do Jogo escolheram dentre vinte e três opções a respeito das vantagens do Jogo Perfil Astronômico. Eles podiam responder quantas alternativas achassem convenientes. O total de marcações foi de quatrocentos e oito (408). A alternativa mais escolhida foi a $\mathrm{h}$, com vinte e cinco (25) marcações, que diz que com o Jogo é possível aprender Astronomia. Logo em seguida, as alternativas c, o, q, $\mathrm{r}$ foram escolhidas vinte e quatro (24) vezes, e dizem, respectivamente, que o Jogo gera interação, faz lembrar conhecimentos já aprendidos, possibilita a interação entre os alunos, possibilita interação entre aluno e professor.

O número de escolhas das outras opções podem ser visualizadas na Figura 25. Dentre as vantagens do Jogo, havia as opções a serem escolhidas:

a) favorece o raciocínio lógico;

b) possibilita construção de conhecimentos;

c) gera interação;

d) gera competitividade;

e) possibilita a participação;

f) faz parecer que o tempo passa rápido;

g) possibilita a fixação de conhecimento;

h) possibilita aprender sobre Astronomia;

i) possibilita aprender sobre outros conteúdos específicos;

j) possibilita aprender sobre corpos celestes;

1) possibilita aprender sobre cientistas;

m) possibilita aprender sobre instrumentos da Astronomia;

n) possibilita aprender sobre fenômenos e acontecimentos da Astronomia;

o) faz lembrar conhecimentos já aprendidos;

p) Possibilita a interação do que está sendo aprendido com conhecimentos já aprendidos;

q) possibilita a interação entre os alunos;

r) possibilita a interação entre alunos e professor;

s) gera uma relação entre o professor e aluno, sem espaço para inferioridade; 
t) possibilita o compartilhamento dos conhecimentos dos alunos;

u) desperta a curiosidade;

v) desperta a curiosidade para que o aluno busque mais informações em outros

lugares;

x) possibilita a memorização;

z) outros (especificar).

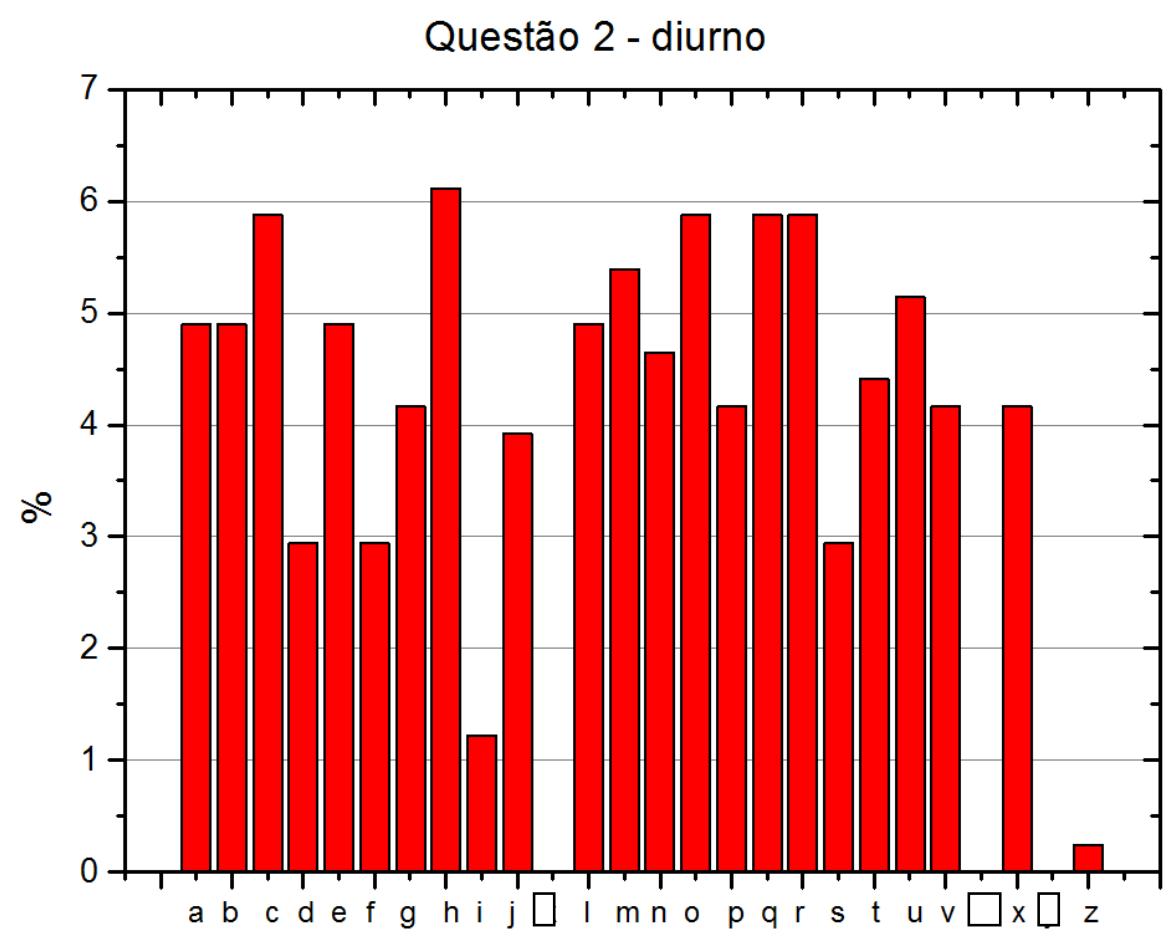

Figura 25 - Vantagens do Jogo Perfil Astronômico

Continuando a análise específica, na turma do período noturno havia vinte e oito (28) alunos participantes do Jogo, e também havia vinte e três opções a respeito das vantagens do Jogo Perfil Astronômico. Os alunos podiam responder quantas alternativas achassem convenientes. O total de marcações foi quatrocentos e sessenta e uma (461). A alternativa mais escolhida foi a h (assim como a primeira opção da turma do período diurno), com vinte e sete marcações (27), e diz que com o Jogo é possível aprender Astronomia. Logo em seguida, as alternativas a, j, m foram escolhidas vinte e seis (26) vezes, cada uma, e dizem, respectivamente, que o Jogo Perfil astronômico favorece o raciocínio lógico, possibilita aprender sobre corpos celestes, e possibilita aprender sobre instrumentos de Astronomia. As opções b, c, r, u foram escolhidas vinte e cinco vezes 
(25), cada uma, e dizem, respectivamente, que o Jogo Perfil astronômico possibilita a construção de conhecimentos, gera interação, possibilita a interação entre alunos e professor, desperta a curiosidade. As porcentagens com relação às outras opções escolhidas podem ser visualizadas na Figura 26. O mesmo questionário foi aplicado nas turmas do turno diurno e noturno, então dentre as vantagens do Jogo, havia as mesmas opções a serem escolhidas:

a) favorece o raciocínio lógico;

b) possibilita construção de conhecimentos;

c) gera interação;

d) gera competitividade;

e) possibilita a participação;

f) faz parecer que o tempo passa rápido;

g) possibilita a fixação de conhecimento;

h) possibilita aprender sobre Astronomia;

i) possibilita aprender sobre outros conteúdos;

j) possibilita aprender sobre corpos celestes;

1) possibilita aprender sobre cientistas;

m) possibilita aprender sobre instrumentos da Astronomia;

n) possibilita aprender sobre fenômenos e acontecimentos da Astronomia;

o) faz lembrar conhecimentos já aprendidos;

p) possibilita a interação do que está sendo aprendido com conhecimentos já aprendidos;

q) possibilita a interação entre os alunos;

r) possibilita a interação entre alunos e professor;

s) gera uma relação entre o professor e aluno, sem espaço para inferioridade;

t) possibilita o compartilhamento dos conhecimentos dos alunos;

u) desperta a curiosidade;

v) desperta a curiosidade para que o aluno busque mais informações em outros lugares;

x) possibilita a memorização;

z) outros (especificar). 


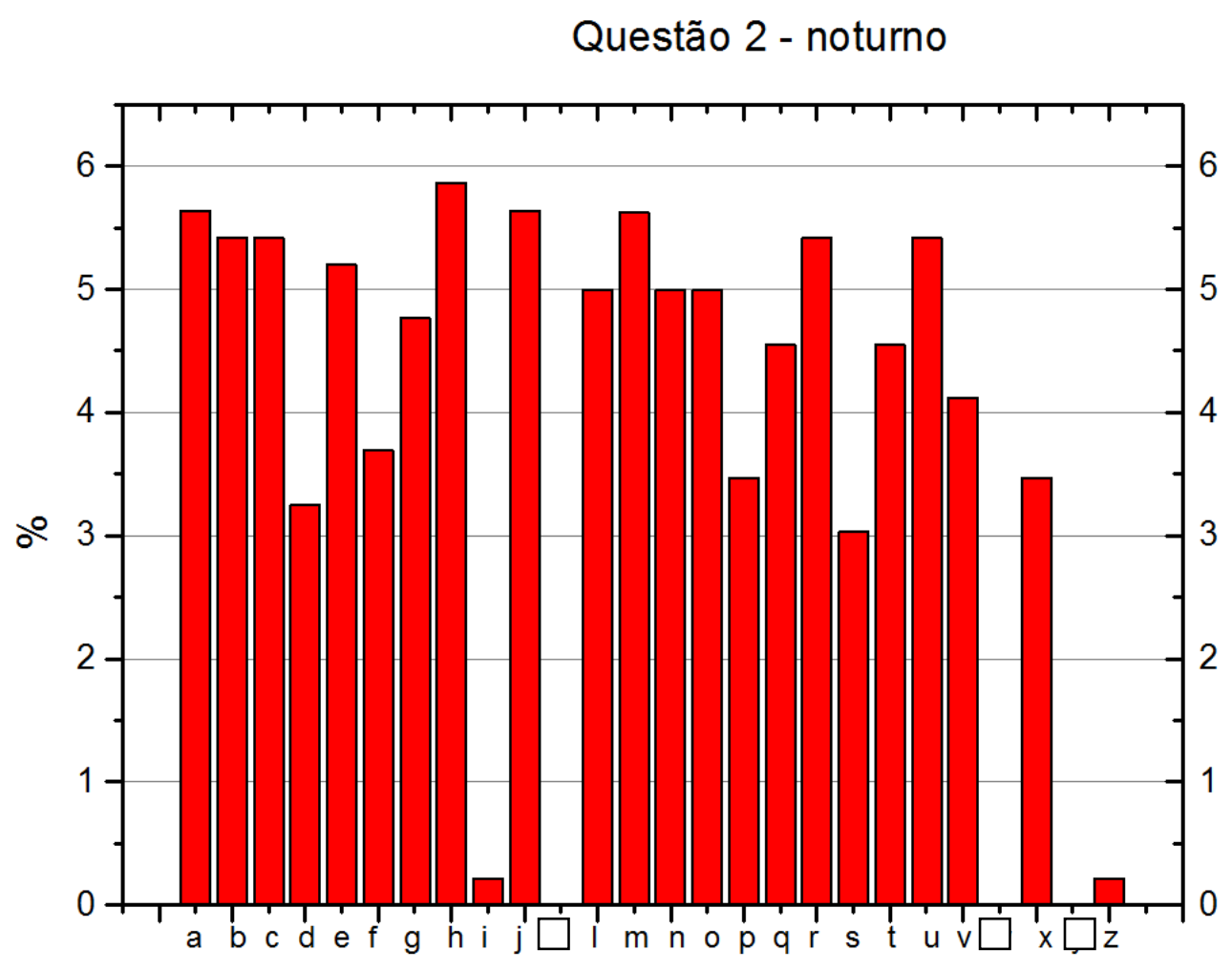

Figura 26 - Vantagens do Jogo Perfil Astronômico

Pergunta 3 - Desvantagens do Jogo Perfil Astronômico.

Esta questão tinha o propósito de saber o que o Jogo não conseguia transmitir na hora da aplicação ou o que desenvolvia no jogador de forma negativa, ou ainda, nos dar retorno do que poderia ser melhorado. Também podia-se escolher quantas alternativas achasse necessário. Estas alternativas também foram analisadas de um ponto de vista dos conteúdos conceituais, atitudinais e procedimentais. Foram trinta e seis (36) marcações somando as respostas dos dois turnos. Dentre as respostas do turno noturno e diurno:

- Dez (10) marcações foram feitas para desvantagens que estavam centradas nos conteúdos procedimentais: $\mathrm{b}, \mathrm{o}, \mathrm{i}, \mathrm{v}, \mathrm{g}$;

- Dezessete (17) marcações foram feitas nas alternativas c, d, e, r, u, relacionadas aos conteúdos atitudinais;

- Nove (09) escolhas foram realizadas nas alternativas h, 1, m, para as desvantagens relacionadas aos conteúdos conceituais. 
Em separado, na turma do período diurno, totalizaram-se dezessete (17) marcações, em que eram escolhidas as alternativas referentes às desvantagens do jogo. Seis (06) opções foram marcadas na opção d, que diz que o Jogo gera competitividade exagerada. Depois, com apenas duas (02) marcações, as opções g, h, m foram escolhidas, e nelas estão dizendo que o Jogo não possibilita a fixação de conhecimento, apenas faz memorizar os conceitos do jogo, não possibilita aprender sobre instrumentos da Astronomia. Observe as porcentagens das respostas pela Figura 27. As opções eram as seguintes:

a) não favorece o raciocínio lógico;

b) não possibilita construção de conhecimentos;

c) não gera interação.

d) gera competitividade exagerada;

e) não possibilita a participação;

f) não é possível aprender;

g) não possibilita a fixação de conhecimento;

h) apenas faz memorizar os conceitos do jogo;

i) não possibilita a interação de conceitos;

j) não possibilita aprender sobre corpos celestes;

1) não possibilita aprender sobre cientistas;

m) não possibilita aprender sobre instrumentos da Astronomia;

n) não possibilita aprender sobre fenômenos e acontecimentos da Astronomia;

o) não há espaço para demonstrar o que já sabe;

p) não possibilita a interação do que está sendo aprendido com conhecimentos já aprendidos;

q) não possibilita a interação entre os alunos;

r) não possibilita a interação entre alunos e professor;

s) não é divertido;

t) não possibilita o compartilhamento dos conhecimentos dos alunos;

u) não desperta a curiosidade;

v) não desperta a curiosidade para que o aluno busque mais informações em outros lugares;

x) não é dinâmico;

z) outros (especificar). 


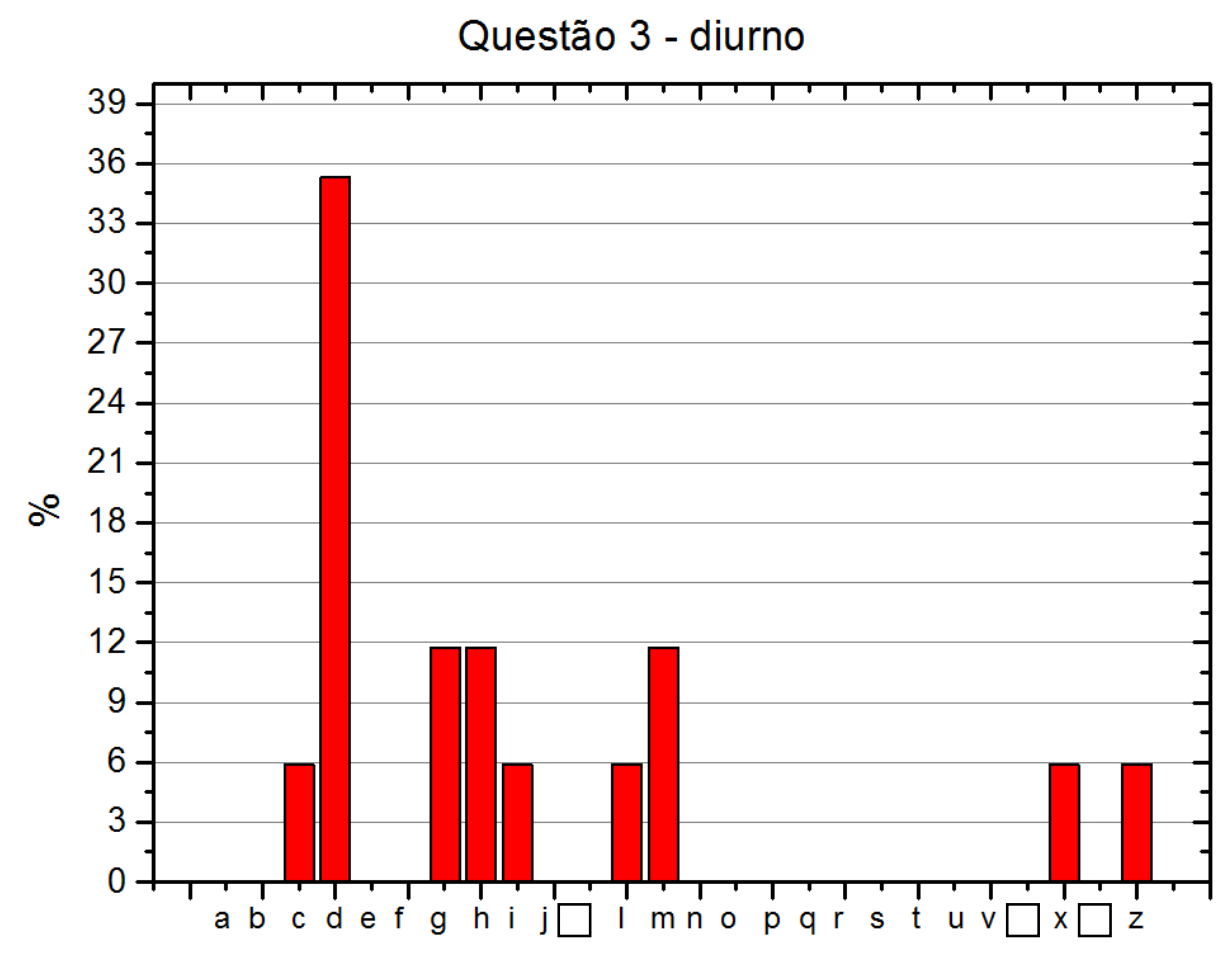

Figura 27 - Desvantagens do Jogo Perfil Astronômico

Os alunos do período noturno também podiam escolher diversas alternativas, e totalizaram dezenove (19) marcações, em que eram escolhidas as alternativas referentes às desvantagens do jogo. Quatro (04) opções foram marcadas na opção c, que diz que o Jogo não gera interação. Depois, as opções g e n foram escolhidas, e nelas estão dizendo que o Jogo não possibilita a fixação de conhecimento e não possibilita aprender sobre fenômenos e acontecimentos da Astronomia. As outras opções escolhidas podem ser observadas na Figura 28. As opções eram as seguintes:

a) não favorece o raciocínio lógico;

b) não possibilita construção de conhecimentos;

c) não gera interação;

d) gera competitividade exagerada;

e) não possibilita a participação;

f) não é possível aprender;

g) não possibilita a fixação de conhecimento;

h) apenas faz memorizar os conceitos do jogo;

i) não possibilita a interação de conceitos;

j) não possibilita aprender sobre corpos celestes; 
1) não possibilita aprender sobre cientistas;

m) não possibilita aprender sobre instrumentos da Astronomia;

n) não possibilita aprender sobre fenômenos e acontecimentos da Astronomia;

o) não há espaço para demonstrar o que já sabe;

p) não possibilita a interação do que está sendo aprendido com conhecimentos já aprendidos;

q) não possibilita a interação entre os alunos;

r) não possibilita a interação entre alunos e professor;

s) não é divertido;

t) não possibilita o compartilhamento dos conhecimentos dos alunos;

u) não desperta a curiosidade;

v) não desperta a curiosidade para que o aluno busque mais informações em outros lugares;

x) não é dinâmico;

z) outros (especificar).

Questão 3 - noturno

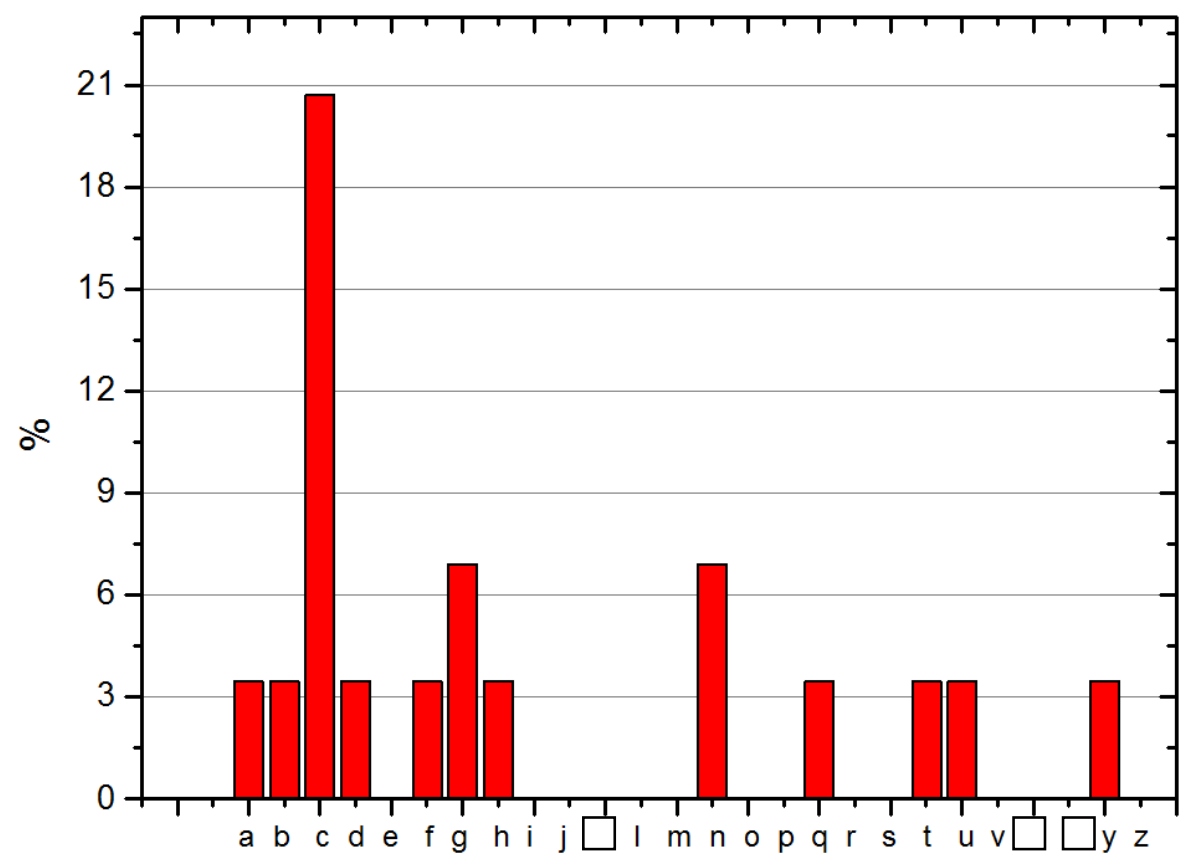

Figura 28 - Desvantagens do Jogo Perfil Astronômico 
Foi importante notar essas respostas para que se observasse os benefícios do Jogo e as desvantagens também dentro de um contexto dos conteúdos atitudinais, procedimentais e conceituais.

Pergunta 4 - Você aprendeu com o Jogo Perfil Astronômico?

Essa pergunta tinha o objetivo de entender se o aluno era capaz para perceber um novo aprendizado, e, na questão, tinha espaço para responder o que aprendeu e como aprendeu. Queríamos ver se os estudantes percebiam o Jogo como um instrumento de aprendizagem mais do que como um recurso de entretenimento e interação. Foi importante perceber que eles consideravam possível aprender com o Jogo e ver a capacidade do aluno de se autoavaliar e avaliar o próprio Jogo, sendo um futuro professor.

Vinte e três (23) participantes de um total de vinte e seis (26), da turma do turno diurno, aproximadamente $89 \%$ (pode ser visto na Figura 29), responderam que aprenderam com o Jogo Perfil Astronômico. Eles puseram o que foi aprendido e dentre as respostas estão:

- "Neste Jogo, aprendi praticamente de tudo".

• "Jogando, aprendi muito, pois não sabia sobre Astronomia".

- "Este Jogo é mais do que fixação de conceitos e se constrói os conceitos".

- As outras respostas indicam que aprenderam sobre conceitos de Astronomia, corpos celestes, as luas de Júpiter, satélites de planetas, locais e suas características, tamanho dos planetas, diâmetro dos corpos celestes, cientistas, teoria heliocêntrica e Copérnico, estrelas e seus estágios, anãs-brancas, instrumentos e objetos da Astronomia, sobre a história, o tempo e o que aconteceu nele.

- Disseram que perceberam que são conhecimentos do dia-a-dia, como os planetas e instrumentos da Astronomia, e também que alguns instrumentos podem ser construídos com materiais do dia-a-dia como com canos e CDs velhos.

Vale lembrar que atitudes foram percebidas quando escreveram que o Jogo os fez querer buscar conhecimento fora da aula e que desperta a vontade de aprender. Outros escreveram que lembraram o que já tinham esquecido com o auxílio das dicas. 
Em relação a forma com que aprenderam com o Jogo, disseram que as dicas foram essenciais e que a repetição delas auxiliava, assim como a análise das respostas dos outros. Ouvindo opiniões e dialogando, interagindo, observando o raciocínio dos colegas e com o conhecimento dos outros foi possível aprender, segundo eles. Disseram, também, que pela dinâmica do Jogo e de forma lúdica, aprenderam.

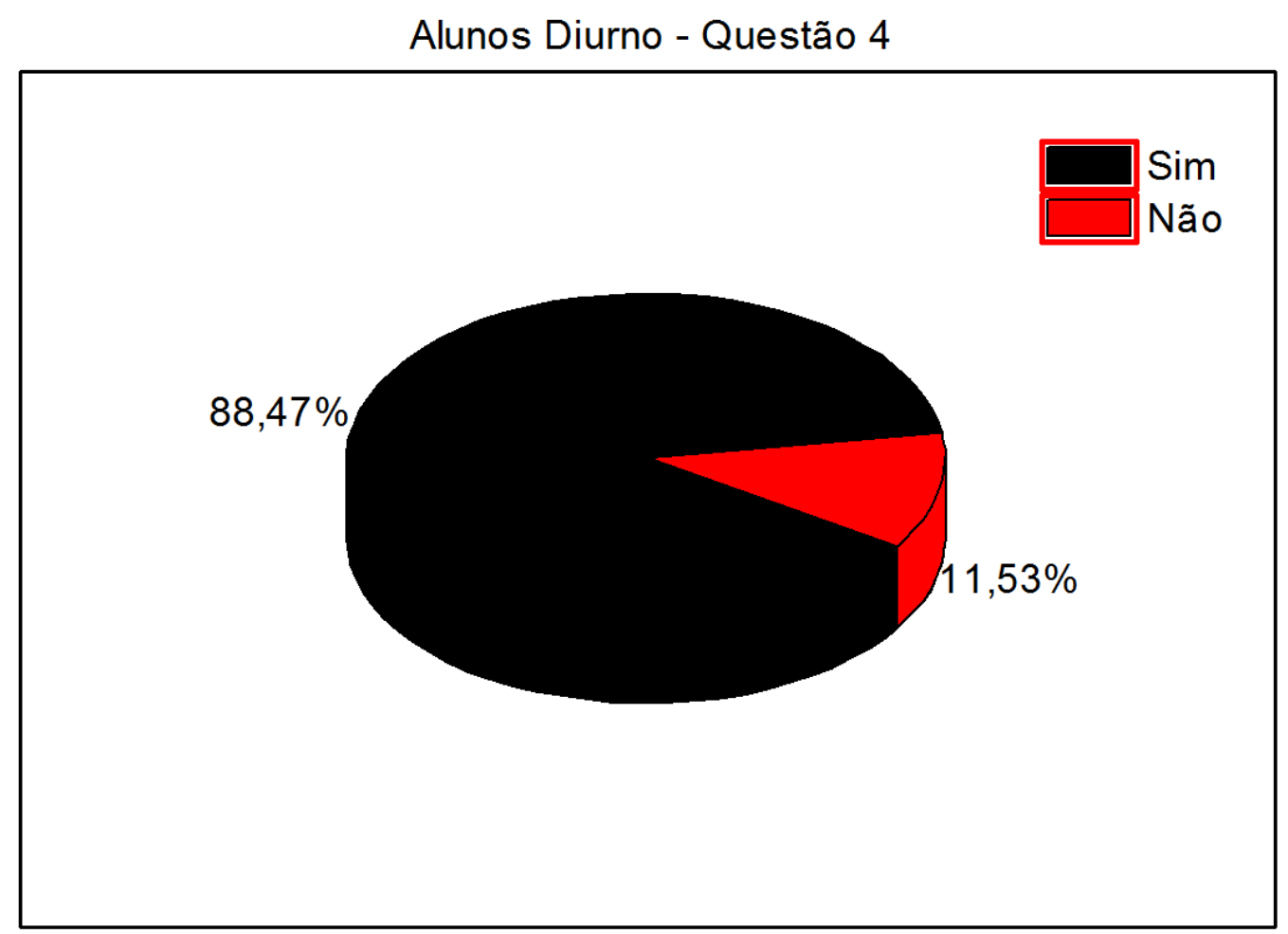

Figura 29 - Aprenderam com o Jogo Perfil Astronômico?

Vinte e oito (28) participantes, que corresponde a 100\% do grupo da turma do turno noturno, responderam que aprenderam com o Jogo Perfil Astronômico. Eles puseram o que foi aprendido e dentre as afirmações, um dos alunos afirma que depois de ter participado do Jogo viu que deve estudar mais, buscar informações fora de sala e comparar com o que viu no Jogo. A seguir, estão falas e escritas de estudantes:

- "Aprendi a buscar mais informações fora também para não ficar com dúvidas".

- "Com este Jogo há possibilidade de apreensão com pouco recurso".

- "Relembrei outros assuntos e aprendi sobre Astronomia".

- "Aprendi curiosidades do Universo que não tinha visto na sala de aula".

- "Com este Jogo dinâmico, criativo, se desperta interesse e curiosidade". 
- "Vou estudar mais a respeito".

- "Este Jogo desperta desejo de aprender".

- "Pelas dicas, se estimula o raciocínio e o que já sabemos".

- "Aprendi mais e descobri".

• "O Universo é vasto, e eu não sabia".

- "O raciocínio e a troca de conhecimento pode ajudar o aluno".

- "Aprendi sobre planeta e seus funcionamentos, e que instrumentos e sistema planetário são significativos".

- "Inserindo o que sei, o já existente, aprendi".

- "Este Jogo coopera para a aprendizagem".

As outras respostas, colocadas nesta questão, indicam que aprenderam sobre Astronomia e seus conceitos, conceitos básicos da Astronomia, corpos celestes, planetas, instrumentos, bússola e como ela gira na posição vertical, vários locais, satélites, luas, cientistas, nomes de pesquisadores, historiadores. Há conteúdos atitudinais quando, em relação à forma com que aprenderam com o Jogo, disseram que as perguntas e dicas foram de suma importância para a aprendizagem e para ter atitude de pesquisar a respeito de temas de astronomia. Segundo eles, a interação e dinâmica e o conhecimento compartilhado entre colegas auxiliou para que ocorresse o aprendizado. Há conteúdos procedimentais quando eles disseram que, ao ouvir as características e dicas, descobriram o que era o elemento da carta e foram estimulados a buscar o conhecimento de variadas formas. Compartilhando o conhecimento entre os colegas, ouvindo as respostas dos outros, observando o Jogo e sua dinâmica, participando e interagindo, dialogando, lembrando o que já se sabe e debatendo entre os grupos foi possível compreender novos conceitos, de acordo com eles. Conteúdos atitudinais e conteúdos procedimentais foram relacionados nessas formas de proceder que os alunos expressaram.

Pergunta 5 - Que restrição, em termos de material ou características do Jogo, você faria?

Nessa questão percebemos a criticidade do estudante participante e vimos as contribuições para a melhoria do Jogo. 
$\mathrm{Na}$ turma do turno diurno, a pergunta $\mathrm{n}^{\circ} 5$ não pontuou nenhuma resposta afirmativa. Na turma do turno noturno, disseram que seria bom dividir as cartas de acordo com o nível de conhecimento, mas isso já acontece. Também disseram para colorir as cartas.

Pergunta 6 - O que você acha que pode ser melhorado no Jogo?

O propósito da pergunta era perceber e utilizar da contribuição do estudante para o Jogo.

Alunos da turma do turno diurno afirmaram que poderia ter um tempo definido para cada grupo responder. Isto depende do aplicador do Jogo. Como animais que foram importantes na história da Astronomia, como a cachorra Laika, estavam na categoria de Instrumentos das cartas, alunos escreveram que tirar a classe animal desta parte seria bom.

Na turma do turno noturno, afirmaram que poderiam dar tempo para estudar, antes de o Jogo começar. Outro comentário escrito, de um dos alunos, é que seria pertinente fazer um tabuleiro maior em que os alunos andassem por cima.

Pergunta 7 - Depois de formado em licenciatura em Ciências Naturais, você experimentaria aplicar jogos ao longo das suas aulas? Por quê?

Essa pergunta foi feita para observarmos se a partir da aplicação do Perfil Astronômico ele podia mudar sua ideia sobre jogos, e mesmo para saber se o estudante já está sendo formado com a visão de que usar jogos pode fazer parte de uma metodologia de aula.

Todos os participantes da turma do turno diurno responderam que sim. E explicaram que jogo traz mais dinamismo na aula, mais interesse dos alunos pela matéria e pela aula; fica divertido ensinar, é um teste de conhecimento e fixação, faz buscar mais conhecimentos fora da sala, é um bom instrumento de ensino, gera participação e conhecimento, gera interesse em aprofundar o conhecimento, que é um meio ótimo para que aconteça interação entre aluno e entre professor e aluno, motiva o aprendizado, facilita o aprendizado, diverte e ajuda para melhorar o raciocínio, porque ensina de forma lúdica. Alguns entenderam que, na pergunta, podia-se responder sobre 
a aplicação do Jogo Perfil Astronômico e disseram sobre esse assunto. Estas afirmações aparecem nas respostas apresentadas a seguir.

$\mathrm{Na}$ turma do turno noturno explicaram que jogo traz mais conhecimento e melhora o aprendizado no que diz respeito ao aluno. Segundo as respostas, com o jogo os alunos participam, formulam novas ideias, é mais divertido para aprender, e as aulas ficam interativas e facilita a aprendizagem. Eles dizem que o jogo traz uma forma da turma interagir e aprender. Afirmam que o Jogo Perfil astronômico favorece mais a construção de ideias do que a memorização.

A seguir, estão frases que evidenciam o que foi explanado pelos estudantes participantes:

- “A vida é um jogo e se aprende bastante com este jogo contínuo. O Jogo Perfil é importante para aprendermos".

• "Jogo é a melhor opção".

- "Diverte, aprende brincando".

- "Jogo é a melhor maneira de ensinar e fixar o conteúdo".

- "Jogo Perfil astronômico favorece mais a construção de ideias do que a memorização".

- Disseram também que jogo é dinâmico e interativo, lúdico, motiva o interesse, pode ser uma forma de revisão, tem didática interessante, causa interação e transferência de conhecimento."

- De acordo com eles, o jogo gera dinâmica e debate de conhecimento aprendido e aumenta a concentração dos alunos.

Nessas últimas falas é visível a predominância de conteúdos conceituais, embora eles tenham identificado equilibradamente os conteúdos atitudinais e procedimentais nas respostas das perguntas quatro, cinco e seis. Houve a expressão dos três tipos de conteúdos - atitudinais, procedimentais e conceituais - com atitudes, lembrança de conhecimentos já aprendidos e incorporados, novos comportamentos e comprometimento em pesquisar informações, em ver e perceber diariamente o que foi aprendido. 
Pergunta 8 - Você considera importante que os estudantes do ensino fundamental e médio aprendam a respeito do tema Astronomia? Por quê?

Com esta pergunta foi possível perceber muitas exposições a respeito da importância da Astronomia e que, na aplicação do Jogo, eles mudaram de ideia, expressas nas frases:

- “Agora vi que a Astronomia faz parte da história do mundo e é importante ensinar isto".

- “Astronomia está no nosso dia".

- "É importante que um aluno conheça tudo desta ciência".

- "Estudar Astronomia faz conhecer o mundo".

- "Vou ensinar estes conteúdos no ensino fundamental".

O objetivo desta pergunta era este: entender se o aluno compreendia a Astronomia como importante ciência para se ensinar em sala de aula.

Um estudante da turma do turno diurno não respondeu a esta pergunta, mas os outros vinte e cinco (25) alunos disseram que sim. Dentre as explicações disseram que pela Astronomia se compreende a origem de tudo, aprende-se sobre o universo, que são conhecimentos do dia-a-dia, que gera interesse, é uma matéria curiosa, desperta vontade de aprender, por ela se entende o meio em que se vive e esse conhecimento pode ser usado ao longo da vida, e é um tema importante e não dão prioridade. Responderam, também, que se tiver esta dinâmica, este Jogo, será uma motivação para estudar.

Em relação à turma do turno noturno, um participante não respondeu a esta pergunta, mas os outros vinte e sete (27) alunos colocaram resposta afirmativa. Dentre as explicações, afirmaram que o tema desperta curiosidade, é uma das bases científicas, pode formar futuros cientistas, a matéria não é chata, faz relação com a geografia, física (no ensino fundamental e médio), faz entender sobre Universo e relacionar com o dia-a-dia. Eles entendem que é um tema bom para todas as idades, e relatam que a Astronomia é importante e é um tema curioso, pode-se descobrir novos conteúdos a partir dela e se aprofundar na área. Algumas afirmações que apareceram como resposta à pergunta: 
- "Astronomia possibilita a compreensão do espaço em que se vive".

- "Todos têm que saber da influência do universo, hoje".

- "O tema é importante porque o universo é a nossa casa".

- "A Astronomia ajuda a alguém perdido a se encontrar".

- "Deve-se aprender Astronomia para não passar dificuldades na faculdade".

- "A Astronomia estimula o amor pela física astronômica".

- "A Astronomia é uma disciplina científica e possibilita entender a física".

\subsection{Análise dos Registros de aula}

As anotações no caderno de campo e as gravações das aulas nos permitiram analisar as falas dos alunos durante o Jogo, uma vez que a aplicação foi feita por outro professor e a pesquisadora ficou registrando a movimentação da sala de aula.

Foi percebido o desenvolvimento de conteúdos atitudinais, que os alunos demonstraram em relação à aprendizagem. Essas atitudes foram percebidas com o auxílio de parte da tabela 2 (tabela 3) que mostra a diferença entre discurso científico de outros discursos, forma de fazer perguntas, cooperação, enfoque superficial (repetitivo), enfoque profundo (busca de significado) como parte de conteúdos atitudinais, dentre outros aspectos que podem ser observados a seguir.

Tabela 3 - Conteúdos atitudinais

\begin{tabular}{|c|c|}
\hline \multirow{6}{*}{ Em relação à Ciência } & Discurso científico de outros discursos \\
\hline & Atitude reflexiva e crítica \\
\hline & Visão relativista e histórica \\
\hline & Forma de fazer perguntas \\
\hline & $\begin{array}{c}\text { Diferenciar a abordagem científica de outras } \\
\text { abordagens }\end{array}$ \\
\hline & Gosto pelo rigor e precisão no trabalho \\
\hline \multirow{2}{*}{$\begin{array}{l}\text { Em relação ao papel social } \\
\text { da ciência }\end{array}$} & Cooperação \\
\hline & $\begin{array}{l}\text { Discussão crítica da aplicação da ciência na } \\
\text { sociedade }\end{array}$ \\
\hline \multirow{2}{*}{$\begin{array}{l}\text { Em relação à aprendizagem } \\
\text { da ciência }\end{array}$} & Enfoque superficial (repetitivo) \\
\hline & Enfoque profundo (busca de significado) \\
\hline
\end{tabular}

$\mathrm{Na}$ análise do material que foi escrito também aparece o desenvolvimento de conteúdos atitudinais. Um aluno disse que iria pesquisar mais a respeito de uma carta 
jogada, pois tinha gostado de saber de novas informações. Outros disseram que na hora do Jogo foi possível relacionar com informações que já tinham lido em materiais impressos e na internet, e assistido em programas de televisão.

Muita concentração, devido ao olhar fixo ao professor, e também agitação, que foi vista na empolgação, gritarias e risadas dos alunos, foram demonstradas nas aplicações do jogo, e o trabalho cooperativo dos grupos foi visto quando se ajudavam a lembrar de dados das cartas do Jogo ou mesmo de conhecimentos já sabidos. Todo o tempo eles quiseram dividir as informações entre os grupos para chegar a uma conclusão da resposta da carta, anotar as informações das cartas, mexer na internet para buscar dados e relacioná-los às cartas. Estas ações fazem parte dos conteúdos atitudinais.

Para enfatizar, nos registros, constatamos o desenvolvimento de conteúdos atitudinais como a concentração demonstrada no olhar fixo ao professor. A empolgação foi vista na agitação e falas altas. Uma atitude reflexiva e crítica foi observada quando o professor dizia uma informação do jogo, e eles pensavam, perguntavam se estava certo mesmo, indagavam entre si. Mais duas atitudes foram observadas neste momento, como a cooperação e forma de fazer perguntas. O grupo sempre auxiliava ao outro, mostrando uma informação que escrevera ou que buscara no celular. Estudantes disseram que aprenderam na hora do jogo e entenderam novos conceitos.

As Figuras 30, 31 e 32 mostram a interação de um grupo e a busca de informações em diferentes recursos. As duas últimas Figuras (31 e 32) mostram expressões de conteúdos atitudinais e, ao mesmo tempo, de conteúdos procedimentais.

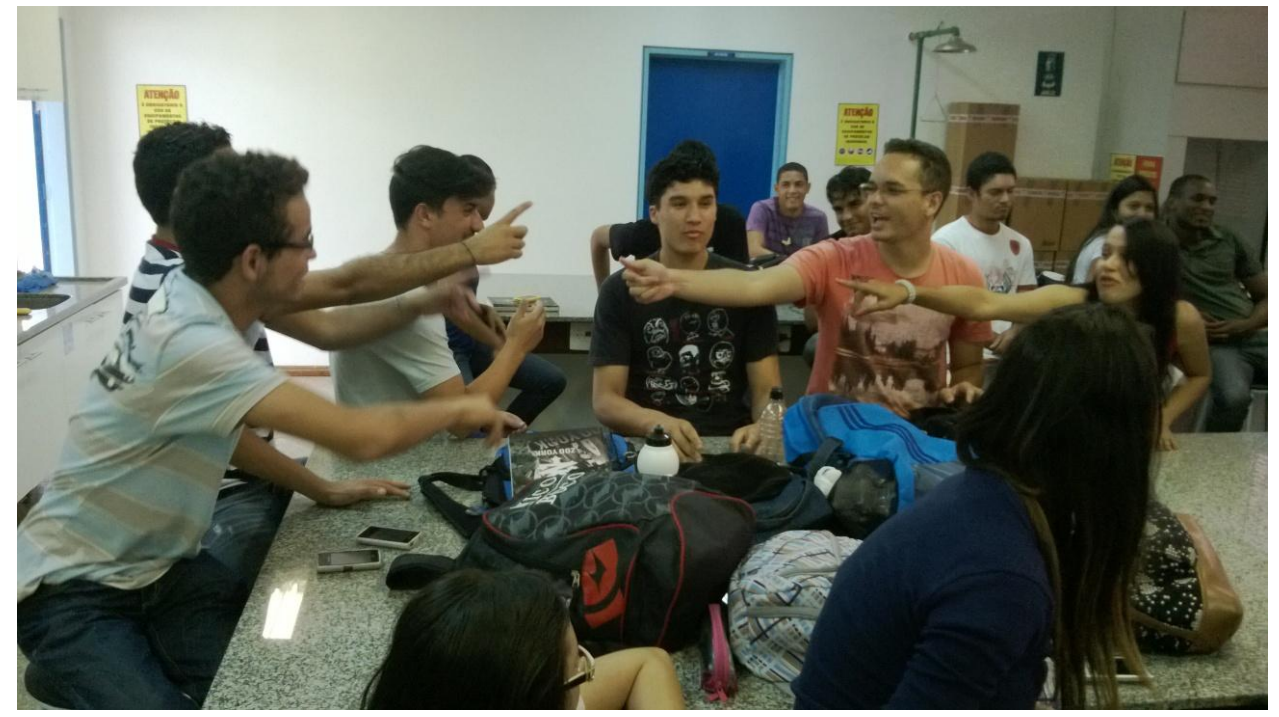

Figura 30 - Interação do grupo. 


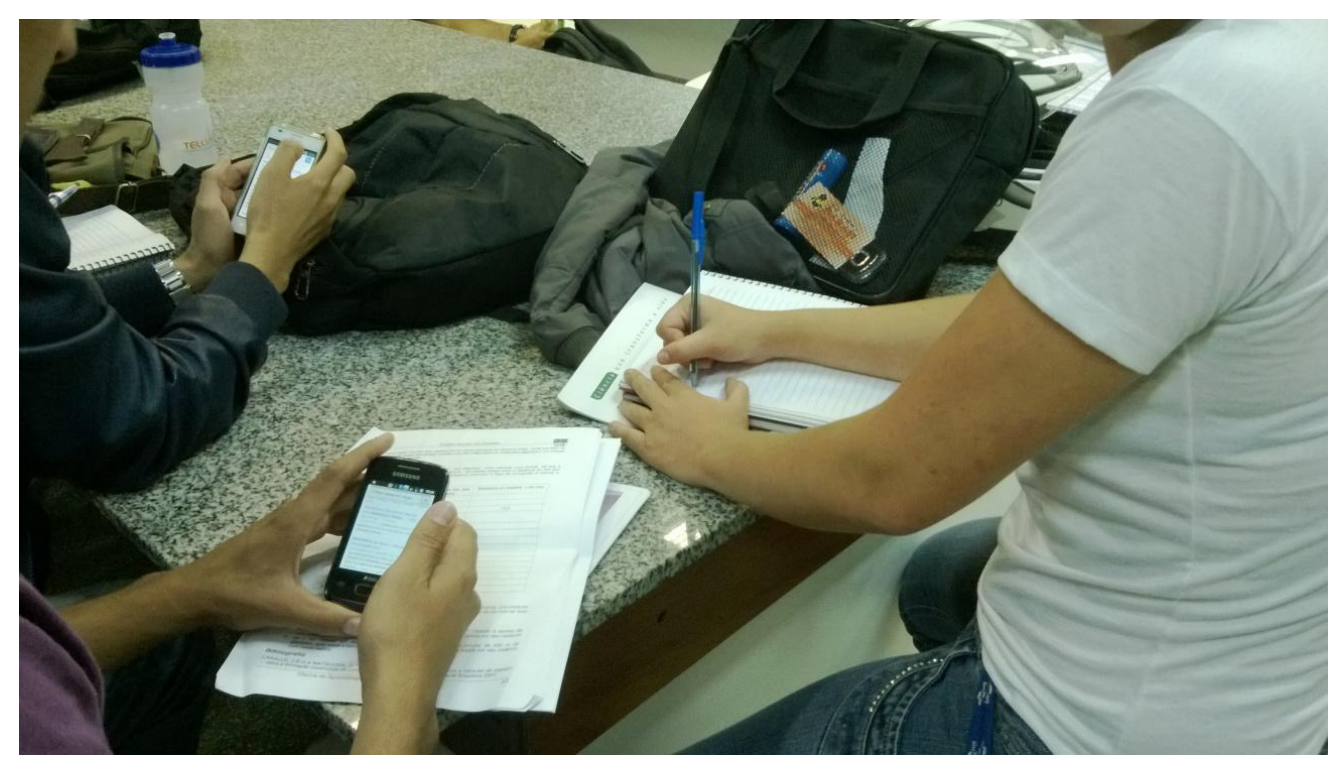

Figura 31 - Busca de informações em diferentes recursos (internet via celular e anotações de aula).

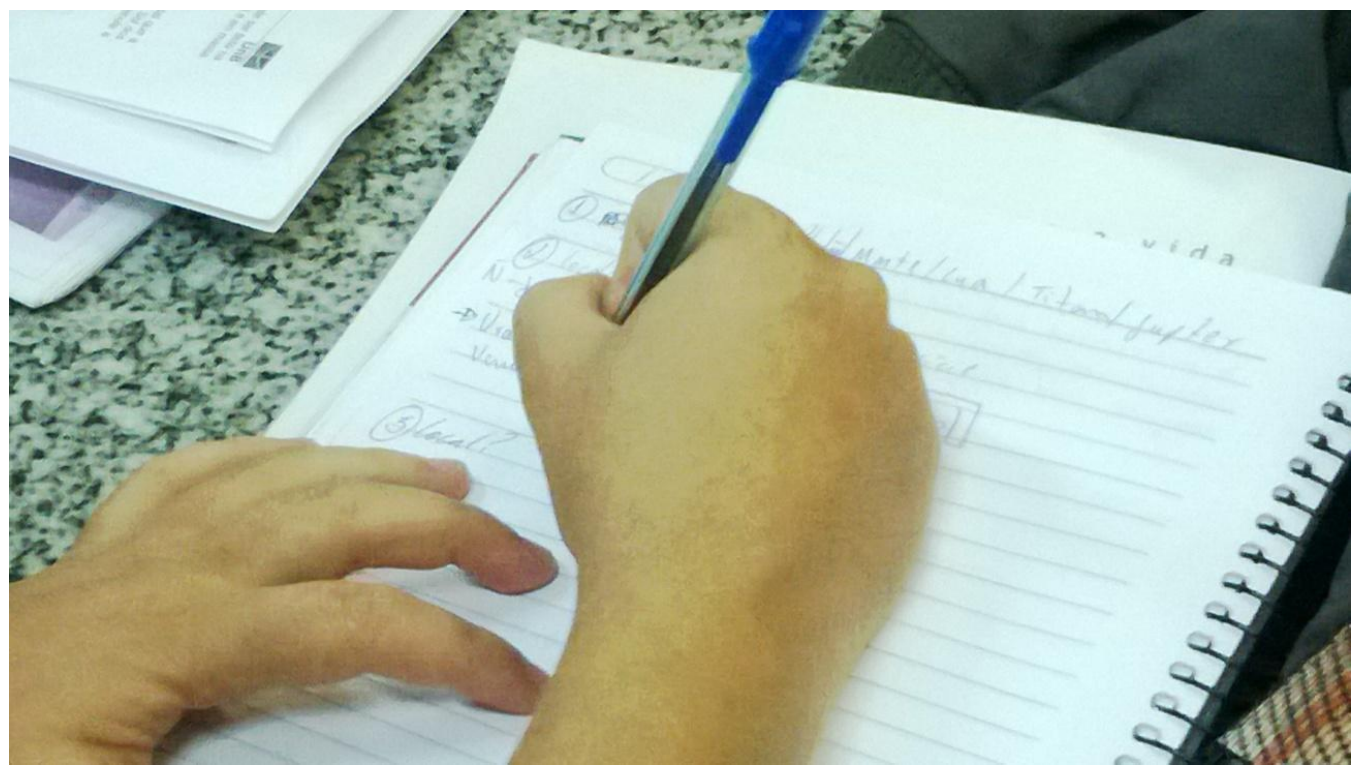

Figura 32 - Registros das informações das dicas das cartas.

Algumas atitudes foram vistas quando, por exemplo, um aluno dizia que olharia no céu o planeta e a estrela com que brincara no Jogo. Os registros escritos durante a aplicação do Jogo Perfil Astronômico, analisados a partir da tabela 2, mostra-nos que 
conteúdos atitudinais e procedimentais foram desenvolvidos. Ficou evidente o desenvolvimento de atitude e procedimento em relação à ciência. Mas, em específico, de acordo com os tópicos da tabela 3, os ocorridos na aplicação do Jogo Perfil Astronômico serão colocados a seguir:

- um aluno desenvolveu uma atitude em relação à ciência quando diferenciou um discurso científico de outros discursos, no momento em que diz que entendeu o que é Astronomia e que vai procurar ver a diferença em relação a outras disciplinas;

- outro aluno teve uma atitude crítica e reflexiva expressa pela pergunta: "Sempre existiu esta fase da estrela? Isto existe?";

- pode ter tido uma visão histórica e relativista que foi significada quando disse que conseguiu construir conceitos e que a Astronomia teve uma história;

- outro estudante desenvolveu uma forma de fazer perguntas investigativas quando perguntou para o aplicador sobre um instrumento da Astronomia e para que ele servia.

A partir da nossa análise, ainda com relação aos conteúdos atitudinais, alguns alunos:

- diferenciaram a abordagem científica de outras abordagens quando perceberam que "o Jogo nos ensina Astronomia";

- desenvolveram gosto pelo rigor e precisão no trabalho, evidenciada pela busca de informações da ciência, e um aluno escreveu no questionário: "Aprendi a buscar mais informações para não ficar com dúvidas";

- desenvolveram uma atitude em relação ao papel social da ciência quando desenvolveram a cooperação que foi vista quando auxiliaram o colega de classe a pensar na resposta e concluíram juntos o que iriam responder (houve a participação do grupo). Uma fala de um dos alunos que foi observada na transcrição da gravação: "O raciocínio e a troca de conhecimento pode ajudar” também enfatiza esta atitude;

- formularam uma discussão crítica da aplicação da ciência na sociedade dizendo: "Aprendi sobre o planeta onde vivo e seus funcionamentos, e instrumentos e sistema planetário são significativos". Referente a este tópico, outro estudante afirmou que "o Universo é vasto e eu não sabia"; 
- desenvolveram uma atitude em relação à aprendizagem da ciência quando: tiveram um enfoque superficial (repetitivo), dizendo que aprenderam os nomes das quatro luas de Júpiter e os disseram;

- tiveram um enfoque profundo (busca de significado) ao dizer: "Vou estudar mais a respeito", "Tive que lembrar o que sabia" e "Vou buscar mais informações".

Os conteúdos procedimentais, em que se pode perceber o que o aluno demonstra em relação à aquisição, interpretação, análise e comunicação da informação, foram percebidos. Foi feita uma análise neste trabalho que mostra algumas formas de demonstrar conteúdos procedimentais que foram vistas na aplicação do Jogo, e foi preciso retomar a parte da tabela 2 (tabela 4), pois esta análise foi realizada a partir dela.

Tabela 4 - Conteúdos procedimentais

\begin{tabular}{|c|c|}
\hline \multirow{4}{*}{ Aquisição da informação } & Observação \\
\hline & Seleção de informação \\
\hline & Busca e captação da informação \\
\hline & Revisão e memorização da informação \\
\hline \multirow{3}{*}{ Interpretação da informação } & Modelagem \\
\hline & Decodificação ou tradução da \\
\hline & informação \\
\hline \multirow{4}{*}{$\begin{array}{l}\text { Análise da informação e } \\
\text { realização de inferências }\end{array}$} & Análise e comparação da informação \\
\hline & Estratégias de raciocínio \\
\hline & Atividades de investigação ou solução de \\
\hline & problemas \\
\hline \multirow{3}{*}{$\begin{array}{l}\text { Compreensão e organização } \\
\text { conceitual da informação }\end{array}$} & Compreensão do discurso (escrito/oral) \\
\hline & Estabelecimento de relações conceituais \\
\hline & Organização conceitual \\
\hline \multirow{3}{*}{ Comunicação da informação } & Expressão oral \\
\hline & Expressão escrita \\
\hline & Outros tipos de expressão \\
\hline
\end{tabular}

No que concerne aos conteúdos procedimentais: 
- um estudante desenvolveu um procedimento em relação à aquisição da informação quando disse que agora conseguiria observar mais o céu, lembrando sobre o que aprendera;

- outros alunos selecionaram as informações que foram importantes e de bons canais de informação para estudar um tema (alunos buscaram informações na internet enquanto jogavam e também em materiais que o professor da disciplina tinha fornecido);

- outro estudante buscou e captou uma informação sobre determinada estrela, perguntando, ouvindo e anotando sobre ela enquanto o professor dizia as dicas;

- outro aluno teve a atitude de revisar e memorizar uma informação enquanto jogava, buscando o conhecimento que já sabia e relacionando-o com o novo conhecimento e isto é demonstrado quando um aluno diz que "Pelas dicas, se estimula o raciocínio e o que já sabemos" e "Inserindo o que já sei, o que já existe, aprendi”.

Neste panorama dos conteúdos procedimentais:

- um aluno desenvolveu um procedimento em relação à interpretação da informação quando modelou a informação que lhe foi transmitida, como a relação entre os tamanhos dos planetas, comparando uns em relação aos outros e isto fica claro quando uma aluna diz: "Não sabia que este planeta era maior, mas agora aprendi";

- outro aluno traduziu a informação para um colega que não havia percebido a diferença entre locais e instrumentos;

- um aluno desenvolveu um procedimento em relação à análise da informação e realização de inferências quando comparou os anos de nascimento de dois cientistas que apareceram no Jogo e perguntou para o colega se eles estavam vivos na mesma época;

- outro estudante demonstrou estratégias de raciocínio quando disse que pode olhar para o céu para ver o planeta Vênus;

- Alunos propuseram atividades de investigação ou solução de problemas dizendo: "Vou olhar para o céu" e "Com este Jogo dinâmico, criativo, se desperta interesse e curiosidade" e "Aprendi curiosidades do Universo que não tinha visto em sala de aula e vou usar isto"; 
- um aluno desenvolveu um procedimento em relação à compreensão e organização conceitual da informação quando compreendeu características das cartas do Jogo;

- um aluno estabeleceu relações conceituais como o conceito das fases das estrelas e teve organização conceitual, conseguindo lembrar e entender o que já sabia. Uma afirmação que exemplifica este procedimento é: "Com as dicas das cartas, lembramos o que já tínhamos esquecido e aprendemos";

- um aluno se expressou oralmente a respeito da ciência e ficou claro que o Jogo é capaz de ensinar ou propiciar a aprendizagem quando disse: "Aprendi muito, pois não sabia sobre Astronomia”. Em relação a este procedimento, outro aluno disse: "Aprendi praticamente de tudo". O conteúdo procedimental também foi evidenciado quando alguns participantes quiseram explicar o que aprenderam no Jogo nas respostas ao questionário;

- outra aluna conseguiu se expressar de maneira escrita sobre os conteúdos científicos quando explicou o que eram certos corpos celestes e os nomeou, em seu próprio caderno.

Existiram expressões de conteúdos atitudinais, procedimentais e conceituais neste trabalho. É importante que existam maneiras de instigar este tipo de conhecimento, pois ele não é tão visto em sala de aula, como afirmam Pozo e Crespo (2006). 
O desenvolvimento da consciência da criança de si mesma é que irá permitir que sua individualidade criativa possa desabrochar e produzir frutos. No entanto, é preciso ter cuidado com o que a escola oferece de conteúdos e de procedimentos de massificação, que tornam todas as crianças modelo padrão, impedindo o desenvolvimento de sua personalidade total, sua individualidade.

(Eliane Mendes Guimarães) 


\title{
CONClusões E Perspectivas
}

\author{
"Divulgar a ciência - tentar tornar os seus métodos e descobertas \\ acessíveis aos que não são cientistas - é o passo que segue natural e \\ imediatamente. Não explicar a ciência me parece perverso.” \\ (CARL SAGAN, 1996, p.26)
}

O Jogo Perfil Astronômico propõe uma abordagem diferenciada por meio do trabalho de forma lúdica e interdisciplinar da Astronomia. Permite que o estudante conjecture seus pensamentos e busque respostas, e neste contexto podem existir atitudes e procedimentos importantes. Um aluno pode ter novas ideias, entender conceitos e criar, ter atitudes a partir de suas inquietudes e agir segundo seus interesses. A partir de uma carta podem surgir muitas dúvidas, também, e este é o início para um enorme aprendizado. Foram vistas expressões de conteúdos atitudinais, procedimentais e conceituais neste trabalho. $\mathrm{O}$ Jogo Perfil Astronômico pode auxiliar no desenvolvimento destes conteúdos.

O Perfil Astronômico proposto neste trabalho é uma iniciativa para começar a mudar a realidade de professores. Aplicá-lo com a vontade de mudanças, mesmo que em mínima parcela de pessoas quando comparado com a educação no mundo, pode ser o início e é um recurso didático que pode auxiliar no ensino-aprendizagem. "Para promover o crescimento do ser humano há de se ter uma intenção educativa diferente da usual nos conteúdos e na forma de sua aplicação" (COLL, 1996, p.13).

Mas o medo de abandonar o quadro da sala de aula, de mudar a forma tradicional de ensinar não pode ser protagonista nesta introdução de um novo recurso. Soares (2008) diz que "ao aplicar atividade lúdica em sala de aula, é interessante que o professor estude mais. A dinâmica dos jogos exige um nível maior de conhecimento, já que se abandona o quadro e se explicita a ideia dos alunos" (p.160).

Os alunos podem ver o professor como auxiliador das regras do jogo, como um mediador do conhecimento, de fato. Então, os alunos se divertem, tem a 
possibilidade de diminuir as barreiras entre professor e aluno, e ocorre o ensinoaprendizagem de forma prazerosa.

Atitudes e procedimentos, assim como conceitos foram vistos durante a aplicação do Jogo. Um aluno dizendo que vai olhar para o céu, perceber as estrelas e planetas e comparar os tamanhos dos corpos celestes, dentre outras afirmações que foram citadas na pesquisa, é uma resposta adequada aos objetivos do trabalho. Sugere o desenvolvimento de atitude e de procedimento quando o Jogo é desenvolvido.

A aplicação do Jogo também pode amenizar a ideia de que brincar é ação de criança e trabalhar é de adulto, como se o trabalho não pudesse ser alegre. Ainda hoje vê-se esta ideia, mas quando o professor e alunos se divertem e aprendem juntos, amenizam este conceito que a sociedade ainda imprime. Sobre este mesmo parecer, Soares (2008) afirma que a relação de professor-aluno é melhorada pelo fato de ambos se divertirem conjuntamente, o que desencadeia um início do processo de desadultificação.

Outro ponto a ser lembrado é que, nas aplicações que foram feitas, viu-se que os alunos se mostraram cooperativos entre si, auxiliaram-se a pensar e prestaram bastante atenção ao que o professor dizia, mostrando interesse. "Os jogos, pela sua própria natureza intrínseca, além de suas características particulares, trazem de volta a disciplina, a atenção, a interação e principalmente o interesse" (SOARES, 2008, p.162).

No que concerne ao Jogo Perfil Astronômico, faz-se necessário dizer que quase a totalidade dos alunos participantes, nas aplicações feitas nas turmas da disciplina 'Universo', considerou o jogo como importante caminho para a aprendizagem. Disseram que o Jogo foi motivador para aprender mais acerca de Astronomia. Alguns disseram que, em classes, desde a escola primária, costumavam ser passivos nas aulas, mas quando o Jogo apareceu (e muitos nunca tinham participado de um em um ambiente escolar), tiveram que agir, que se esforçar para pensar, puderam aprender novos conceitos. Entende-se esta ansiedade, por ser uma novidade para eles. Alguns participantes do Jogo mostraram atitudes para procurar sobre o tema de Astronomia e inclusive alguns disseram que pensam diferente, agora.

No caso do Jogo Perfil Astronômico, vários pensamentos podem repercutir a partir da mesma carta deste Jogo. O pensar não é medido e nem mandado, todavia pode ser investido para que surja e seja direcionado. Com as cartas, que têm suas vinte dicas, vinte possibilidades, vinte formas de começar, assim como incontáveis maneiras de inspirar o pensar, é possível despertar as curiosidades, as atitudes, o pensamento 
individual e em grupo. Para se construir um pensamento, é preciso um conjunto de vivências e diversos saberes, mas esta série de aprendizagens efetivas precisou de um início, uma inspiração para começar. Com este Jogo, é possível relacionar o novo conhecimento com o conhecimento prévio, e é evidente a autonomia do aluno na hora do jogar e seu pensar e construção do próprio conhecimento. É percebida a colaboração entre os estudantes e, embora seja jogo, quase não se desenvolve a competição, porque é muito necessário cooperar. Vê-se o auxílio entre os participantes. Também é evidenciada e favorecida a construção de ideias mais do que a memorização.

O Jogo Perfil Astronômico pode ser encarado como um começo que pode despertar diversas possibilidades de agir e entender o contexto ao seu redor. No desenvolver de uma pessoa, cabe afirmar que não bastou apenas uma vez, não bastou apenas um motivador para o pensar, mas vários, diversos momentos inéditos da construção de pensamentos.

Participar do momento da aplicação do Jogo pode ser entendido como uma etapa que somará com a estrutura de aprendizagem, de conceitos, de atitudes, de procedimentos de um ser humano. Cada aplicação, realizada por um mediador diferente, a cada vez, pode despertar um novo entender, um diferente compreender para o participante. Os estudantes que participaram desta pesquisa, futuros professores de Ciências, entenderam ser importante aplicar este Jogo para alunos do ensino fundamental, pois é possível aprender e se divertir no momento da aplicação. No somatório de pessoas que são instigadas a pensar diferente, alguma mudança pode ser expressa.

As aulas se tornam mais dinâmicas com o jogo, além de auxiliarem o professor no ensino e divertirem os alunos. Mas cabe lembrar que, da mesma forma que aulas em laboratórios e saídas de campo, os jogos não irão resolver todas as dificuldades do sistema de ensino. O sistema escolar necessita de mais mudanças, porém o jogo é uma proposta que pode fazer parte desta mudança. Uma escola bem estruturada ou salários maiores seriam a solução? Talvez sim. Uma estrutura familiar bem desenvolvida ou educação na sociedade fariam da escola um ambiente ideal? Talvez sim. O que se sabe é que é possível fazer nossa parte agora, começando com um experimento, uma saída de campo, entre outros inúmeros recursos, como o Jogo Perfil Astronômico. 


\section{REFERÊNCIAS BIBLIOGRÁFICAS}

ALMEIDA, P. N., Educação lúdica. Técnica e Jogos Pedagógicos. 6 edição, Edições Loyola, 1990.

AUSUBEL, D., Aquisição e retenção de conhecimentos: Uma perspectiva cognitiva Editora Plátano, 2003.

BACHELARD, G. A., Formação do Espírito Científico. Rio de Janeiro: Contraponto, 1996.

BAUER, M. W.; GASKELL, G., 2000; Pesquisa qualitativa com texto, imagem e som. v.9. Rio de Janeiro.

BITTENCOURT, R. N., O lúdico para questionar, Filosofia, ciência e vida. Ano IV, edição 82, maio de 2013.

BORGES, G. L. A., Formação de professores de biologia, material didático e conhecimento escolar,. Campinas-SP, 2000.

BRETONES, P.S.; MEGID NETO, J., Tendências de Teses e Dissertações sobre Educação em Astronomia no Brasil. Boletim da Sociedade Astronômica Brasileira. v. 24, n. 2, p. 35-43, 2005.

BRETONES, P. S., A Astronomia na formação continuada de professores e o papel da racionalidade prática para o tema da observação do céu, Campinas-SP, 2006.

BRETONES, Paulo Sérgio \& COMPIANI, Maurício. A observação do céu como ponto de partida e eixo central em curso de formação continuada de professores. Ensaio Pesquisa em Educação em Ciências, América do Norte, 2010.

BRETONES, P. S. (org.), Jogos para o Ensino de Astronomia. Campinas, SP: Editora Átomo, 2013. 
BRETONES, P. S. (org.), Jogos para o Ensino de Astronomia. 2. ed. Campinas: Átomo, 2014.

CAMPAGNOLO, J. C. N., O Caráter Incentivador das Olimpíadas de Conhecimento: Uma Análise Sobre a Visão dos Alunos da Olimpíada Brasileira de Astronomia e Astronáutica Sobre a Olimpíada. Paraná, 2011.

CARVALHO, E. A., Saberes complexos e educação transdisciplinar. Educ. rev. [online]. 2008, n.32, pp. 17-27. ISSN 0104-4060. http://dx.doi.org/10.1590/S010440602008000200003.

CONCEIÇÃO, M. J., Ciência além dos cálculos, Rev. Bras. Anestesiol. [online]. 2011, vol.61, n.3, pp. 274-274. ISSN 0034-7094. http://dx.doi.org/10.1590/S003470942011000300001. Acessado dia 21/06/13

COOL, César. Psicologia e Currículo - uma aproximação psicopedagógica à elaboração do currículo escolar. 4ed. Trad. Cláudia Schiling. São Paulo: Ática, 1996.

DAMIANI, M. F., 2008. Entendendo o trabalho colaborativo em educação e revelando seus benefícios. Curitiba.

FRISON, M.; VIANNA, J.; CHAVES, J.; BERNARDI, F., 2009. Livro Didático como instrumento de apoio para construção de propostas de ensino de Ciências Naturais. Rio Grande do Sul.

FROMBERG, D.; "Syntax model games and language in early education". Jounal Psycholinguistic Research, 5 (3): 245, 1976.

HUIZINGA, J. Homo Ludens, $4^{\circ}$ edição, Editora Perspectiva, São Paulo, 2000.

IVANISSEVICH, A.; WUENSCHE, C.; ROCHA, J. (orgs.) Astronomia Hoje. Rio de Janeiro: Instituto Ciência Hoje, 2010.

KISHIMOTO, T. M. O Jogo e a educação infantil. IN: Jogo, Brinquedo, Brincadeira e a Educação. KISHIMOTO, T. M. (org). São Paulo, Cortez Editora, 4ª Edição, 1996. 
LANGHI, R., NARDI, R., Ensino da Astronomia no Brasil: educação formal, informal, não formal e divulgação científica. Revista Brasileira de Ensino de Física, v. 31, n. 4, 4402. 2009.

LEÃO, D. Dissertação Astronomia no ensino médio: Um Mini-planetário como recurso instrucional para compreensão da dinâmica celeste. 2012. Brasília.

LEITE. C, Os professores de Ciências e sua Formas de Pensar Astronomia. 2002. Dissertação (Mestrado) - Universidade de São Paulo (USP), São Paulo.

LEITE, C., HOSOUME, Y., Explorando a dimensão espacial na pesquisa em ensino de Astronomia. REEC. Revista Electrónica de Enseñanza de las Ciencias, v. 8, p. 797$811,2009$.

LERNER, M. Uma avaliação da utilização de jogos em educação. Rio de Janeiro: COPPE/UFRJ, 1991. (Oficinas de informática na Educação)

LOPES, M. da G. Jogos na Educação: criar, fazer e jogar. 4a . Ed. Revista. São Paulo: Cortez, 2001.

MARTINEZ, I. G. KIT-ASTRONOMIA Um recurso didático para inserção das ciências no ensino básico, 2011.

MIRANDA, S., Do fascínio do jogo à alegria do aprender nas séries iniciais ,Campinas, SP: Papirus, 2001.

MORENO, M. F. O ensino e a divulgação da Astronomia. Disponível em: <http://pessoal.utfpr.edu.br/oscarsantos/?id=4>. Acesso em: 5 de maio, 2014.

MOURÃO, R. R. de F., Dicionário enciclopédico de Astronomia e Astronáutica. $2^{\mathrm{a}}$ edição. Rio de Janeiro, Lexikon Editora Digital, 2008.

OLIVEIRA, R. S., Astronomia no ensino fundamental. disponível em < http://www.asterdomus.com.br/Artigo_Astronomia_no_ensino_fundamental.htm > publicado em 1997. Acesso em agosto de 2012. 
OSTERMANN, F.\& CAVALCANTI, C. J. H. Roteiro para Construção de um Planejamento de uma Unidade Didática. Teorias de Aprendizagem no Ensino de Física. Rio Grande do Sul, 2010.

PERRENOUD, P. Construir as competências desde a escola. Editora Artmed: Porto Alegre, 1999.

PIAGET, Jean. A formação do símbolo na criança: Imitação, jogo e sonho, imagem e representação, 1971.

POZO, Juan Ignácio \& CRESPO, Miguel. A aprendizagem e o ensino de Ciências, do Conhecimento cotidiano ao Conhecimento científico, 2006.

PROJETO POLÍTICO PEDAGÓGICO DO CURSO DE LICENCIATURA EM CIÊNCIAS, UnB, 2010

QUINTANILHA, E. C. Fascínio do Universo, 2002. Dissertação de Mestrado, Universidade Brasília, Brasília - DF.

RETONDAR, J. J. M., Teoria do jogo: a dimensão lúdica da existência humana. Petrópolis: Vozes, 2007.

RIZZO, G. Jogos inteligentes: a construção do raciocínio na escola natural. Rio de Janeiro: Bertrand Brasil, 1996.

SAGAN, C. O mundo assombrado pelos demônios - a ciência vista como uma vela no escuro. São Paulo: Cia das Letras, 1996.

SAMPAIO, M. M. F.,; RIBEIRO, M. J. R., Coerência entre avaliação e organização curricular. In:Ensinar e aprender: reflexões e criação. v. 3. São Paulo: CENPEC, 1998. SOARES, M. Jogos para o ensino de Química: teoria, métodos e aplicações. GuarapariES. Ex Libris, 2008.

STRAUSS, Anselm; CORBIN, Juliet., 2008; Pesquisa qualitativa: Técnicas e procedimentos para o desenvolvimento de teoria fundamentada. v.2. São Paulo. 
TREVISAN, S. D. et al. Astro-jogos: uma forma divertida de aprender Astronomia.

Boletim da Sociedade Astronômica Brasileira, v.28, p.106, 2008.

VYGOTSKY, L. S. Pensamento e linguagem. São Paulo: Martins Fontes, 1989. 


\section{ANEXOS}

\section{AneXo A - Questionário de Avaliação do Jogo}

1. Em qual semestre e ano você ingressou no curso de licenciatura em Ciências Naturais?

2. No que diz respeito ao Jogo Perfil Astronômico, cite suas vantagens para ser usado em sala de aula, pelos professores de Ensino Fundamental (pode escolher quantas alternativas for preciso).

a) Favorece o raciocínio lógico.

b) Possibilita construção de conhecimentos.

c) Gera interação.

d) Gera competitividade.

e) Possibilita a participação.

f) Faz parecer que o tempo passa rápido.

g) Possibilita a fixação de conhecimento.

h) Possibilita aprender sobre Astronomia.

i) Possibilita aprender sobre outros conteúdos. Especificar:

j) Possibilita aprender sobre corpos celestes.

1) Possibilita aprender sobre cientistas.

m) Possibilita aprender sobre instrumentos da Astronomia.

n) Possibilita aprender sobre fenômenos e acontecimentos da Astronomia.

o) Faz lembrar conhecimentos já aprendidos.

p) Possibilita a interação do que está sendo aprendido com conhecimentos já aprendidos.

q) Possibilita a interação entre os alunos.

r) Possibilita a interação entre alunos e professor.

s) Gera uma relação entre o professor e aluno, sem espaço para inferioridade.

t) Possibilita o compartilhamento dos conhecimentos dos alunos.

u) Desperta a curiosidade. 
v) Desperta a curiosidade para que o aluno busque mais informações em outros lugares.

x) Possibilita a memorização.

z) Outros (especificar):

3. No que diz respeito ao Jogo Perfil Astronômico, cite suas desvantagens para ser usado em sala de aula, pelos professores de Ensino Fundamental (pode escolher quantas alternativas for preciso).

a) Não favorece o raciocínio lógico.

b) Não possibilita construção de conhecimentos.

c) Não gera interação.

d) Gera competitividade exagerada.

e) Não possibilita a participação.

f) Não é possível aprender.

g) Não possibilita a fixação de conhecimento.

h) Apenas faz memorizar os conceitos do jogo.

i) Não possibilita a interação de conceitos.

j) Não possibilita aprender sobre corpos celestes.

1) Não possibilita aprender sobre cientistas.

m) Não possibilita aprender sobre instrumentos da Astronomia.

n) Não possibilita aprender sobre fenômenos e acontecimentos da Astronomia.

o) Não há espaço para demonstrar o que já sabe.

p) Não possibilita a interação do que está sendo aprendido com conhecimentos já aprendidos.

q) Não possibilita a interação entre os alunos.

r) Não possibilita a interação entre alunos e professor.

s) Não é divertido.

t) Não possibilita o compartilhamento dos conhecimentos dos alunos.

u) Não desperta a curiosidade.

v) Não desperta a curiosidade para que o aluno busque mais informações em outros lugares.

x) Não é dinâmico.

z) Outros (especificar):

4. Você aprendeu com o Jogo Perfil astronômico? 
( ) Sim ( ) Não

4.1 Se sim, O que você aprendeu ?

4.2 Se sim, como você aprendeu?

5. Que restrição, em termos de material ou características do Jogo, você faria?

6. O que você acha que pode ser melhorado no Jogo?

7. Depois de formado em licenciatura em Ciências Naturais, você experimentaria aplicar jogos ao longo das suas aulas? Por quê?

8. Você considera importante que os estudantes do ensino fundamental e médio aprendam a respeito do tema Astronomia? Por quê? 


\section{Anexo B - Termo de Consentimento Livre E Esclarecido}

Convido o (a) Senhor (a)

participar da pesquisa “ $O$ desenvolvimento do pensamento científico utilizando um jogo sobre Astronomia", que tem o objetivo de verificar os conteúdos que o Jogo Perfil Astronômico possibilita para o desenvolvimento do pensamento científico. Depois será criada uma Unidade didática e se necessário, o Jogo será modificado e acrescentado de novas cartas, para o uso de professores.

Este trabalho será direcionado pela mestranda Isabella Guedes Martinez, do Programa de Pós-Graduação em Ensino de Ciências da Universidade de Brasília, sob a orientação da Professora Dra. Eliane Mendes Guimarães, em co-orientação do Professor Dr. Ivan Soares Ferreira.

Não haverá risco físico ou mental; Os contatos serão possíveis por meio de telefones ou emails; O trabalho será de grande valia para o contexto científico; Este trabalho ficará disponível para acessos.

Nome / assinatura

Isabella Guedes Martinez

Mestranda Responsável

Brasília, de de 